\title{
Getting to Know GIMF: The Simulation Properties of the Global Integrated Monetary and Fiscal Model
}

Derek Anderson, Benjamin Hunt, Mika Kortelainen, Michael Kumhof, Douglas Laxton, Dirk Muir, Susanna Mursula, and Stephen Snudden 


\title{
IMF Working Paper
}

\author{
Research Department
}

\section{Getting to Know GIMF: The Simulation Properties of the Global Integrated Monetary and Fiscal Model

\author{
Prepared by Derek Anderson, Benjamin Hunt, Mika Kortelainen, Michael Kumhof, \\ Douglas Laxton, Dirk Muir, Susanna Mursula, and Stephen Snudden
}

February 2013

\begin{abstract}
:
The Global Integrated Monetary and Fiscal model (GIMF) is a multi-region, forward-looking, DSGE model developed by the Economic Modeling Division of the IMF for policy analysis and international economic research. Using a 5-region version of the GIMF, this paper illustrates the model's macroeconomic properties by presenting its responses under a wide range of experiments, including fiscal, monetary, financial, demand, supply, and international shocks.

JEL Classification Numbers: D58, E27, E37, E52, E62, E63, F41, F47, H60

Keywords: business cycle, fiscal multipliers; fiscal consolidation; fiscal policy; general equilibrium models, interest rates, macroeconomic interdependence, monetary policy, policy effects, simulation.

Authors' E-Mail Addresses: danderson2@imf.org; bhunt@imf.org; mika.kortelainen@bof.fi; mkumhof@imf.org; dlaxton@imf.org; dmuir@imf.org; smursula@imf.org; ssnudden@imf.org

This Working Paper should not be reported as representing the views of the IMF.

The views expressed in this Working Paper are those of the author(s) and do not necessarily represent those of the IMF or IMF policy. Working Papers describe research in progress by the author(s) and are published to elicit comments and to further debate.
\end{abstract}




\section{Contents}

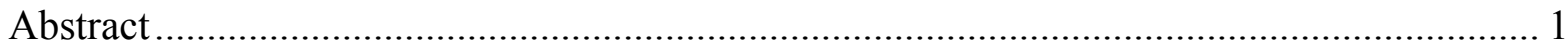

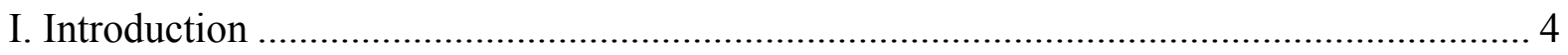

II. Summary of the Global Integrated Monetary and Fiscal Model (GIMF) ......................... 4

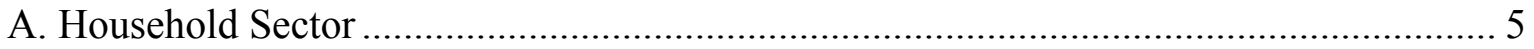

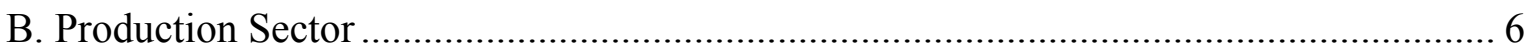

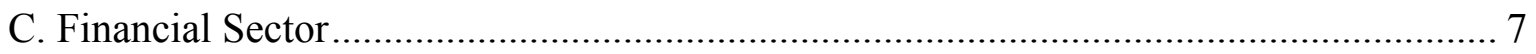

D. International Dimensions and Spillovers ............................................................. 7

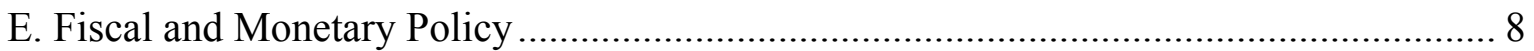

III. Properties of Fiscal Shocks ............................................................................................ 9

A. Fiscal Multipliers Based on 2 Years of Fiscal Stimulus .......................................... 9

Two Year Increase in Government Spending - Consumption versus Investment .......... 9

Two Year Increase in Lumpsum Transfers - General versus Targeted to LIQ

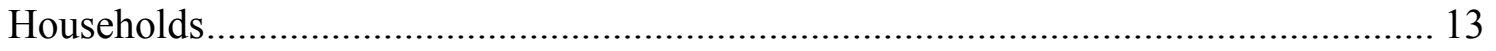

Two Year Decrease in Taxation .......................................................................... 15

B. Permanent Fiscal Consolidation......................................................................... 18

Permanent Fiscal Consolidation through Government Spending - Consumption versus

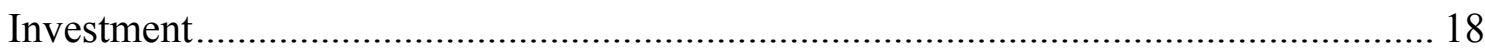

Permanent Fiscal Consolidation through Lumpsum Transfers - General versus Targeted

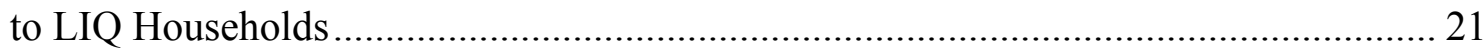

Permanent Fiscal Consolidation through Increased Taxation .................................. 25

C. Permanent Fiscal Consolidation and the Issue of Credibility .................................. 28

IV. Properties of Financial and Monetary Shocks ........................................................... 31

A. Temporary Increase in the Nominal Interest Rate ................................................... 32

B. Temporary but Persistent Increase in Borrowers' Riskiness ................................... 35

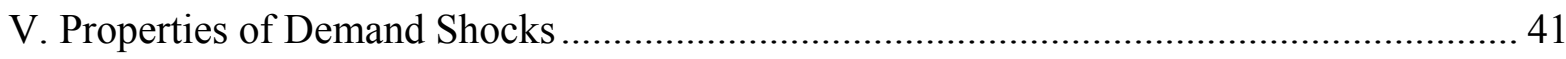

A. Temporary Increase in Private Domestic Demand .................................................. 41

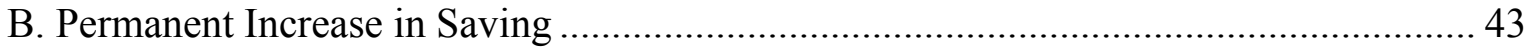

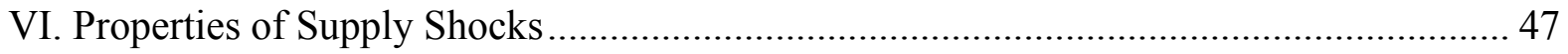

A. Permanent Increase in the Level of Labor-Augmenting Productivity in Intermediate Goods Production, and the Balassa-Samuelsson Effect ............................................ 47

B. Temporary 10-Year Increase in the Growth Rate of Labor-Augmenting Productivity in All Intermediate Goods Production ........................................................................ 51 
C. Permanent Increase in Competition in the Labor Market that Decreases the Markup in Real Wages 55

D. Permanent Increase in Competition that Decreases Intermediate Goods Price Markups 57

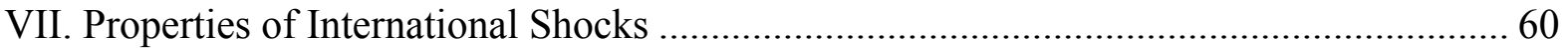

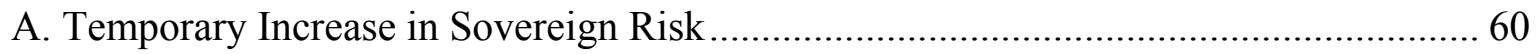

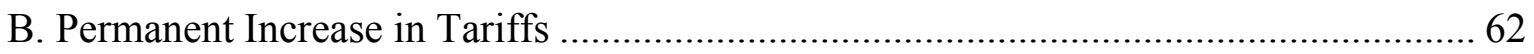

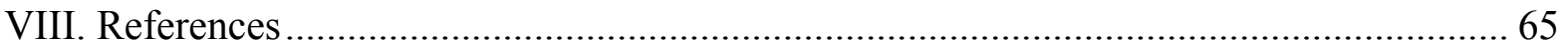




\section{INTRODUCTION}

This paper documents the simulation properties of the International Monetary Fund's Global Integrated Monetary and Fiscal model (GIMF). The simulations presented are designed to illustrate how the economic theory underlying GIMF's structure, which is outlined in the companion paper, Kumhof and others (2010), translates into macroeconomic behavior.

The properties of the model are illustrated with the response of key macro variables to different shocks that hit the economy. The most salient variables are often real GDP, inflation, interest rates, exchange rates, and current account balances, among others. The focus is on the properties in response to shocks in the United States, and their spillovers to other regions in the world. These properties will hold, in general, in all regions of the world, with some dissimilarities that result from special features in each region (such as the share of liquidity-constrained households, or the pursuit of a fixed nominal exchange rate).

Section II contains a short description of the model, which summarizes Kumhof and others (2010). Sections III through VII explore the outcomes of shocks to different sectors of the model. Section III, by far the largest section, is about fiscal shocks - temporary fiscal stimulus, permanent fiscal consolidation, and permanent fiscal consolidation scenarios that explore the concept of credibility. There are also additional boxes on issues such as monetary accommodation. Section IV discusses monetary policy and financial shocks, including further exploration of the role of the financial accelerator in GIMF. Section V presents shocks to demand. Section VI examines the model's response under shocks to the supply side, mainly productivity, wage, and price markups, as well as the Balassa-Samuelson effect. Finally, Section VII presents shocks of an international nature, such as those to risk premia and tariffs.

\section{SumMARY OF THE GLOBAL INTEGRATEd MONETARY AND FiSCAL MODEL (GIMF) ${ }^{1}$}

GIMF is a multicountry Dynamic Stochastic General Equilibrium (DSGE) model with optimizing behavior by households and firms, and full intertemporal stock-flow accounting. Frictions in the form of sticky prices and wages, real adjustment costs, liquidity-constrained households, along with finite-planning horizons of households, imply an important role for monetary and fiscal policy in economic stabilization.

The assumption of finite horizons separates GIMF from standard monetary DSGE models and allows it to have well-defined steady states where countries can be long-run debtors or creditors. This allows users to study the transition from one steady state to another where

\footnotetext{
${ }^{1}$ For detailed documentation on the structure of the model see Kumhof and others (2010).
} 
fiscal policy and private saving behavior play a critical role in both the dynamics and longrun comparative statics. ${ }^{2}$

The non-Ricardian features of the model provide non-neutrality in both spending-based and revenue-based fiscal measures, which makes the model particularly suitable to analyze fiscal policy questions. In particular, fiscal policy can stimulate the level of economic activity in the short run, but sustained government deficits crowd out private investment and net foreign assets in the long run. ${ }^{3}$ Sustained fiscal deficits in large economies can also lead to a higher world real interest rate, which is endogenous.

Asset markets are incomplete in the model. Government debt is only held domestically, as nominal, non-contingent, one-period bonds denominated in domestic currency. The only assets traded internationally are nominal, non-contingent, one-period bonds denominated in U.S. dollars that can be issued by the U.S. government and by private agents in any region. Firms are owned domestically. Equity is not traded in domestic financial markets; instead, households receive lump-sum dividend payments.

Firms employ capital and labor to produce tradable and nontradable intermediate goods. There is a financial sector a la Bernanke, Gertler and Gilchrist (1999), that incorporates a procyclical financial accelerator, with the cost of external finance facing firms rising with their indebtedness.

GIMF is multi-region, encompassing the entire world economy, explicitly modeling all the bilateral trade flows and their relative prices for each region, including exchange rates. The version used in this paper is comprised of 5 regions: the United States, the euro area, Japan, emerging Asia (including China), and, as a single entity, the remaining countries. The international linkages in the model allow the analysis of policy spillovers at the regional and global level.

\section{A. Household Sector}

There are two types of households, both of which consume goods and supply labor. First, there are overlapping-generation households (OLG) that optimize their borrowing and saving decisions over a 20-year planning horizon. Second, there are liquidity-constrained households (LIQ), who do not save and have no access to credit. Both types of households

\footnotetext{
${ }^{2}$ See Blanchard (1985) for the basic theoretical building blocks and Kumhof and Laxton (2007, 2009b) to understand their fiscal policy implications.

${ }^{3}$ Coenen and others (2010) show that GIMF fiscal multipliers for temporary shocks are similar to standard monetary business cycle models, but more importantly, GIMF can handle a much broader array of permanent shocks that can be used to study transitions from one steady state to another caused by permant changes in the level of government debt.
} 
pay direct taxes on labor income, indirect taxes on consumption spending, and a lump-sum tax.

OLG households save by acquiring domestic government bonds, international U.S. dollar bonds, and through fixed-term deposits. They maximize their utility subject to their budget constraint. Aggregate consumption for these households is a function of financial wealth and the present discounted value of after-tax wage and investment income. The consumption of LIQ households is equal to their current net income, so their marginal propensity to consume out of current income is unity by construction. ${ }^{4}$ A high proportion of LIQ households in the population would imply large fiscal multipliers from temporary changes to taxes and transfer payments.

For OLG households with finite-planning horizons, a tax cut has a short-run positive effect on output. When the cuts are matched with a tax increase in the future, so as to leave government debt unchanged in the long run, the short-run impact remains positive, as the change will tilt the time profile of consumption toward the present. In effect, OLG households discount future tax liabilities at a higher rate than the market rate of interest. Thus, an increase in government debt today represents an increase in their wealth, because a share of the resulting higher taxes in the future is payable beyond their planning horizon. If the increase in government debt is permanent (tax rates are assumed to rise sufficiently in the long run to stabilize the debt-to-GDP ratio by financing the higher interest burden) this will crowd out real private capital by raising real interest rates. ${ }^{5}$

Increases in the interest rate have a negative effect on consumption, mainly through the impact on the value of wealth. The intertemporal substitution effect from interest rate changes is moderate and has been calibrated to be consistent with the empirical evidence. The intertemporal elasticity of substitution determines the magnitude of the long-run crowding-out effects of government debt since it pins down how much real interest rates have to rise to encourage households to provide the required savings.

\section{B. Production Sector}

Firms, which produce tradable and nontradable intermediate goods, are managed in accordance with the preferences of their owners, finitely-lived households. Therefore, firms also have finite-planning horizons. The main substantive implication of this assumption is the presence of a substantial equity premium driven by impatience. ${ }^{6}$ Firms are subject to nominal

\footnotetext{
${ }^{4}$ The liquidity-constrained consumers could also be interpreted more generally as rule-of-thumb consumers, which in other models are assumed to consume all of their income.

${ }^{5}$ For a more detailed description of fiscal implications in GIMF see Kumhof and Laxton (2007, 2009a, 2009b).

${ }^{6}$ This feature would disappear if equity was assumed to be traded in financial markets. We find the assumption of myopic firm behavior, and the resulting equity premium, to be more plausible.
} 
rigidities in price setting as well as real adjustment costs in labor hiring and investment. They pay capital income taxes to governments and wages and dividends to households.

Retained earnings are insufficient to fully finance investment, so firms must borrow from financial intermediaries. If earnings fall below the minimum required to make the contracted interest payments, the financial intermediaries take over the firm's capital stock, less any auditing and bankruptcy costs, and redistribute it back to their depositors (households).

Firms operate in monopolistically competitive markets, and thus goods' prices contain a markup over marginal cost. Exports are priced to the local destination market and imports are subject to quantity adjustment costs. There are also price adjustment costs which lead to sticky prices.

Firms use public infrastructure (which is the government capital stock) as an input, in combination with tradable and nontradable intermediate goods. Therefore, government capital adds to the productivity of the economy.

\section{Financial Sector}

GIMF contains a limited menu of financial assets. Government debt consists of one-period bonds denominated in domestic currency. Banks offer households one-period fixed-term deposits, their source of funds for loans to firms. These financial assets, as well as ownership of firms, are not tradable across borders. OLG households may, however, issue or purchase tradable U.S.-dollar-denominated obligations.

Banks pay a market rate of return on deposits, and charge a risk premium on loans. Because of the costs of bankruptcy (capital can only be liquidated at a discount), the lending rate includes an external financing premium, which varies directly with the debt-to-equity (leverage) ratio - the financial accelerator effect. Non-linearities imply steep increases in the risk premium for large negative shocks to net worth.

Uncovered interest parity does not hold, due to the presence of country risk premiums. The premiums create deviations, both in the short run and the long run, between interest rates in different regions, even after adjustment for expected changes in exchange rates.

\section{International Dimensions and Spillovers}

All bilateral trade flows are explicitly modeled, as are the relative prices for each region, including exchange rates. These flows include the export and import of intermediate and final goods. They are calibrated in the steady state to match the flows observed in the recent data. International linkages are driven by the global saving and investment decisions, a by-product of consumers' finite horizons. This leads to uniquely defined current account balances and net foreign asset positions for each region. Since asset markets are incomplete, net foreign 
asset positions are represented by nominal non-contingent one-period bonds denominated in U.S. dollars.

Along with uncovered interest parity, and long-term movements in the world real interest rate, the magnitude of the international trade linkages is the main determinant of spillover effects from shocks in one region to other regions in the world.

\section{E. Fiscal and Monetary Policy}

Fiscal policy is conducted using a variety of expenditure and tax instruments. Government spending may take the form of either consumption or investment expenditure, or lumpsum transfers to either all households or targeted towards LIQ households. Revenue accrues from the taxes on labor and corporate income, consumption taxes, and lumpsum taxes. The model also allows for tariffs on imported goods to be a potential source of public revenue.

Government investment spending augments public infrastructure, which depreciates at a constant rate over time.

There is a fiscal policy rule which ensures long-run sustainability, while allowing for shortrun counter-cyclical policies. Changes in both labor and capital income taxes provide the instrument to put the rule into effect, but this can be replaced with other tax, transfer or spending instruments if that is considered more realistic for a specific region. First, the fiscal rule ensures that in the long run, the government debt-to-GDP ratio - and hence the deficitto-GDP ratio- eventually converges to its target level. This excludes the possibility of sovereign default, as well as the risk that out-of-control financing requirements of the government will override monetary policy. Second, the rule allows for countercyclical fiscal policy as it embodies automatic stabilizers.

When conducting monetary policy, the central bank uses an inflation-forecast-based interest rate rule. The central bank varies the gap between the actual policy rate and the long-run equilibrium rate to achieve a stable target rate of inflation over time. 


\section{Properties of Fiscal Shocks}

The centerpiece of GIMF is its ability to deal with a wide range of fiscal issues, alone and in tandem with monetary policy. This section presents the model properties related to the seven fiscal instruments in GIMF - government consumption spending, government investment spending, general lumpsum transfers to all households, lumpsum transfers targeted to highmarginal-propensity-to-consume LIQ households, consumption taxes, labor income taxes, and corporate income taxes. The simulation experiments are conducted in the United States block of the model. Under consideration are temporary fiscal stimulus, permanent fiscal consolidation, and fiscal consolidation that accounts for the credibility of fiscal policy.

\section{A. Fiscal Multipliers Based on 2 Years of Fiscal Stimulus}

This subsection presents the effects of temporary fiscal stimulus through each of the seven available fiscal instruments. Moreover, the amplifying effects of monetary accommodation are also presented in Box 1. All of the reported results are in terms of deviation from the steady-state baseline. To maintain the deficit-to-GDP target in the long run, the government adjusts general lumpsum transfers.

\section{Two Year Increase in Government Spending - Consumption versus Investment}

Figure 1 compares the effects of increasing U.S. government spending through either an increase in government consumption or government investment by 1 percentage point of baseline GDP for two years. The increase in government consumption drives up real GDP by less than 1 percent for two years and inflation rises by more than $1 / 4$ percentage point. The same stimulus through government investment drives real GDP up by just over 1 percent after two years, and real GDP stays above baseline for over thirty years, with inflation effects similar to the case of government consumption.

Under both types of stimulus, higher government spending increases aggregate demand directly. Since government goods are assumed to have a domestic and imported component, there are notable effects in both the domestic and external sectors. The increase in demand for final domestic goods increases the demand for domestic labor. Higher labor demand raises wages, increasing marginal costs and thereby driving up the prices of domestically produced goods. In response to rising inflation, the U.S. monetary authority increases the nominal policy interest rate, which flows through to real interest rates. Higher real interest rates increase the cost of capital, dampening private investment demand. Further, for households, higher real interest rates partially offset the impact of higher incomes on consumption expenditure. In addition, the automatic fiscal stabilizers operate such that transfers adjust to dampen private demand.

The increase in real interest rates appreciates the U.S. real effective exchange rate, lowering import prices for U.S. residents and raising the cost of U.S. exports abroad. Lower import 
prices increase U.S. demand for imports from abroad, while higher export prices decrease foreign demand for U.S. goods. The net impact is a temporary deterioration in the current account.

What differentiates an increase in government investment from that of government consumption is the additional stimulative effect of the government capital stock on productivity. ${ }^{7}$ Government investment increases the public capital stock, which raises the general productivity of the economy as a whole, and therefore real GDP. Moreover, this effect lasts longer than a shock to the private business capital stock, as government capital has a much lower depreciation rate (4 percent versus 10 percent), meaning a temporary increase in government investment will raise the economy's productive capacity for many years to come.

The impact on the rest of the world of a two year increase in U.S. government spending through either consumption or investment is presented in Figure 2. The output effect in the rest of the world is roughly one tenth of the magnitude in the United States. This increase in foreign real GDP reflects trade linkages and captures the impact of higher exports to the United States. When government investment is the instrument for fiscal stimulus, it has a slightly larger effect, solely because of the prolonged effects on the U.S. demand for imported goods. However, since this fiscal stimulus is temporary, the spillover effects are relatively small. For the remainder of the section, rest-of-world results will only be included for the permanent stimulus experiments that embody more notable spillover effects.

\footnotetext{
${ }^{7}$ Without this channel, an increase in government investment spending would be virtually indistinguishable from an increase in government consumption spending.
} 
Figure 1:

Temporary Stimulus Through Increased Government Spending (1\% of GDP For 2 Years) Effects in United States

Percent or percentage point deviation from steady-state baseline (Horizontal axis is in years: $L R=$ Long Run)

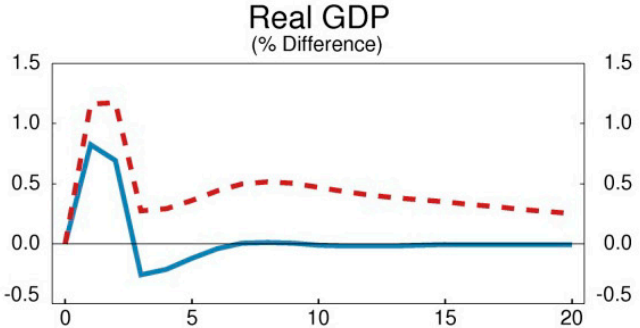

Real Private Consumption

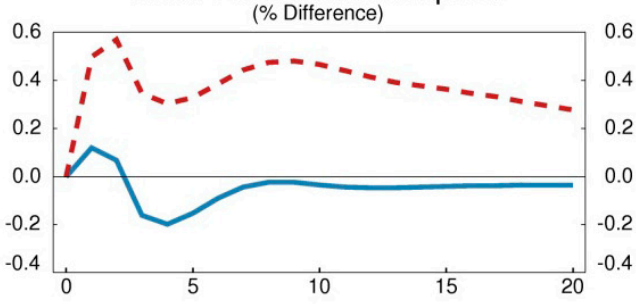

Government Consumption

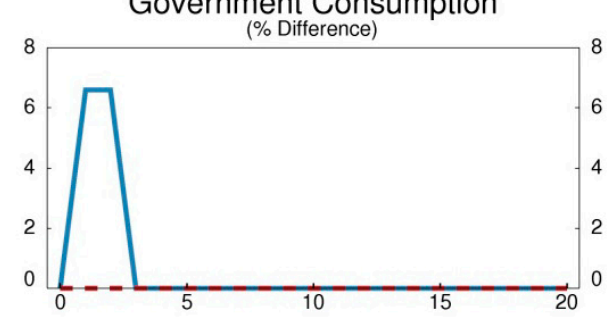

CPI Inflation

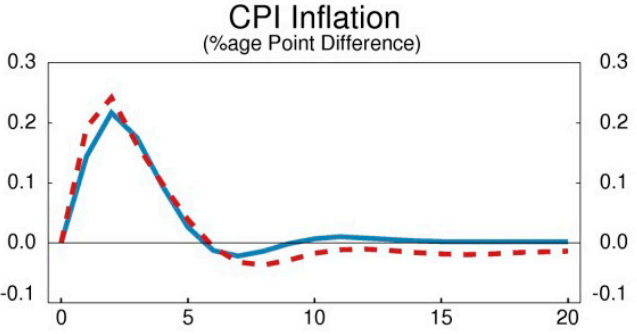

Real Effective Exchange Rate

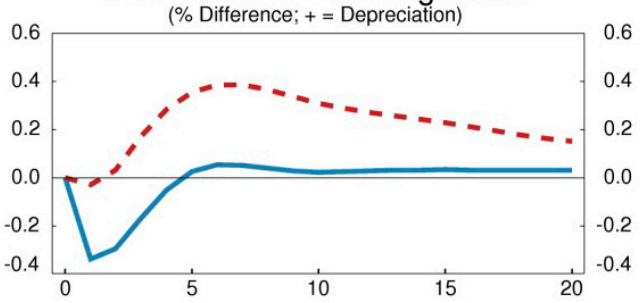

Government Surplus/GDP

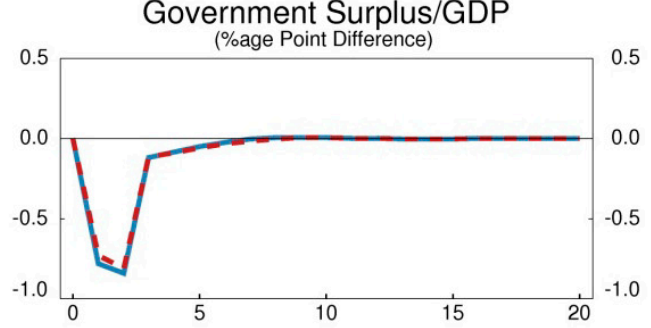

Real Private Investment

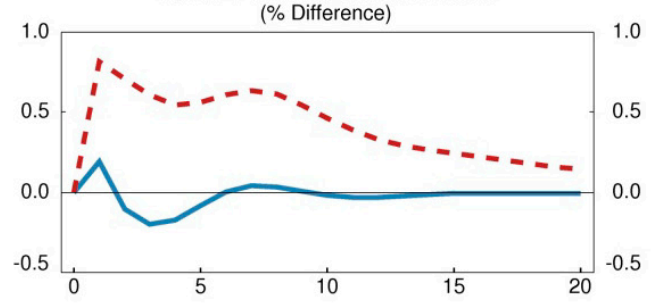

Government Investment
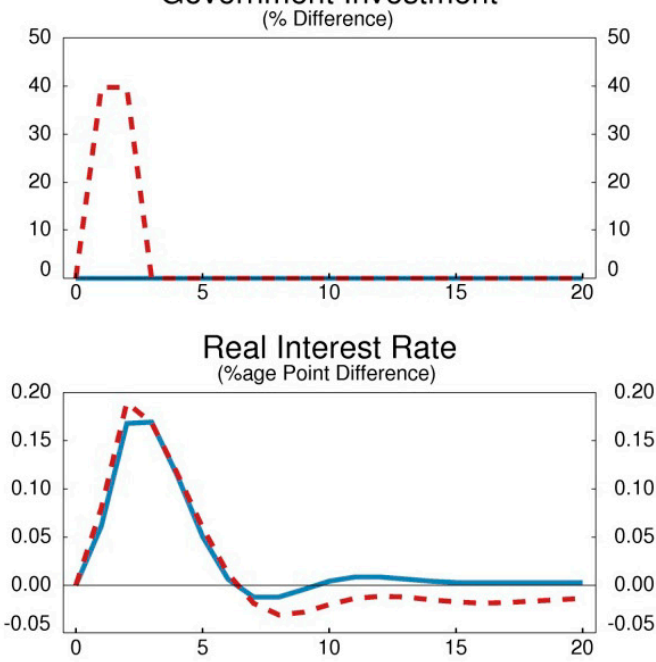

Current Account/GDP

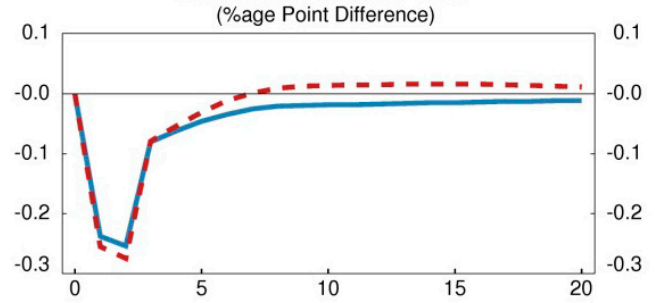


Figure 2:

Temporary Stimulus Through Increased Government Spending (1\% of GDP For 2 Years) Effects in the Rest of the World

Percent or percentage point deviation from steady-state baseline (Horizontal axis is in years: $L R=$ Long Run)
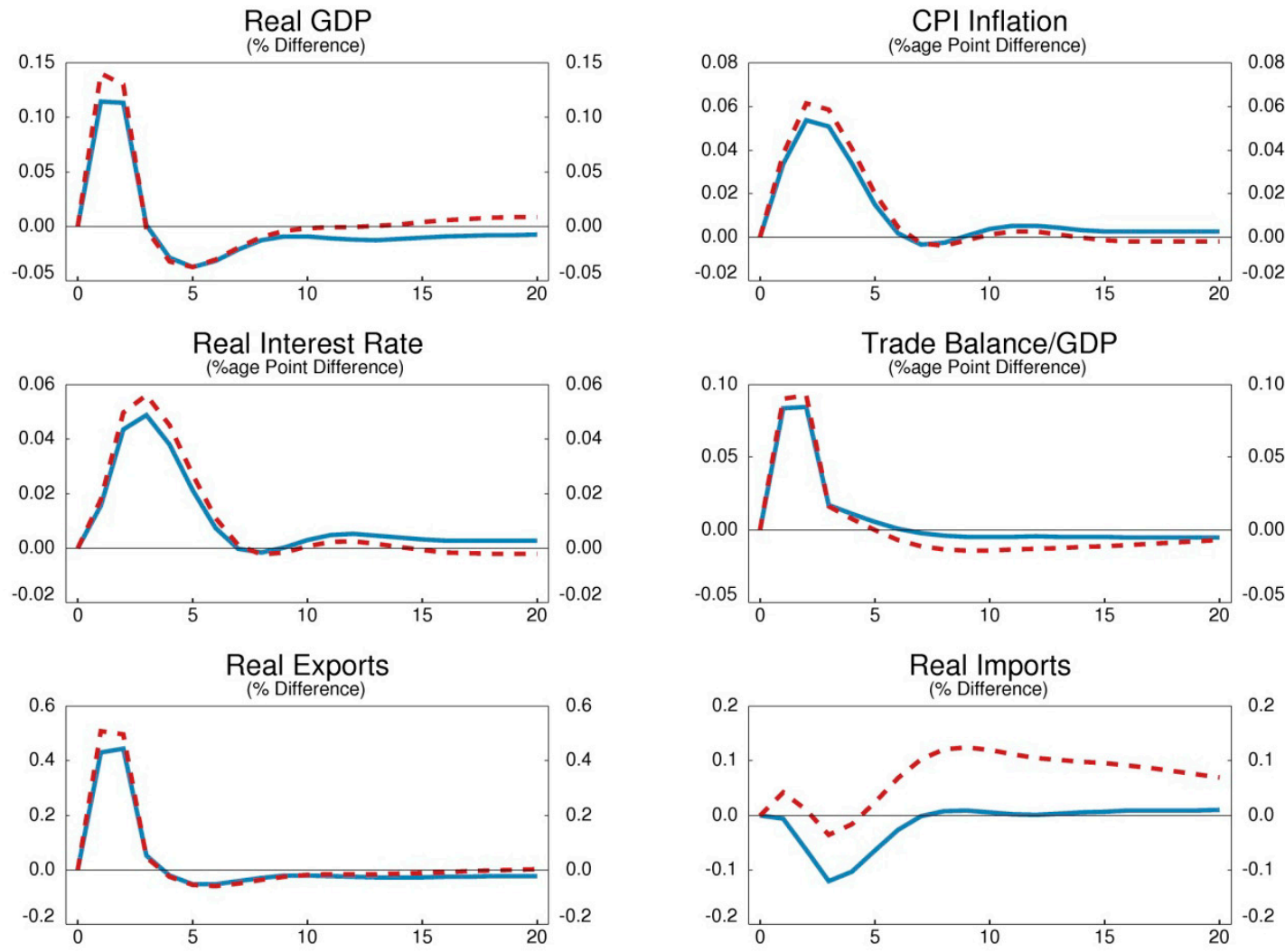


\section{Two Year Increase in Lumpsum Transfers - General versus Targeted to LIQ Households}

Figure 3 shows the effects of the U.S. government increasing both lumpsum transfers to all households and lumpsum transfers to only LIQ households by 1 percentage point of baseline GDP for two years. Transfers do not feed into aggregate demand directly, but indirectly through household incomes. The increase in general transfers is split between households with access to capital markets (OLG households) and those without (LIQ households), based on their share of the total population (75\% and $25 \%$ in the United States, respectively). Real GDP and inflation rise only marginally when general lumpsum transfers are increased. When targeted lumpsum transfers are increased, real GDP increases by just under $1 / 2$ percent, while inflation rises by less than $1 / 4$ percentage point.

When temporarily higher transfers are directed only to LIQ households, there is a large immediate increase in private consumption and aggregate demand, since LIQ households spend all of their current income. The increase in aggregate demand puts additional pressure on the costs of production, and leads to rising inflation. In response, the U.S. monetary authority raises the nominal interest rate, which flows through to real interest rates. Higher real interest rates increase the cost of capital, dampening private investment. Higher interest rates also offset the impact of higher household incomes on consumption expenditure. In addition, the automatic fiscal stabilizers operate such that transfers adjust to dampen private demand as well. These factors lead to a fiscal multiplier below unity.

The increase in real interest rates appreciates the U.S. real effective exchange rate, lowering import prices for U.S. residents and raising the cost of U.S. exports abroad. Lower import prices increase U.S. demand for imports from abroad, while higher export prices decrease foreign demand for U.S. goods. The net impact is a temporary deterioration in the current account.

When the temporary increase in transfers is split between each type of household, the effects are qualitatively similar, but much smaller, since OLG households will smooth their consumption because of their access to capital markets. Thus the boost to private consumption, and aggregate demand, is primarily driven by the transfers to the LIQ households, whose income increases much less than under the case of targeted transfers. 
Figure 3:

Temporary Stimulus Through Increased Lumpsum Transfers (1\% of GDP For 2 Years) Effects in United States

Percent or percentage point difference from steady-state baseline

(Horizontal axis is in years: $L R=$ Long Run)
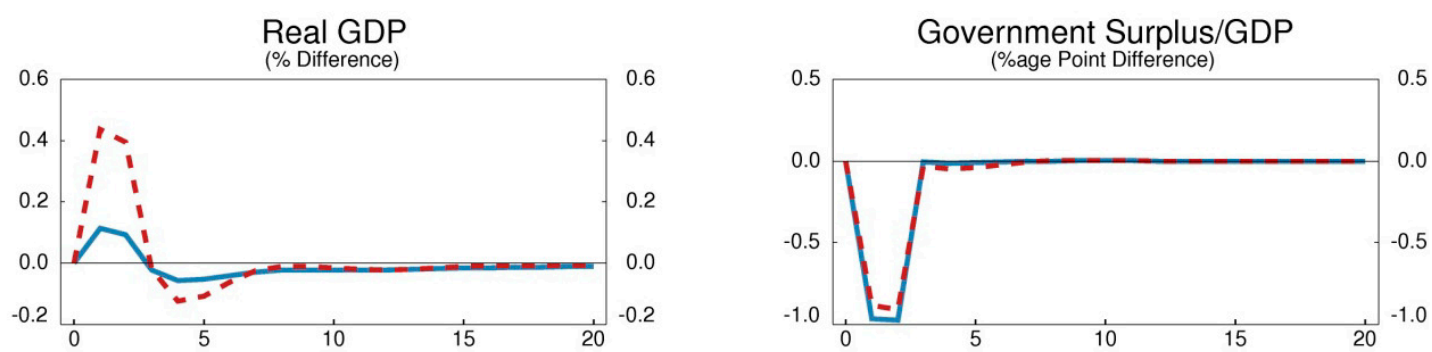

Real Private Consumption

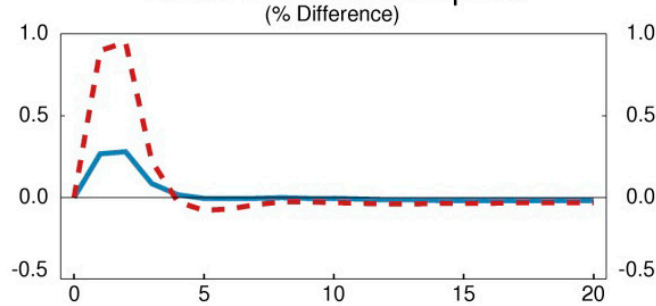

Liquidity Constrained Consumption

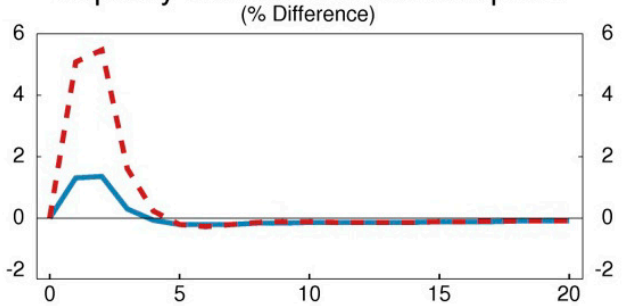

Total Transfers/GDP

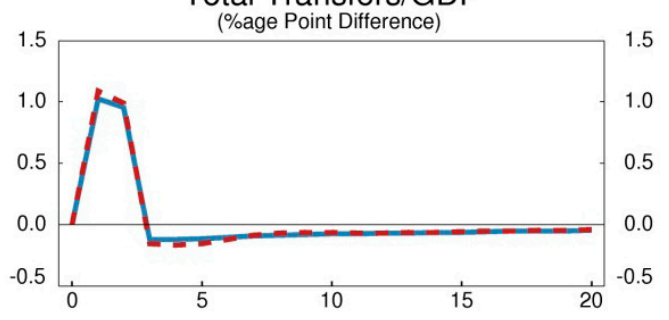

Gov't Debt/GDP

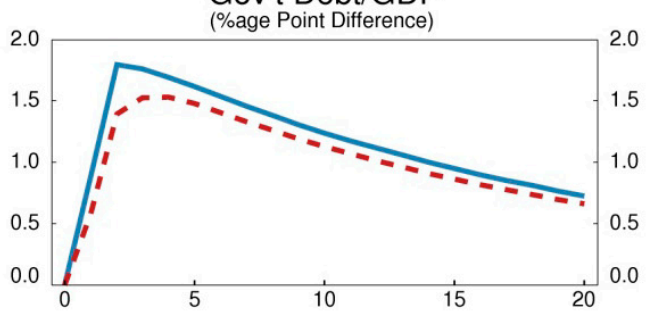

CPI Inflation

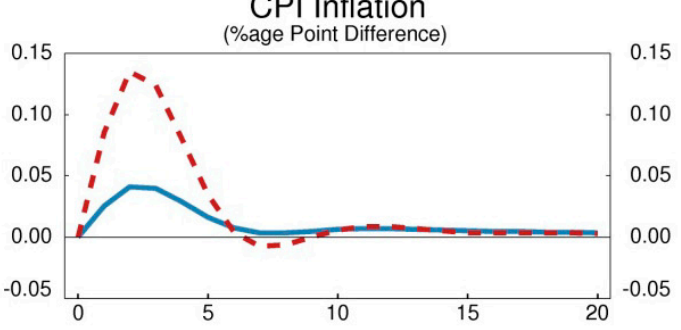

Real Interest Rate

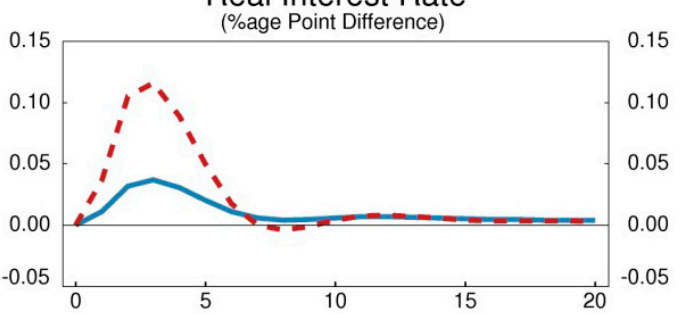

Real Effective Exchange Rate
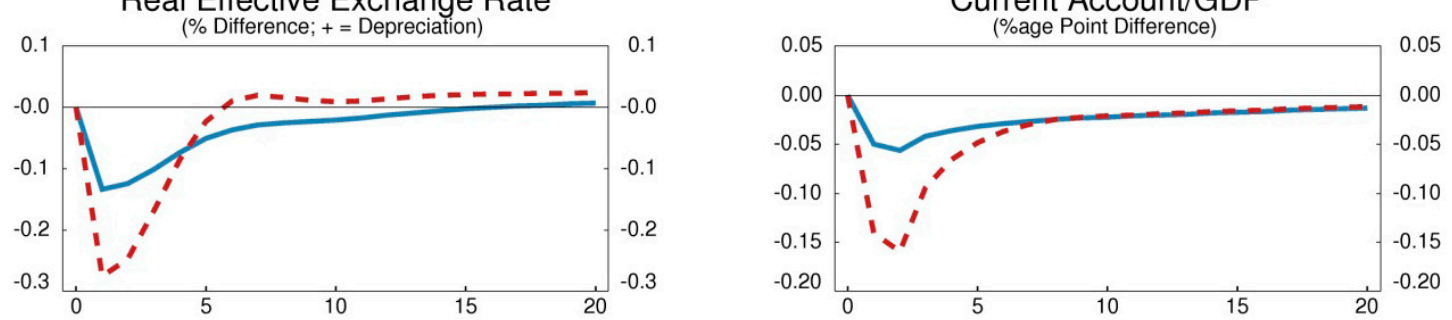


\section{Two Year Decrease in Taxation}

Figure 4 compares the effects of the U.S. government decreasing taxation by 1 percent of baseline GDP for 2 years using each of the three different taxes: consumption taxes, labor income taxes, or corporate income taxes. All of these tax cuts produce modest GDP growth of roughly $1 / 4$ percent. Inflation rises only marginally under reductions in capital and consumption taxes, and is essentially unchanged under the reduction in labor taxes.

Each of these changes in the tax rates propagate through the economy differently. Consumption and labor income taxes primarily affect households. Since the tax cuts are temporary, their effects are transmitted more by LIQ households, as the OLG households, who smooth their consumption, respond little to short-lived shocks that have only a small impact on their life-time income. The corporate income tax cut primarily affects firms.

Consumption taxes directly decrease the price households pay for consumption goods, leading to higher private consumption for two years. This increases the demand for labor, raising wages and the marginal cost of production. This results in mild increase in the pre-tax price of domestically produced goods, leading to a slight pickup in CPI inflation (the CPI excludes indirect taxes).

Lower labor income taxes raise the quantity of labor supplied by households. Higher household incomes, derived from lower tax rates and increased labor effort, lead households to raise consumption expenditure. The increase in aggregate demand offsets the downward pressure on wages from increased labor supply, leaving the marginal cost of production and inflation roughly unchanged.

When the government lowers corporate income tax rates, the return on capital rises, which increases household income. Higher returns induce firms to invest more, and private consumption expenditure also accelerates. Stronger private demand prompts firms to demand more labor, which increases the marginal cost of production, and thus the price for domestically produced goods. The resulting acceleration in inflation leads to the U.S. monetary authority slightly raising the nominal policy rate. The resulting higher real interest rate increases the cost of capital, dampening private investment, and also offsets the impact of higher household incomes on consumption expenditure.

In all three cases, the increase in the real interest rate leads to an appreciation of the U.S. real effective exchange rate, lowering import prices for U.S. residents and raising the cost of U.S. exports abroad. Lower import prices increase U.S. demand for imports from abroad, while higher export prices decrease foreign demand for U.S. goods. In addition, the automatic fiscal stabilizers also operate, with transfers declining to dampen private demand. Together these factors lead to fiscal multipliers well below unity. 
Figure 4:

Temporary Stimulus Through Lower Taxation (1\% of GDP for 2 Years) Effects in United States

Percent or percentage point deviation from steady-state baseline (Horizontal axis is in years: LR = Long Run)
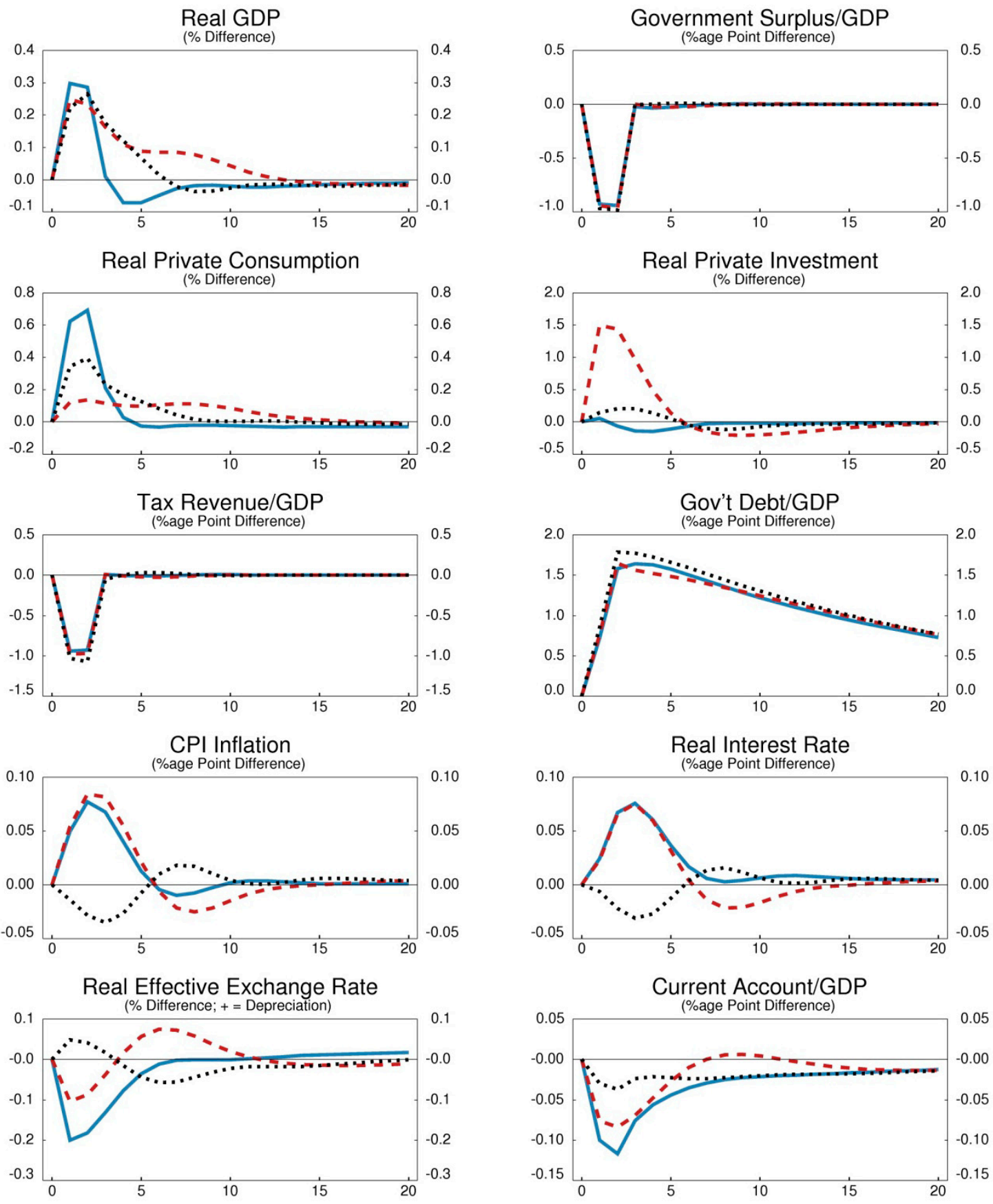


\section{Box I:}

\section{The Impact on Fiscal Multipliers of Monetary Accommodation}

During periods of fiscal stimulus when there is significant slack in the economy, the monetary authority may not need to respond, as the stimulus would be unlikely to drive inflation above its target rate. The results presented in the table below illustrate the magnifying effects of monetary accommodation on the fiscal multipliers associated with a range of different fiscal instruments. In this case, the fiscal multiplier is defined as the average deviation of real GDP from baseline during the two years of fiscal stimulus. As in the rest of this section, the fiscal stimulus measures are a 1 percent of GDP increase in the government surplus, achieved by changing one of the seven fiscal instruments.

Because such accommodation leads to real interest rates notably below those that prevail if monetary policy responds, the impact of the fiscal stimulus on real activity is larger. Moreover, the longer the period of monetary accommodation, the greater the increase in the multiplier, as households expect inflation to respond more, thereby reducing the real interest rate even further. For example, one year of monetary accommodation when the fiscal stimulus is through government consumption results in an additional $1 / 4$ percent of real GDP on average during the two years, while moving to two years of monetary accommodation leads to an additional $1 / 2$ percent of real GDP on average.

Table 1:

Fiscal Multipliers with Monetary Accommodation, Average GDP Impact after First Two Years (Percent Deviation from Baseline)

\begin{tabular}{|c|c|c|c|}
\hline Instrument & $\begin{array}{c}\text { No } \\
\text { Accommodation }\end{array}$ & $\begin{array}{c}\text { One Year of } \\
\text { Accommodation }\end{array}$ & $\begin{array}{c}\text { Two Years of } \\
\text { Accommodation }\end{array}$ \\
\hline Gov't. Consumption & 0.76 & 0.92 & 1.43 \\
\hline Gov't. Investment & 1.17 & 1.36 & 1.89 \\
\hline General Transfers & 0.10 & 0.13 & 0.24 \\
\hline Transfers to LIQ Households & 0.42 & 0.52 & 0.86 \\
\hline Consumption Tax & 0.29 & 0.35 & 0.56 \\
\hline Corporate Income Tax & 0.24 & 0.31 & 0.52 \\
\hline
\end{tabular}




\section{B. Permanent Fiscal Consolidation}

This subsection presents the effects of fiscal consolidation based on a permanent reduction in government debt by adjusting one of the seven fiscal instruments. All of the reported results are in terms of deviation from the steady-state baseline.

\section{Permanent Fiscal Consolidation through Government Spending - Consumption versus Investment}

Figure 5 shows the effects of the U.S. government achieving a permanent 20 percentage point reduction in the ratio of public debt to GDP by initially reducing public expenditures by one percent of baseline GDP. In the case of government consumption spending, real GDP initially declines by almost 1 percent before recovering and stabilizing slightly above baseline in the long run. Inflation falls by almost $1 / 4$ percentage point before returning to baseline levels after five years. Consolidating via government investment causes real GDP to decrease by a similar 1 percent in the first period, but thereafter real GDP declines for an extended period before stabilizing slightly above baseline in the long run. Inflation falls by almost $1 / 2$ percentage point before returning close to baseline levels after 10 years.

When the government initially lowers its consumption spending, aggregate demand takes an immediate hit. With output demand falling, firms reduce demand for both capital and labor, and real wages fall. Weaker demand also leads to declining inflation, prompting the U.S. monetary authority to respond by cutting the nominal policy interest rate, which flows through to real interest rates, lowering the cost of capital and inducing households to save less. This easing in monetary policy eventually returns inflation to target. The permanently lower level of public debt implies less demand for global savings, and the global real interest rate declines to equilibrate demand and supply for savings. The lower global real interest rate crowds in private investment, resulting in real GDP above the initial baseline level in the long run. Also, the lower interest payments on government debt allow the government to start gradually reversing the reduction in consumption spending. In the long run, public consumption spending is able to rise above its previous baseline level. The lower interest rate also leads to a shift away from private saving. Households increase the consumption of both goods and leisure, and labor supply declines.

In the case where the decrease in the government debt is achieved by a cut in government investment expenditures, there is a profound negative impact on real GDP that lasts for an extended period. The fall in government investment leads to a lower public capital stock, which is equivalent to a large negative productivity shock in the economy, undermining capacity. This leads to a decrease in the demand for the factors of production, reducing households' incomes and their ability to consume, as well as the level of investment needed to maintain the desired private capital stock. This effect on real GDP recedes in the long run, 
and real GDP rises above baseline exactly as in the case where government consumption expenditures are initially reduced.

In both cases, the U.S. real effective exchange rate depreciates in the short run in response to the fall in real interest rates. This raises import prices for U.S. residents and lowers the price of U.S. produced goods abroad, which increases foreign demand for U.S. exports and decreases domestic demand for imports from abroad. With increased U.S. saving, the U.S. net foreign liabilities position and current account balance improve in the new steady state and the real effective exchange rate appreciates in the long run.

Figure 6 shows the effects of a permanent decrease in U.S. government spending in the rest of the world. In the short run, the downward pressure on inflation from cheaper U.S. goods and the deteriorating trade balance prompt the foreign monetary authorities to cut their nominal policy interest rates. Additionally, with the U.S. public debt-to-GDP ratio lower in the new steady state, the world real interest rate falls in the long run. Both the short- and long-run declines in interest rates stimulate private investment in foreign economies. Foreign current accounts fall with the trade balance, although the effects may differ on a region-byregion basis, depending on the nature of their trade linkages with the United States, and each other. In the long run, real GDP increases owing to the lower world real interest rates. 
Figure 5:

Permanent Consolidation Through Decreased Government Spending ( $1 \%$ of GDP) Effects in United States

Percent or percentage point deviation from steady-state baseline

(Horizontal axis is in years: $L R=$ Long Run)

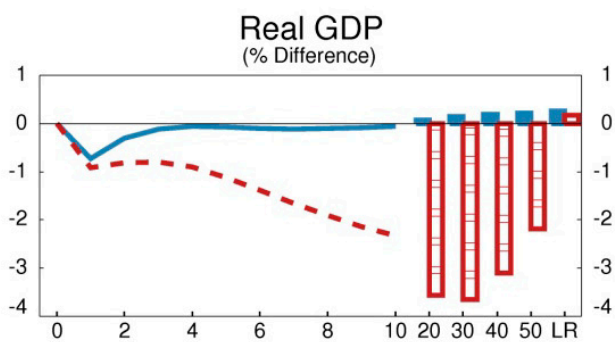

Real Private Consumption

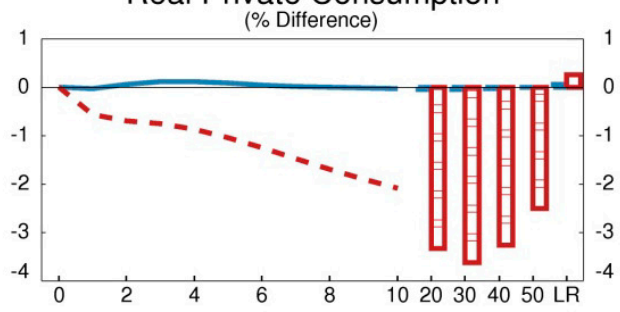

Interest Payments/GDP

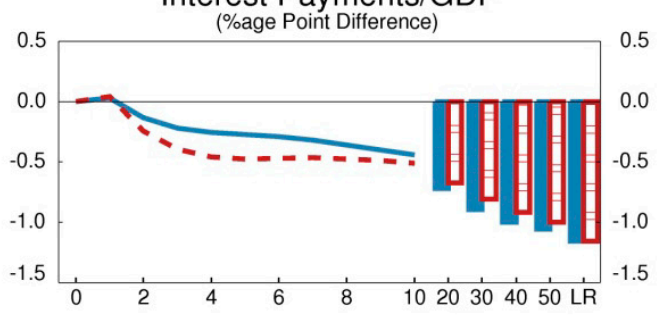

CPI Inflation

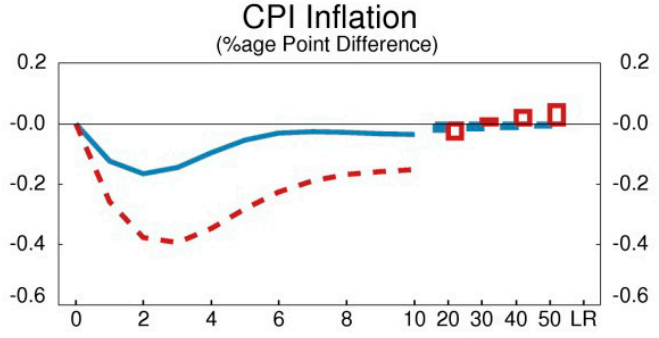

Real Effective Exchange Rate

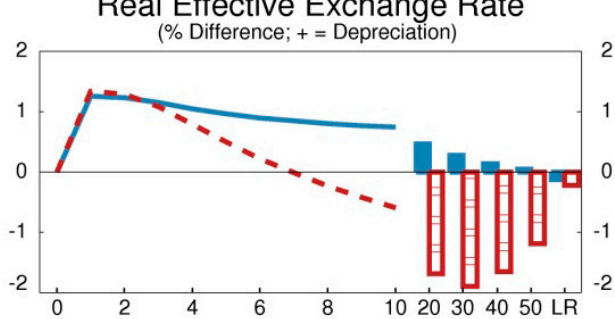

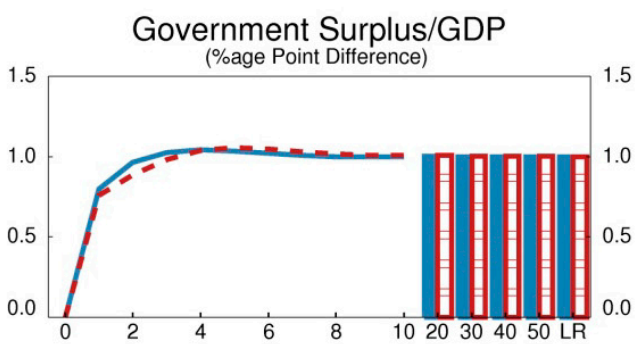

Real Private Investment

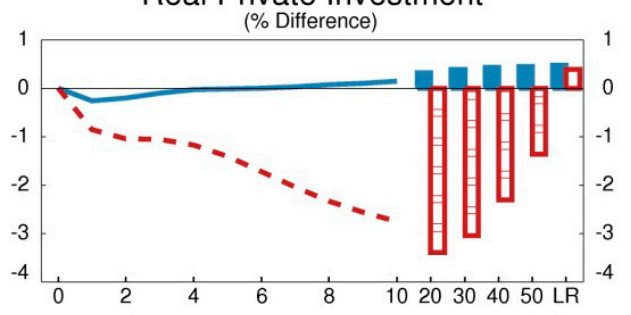

Government Spending/GDP

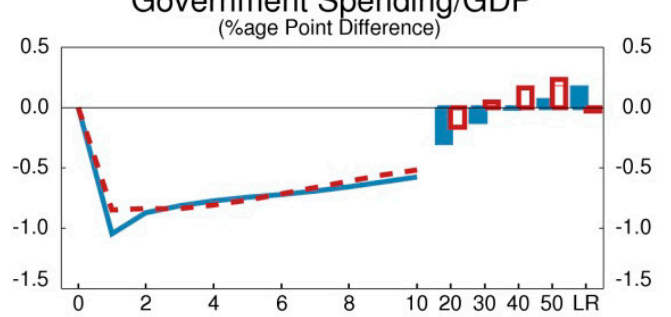

Real Interest Rate

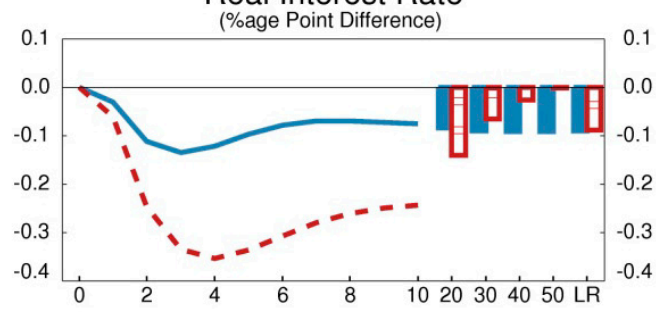

Current Account/GDP

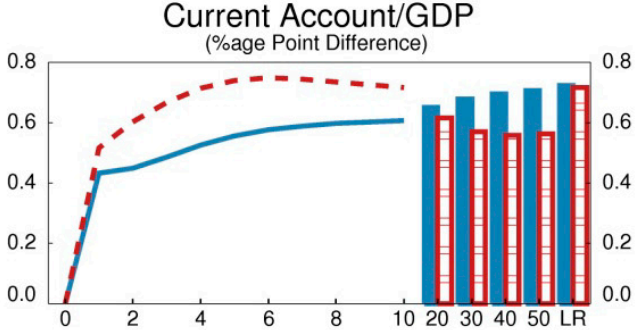


Figure 6:

Permanent Consolidation Through Decreased Government Spending (1\% of GDP) Effects in the Rest of the World

Percent or percentage point deviation from steady-state baseline (Horizontal axis is in years: $L R=$ Long Run)
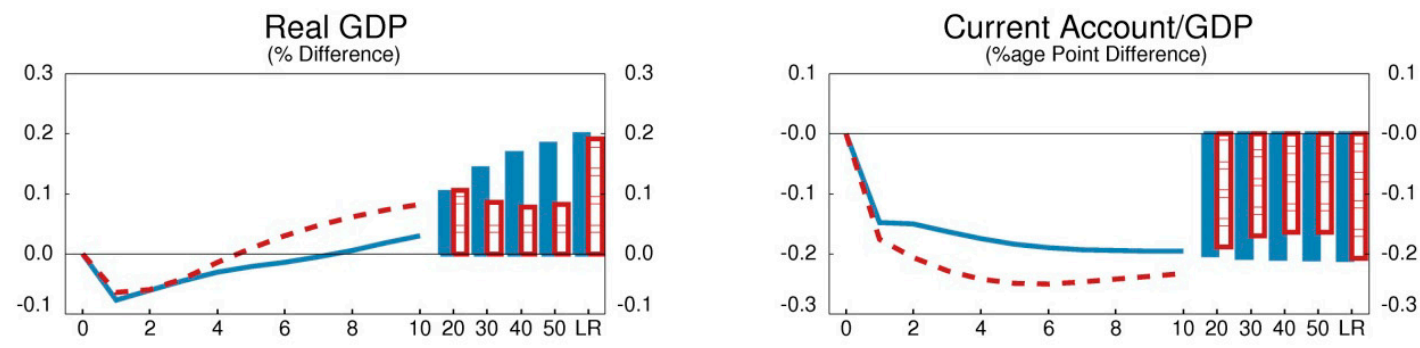

Trade Balance/GDP

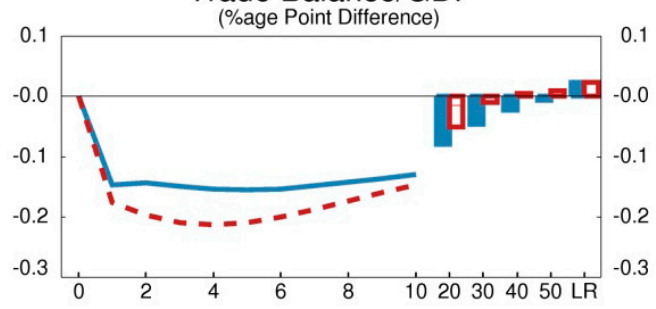

Real Interest Rate

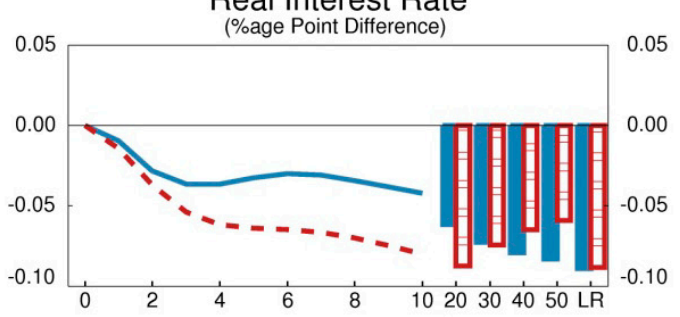

CPI Inflation
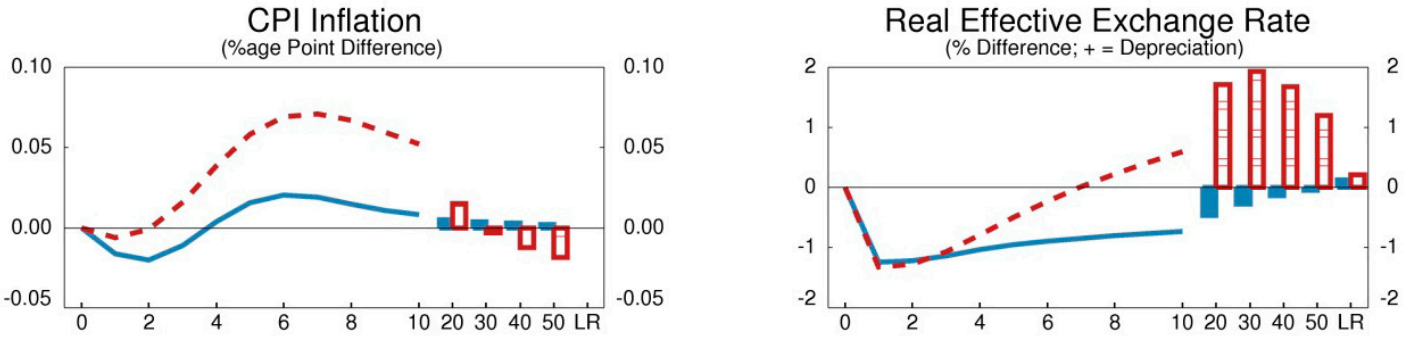

\section{Permanent Fiscal Consolidation through Lumpsum Transfers - General versus Targeted to LIQ Households}

Figure 7 shows the effects of the U.S. government achieving a permanent 20 percentage point reduction in the debt-to-GDP ratio by initially reducing public lumpsum transfers, either to all households (general transfers), or to only LIQ households (targeted transfers), by 1 percent of baseline GDP. As a result, real GDP falls marginally in the first year, but subsequently begins to rise. In the long run, real GDP increases by under $1 / 4$ percent in both cases. Inflation also falls slightly before returning to baseline levels under cuts in both types of transfers.

When the government reduces the transfers targeted to only LIQ households, their consumption expenditure falls immediately by the full amount of the decline in their transfers. This decrease in aggregate demand reduces pressure on the costs of production, and leads to disinflation. The U.S. monetary authority decreases nominal interest rates, which flows through to real rates, lowering the cost of capital and causing an increase in private 
investment. Lower interest rates also act to offset the effect of lower household income, decreasing private saving and stimulating private consumption. The permanently lower level of public debt implies less demand for global savings, and the global real interest rate declines to equilibrate demand and supply for savings. The lower global real interest rate crowds in private investment, resulting in real GDP above the initial baseline level in the long run. The lower level of public debt and reduction in global interest rates lead to lower interest payments. Consequently, the government can gradually undo its cuts in transfers to households. In the long run, transfers as a share of GDP are roughly $1 / 4$ percentage point higher than in the baseline.

The U.S. real effective exchange rate depreciates in response to the fall in real interest rates. This raises import prices for U.S. residents and lowers U.S. export prices abroad, which increases foreign demand for U.S. exports and decreases domestic demand for imports from abroad. With increased U.S. saving, the U.S. net foreign asset position and current account balance are improved in the new steady state, and the real effective exchange rate appreciates.

When transfers are cut to both OLG and LIQ households, the initial negative impact on activity is muted. First of all, LIQ households experience a smaller decrease in their income, as $75 \%$ of the cut in transfers falls on OLG households, based on their population share. The decline in aggregate GDP is less pronounced, as OLG households are able to smooth consumption by using their savings. All households are less wealthy in the near term, so just as in the case of only targeted transfers, they increase their supply of labor, lowering the real wage. This lowers the marginal cost of domestic production, which in turn causes prices of domestic goods to fall. The monetary policy channel and the effects on the external sector are qualitatively the same, but muted relative to the case where only LIQ agents' transfers are initially cut.

The global effects of this consolidation by the U.S. government are shown in figure 8 . In the short run, the downward pressure on inflation from cheaper U.S. goods and the deteriorating trade balance prompt the foreign monetary authorities to cut their nominal policy interest rates. Additionally, with the U.S. public debt-to-GDP ratio lower in the new steady state, world real interest rates fall in the long run. Both the short- and long-run declines in interest rates stimulate private investment in foreign economies. Foreign current accounts fall with the trade balance, although the effects may differ on a region-by-region basis, depending on the nature of their trade linkages with the United States, and each other. In the long run, real GDP increases due to lower world real interest rates. 
Figure 7:

Permanent Consolidation Through Decreased Lumpsum Transfers (1\% of GDP) Effects in United States

Percent or percentage point deviation from steady-state baseline

(Horizontal axis is in years: LR = Long Run)
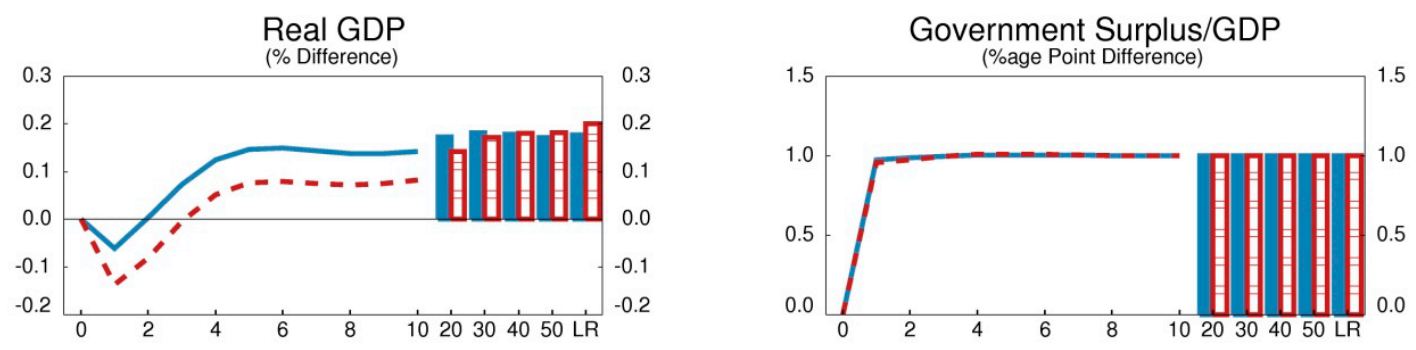

Real Private Consumption

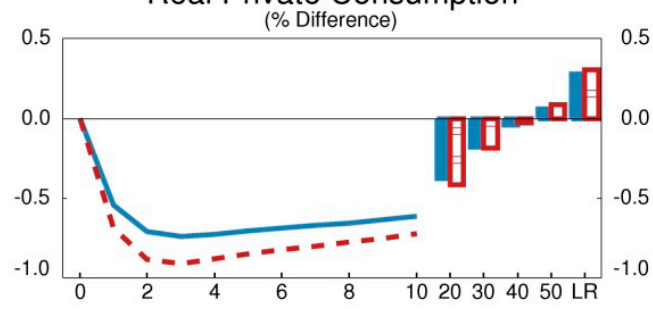

Liquidity Constrained Consumption

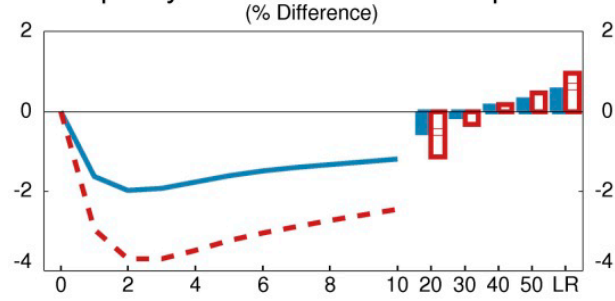

Interest Payments/GDP

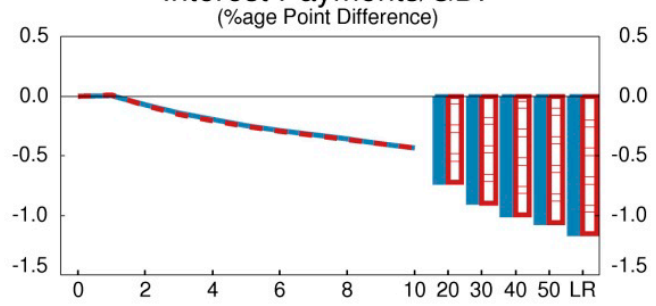

Total Transfers/GDP

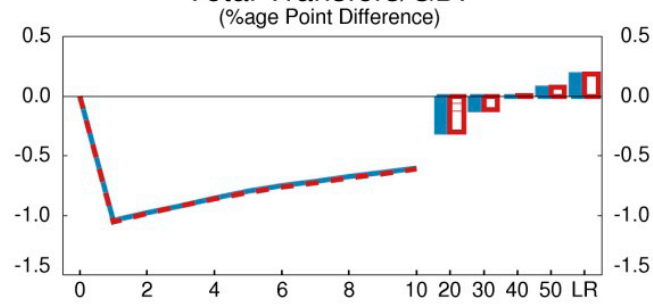

CPI Inflation

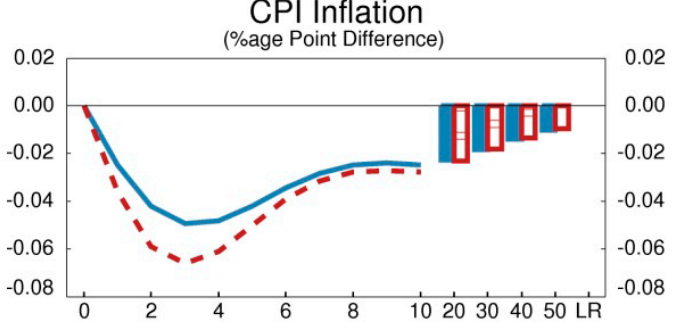

Real Interest Rate

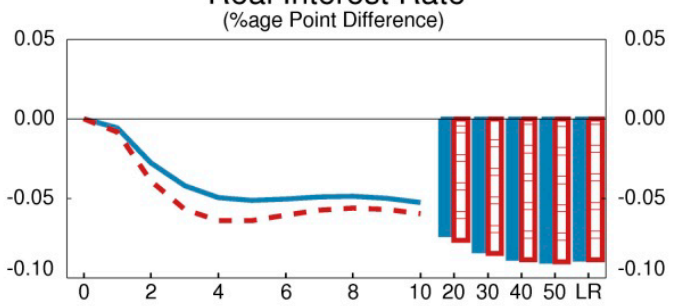

Real Effective Exchange Rate
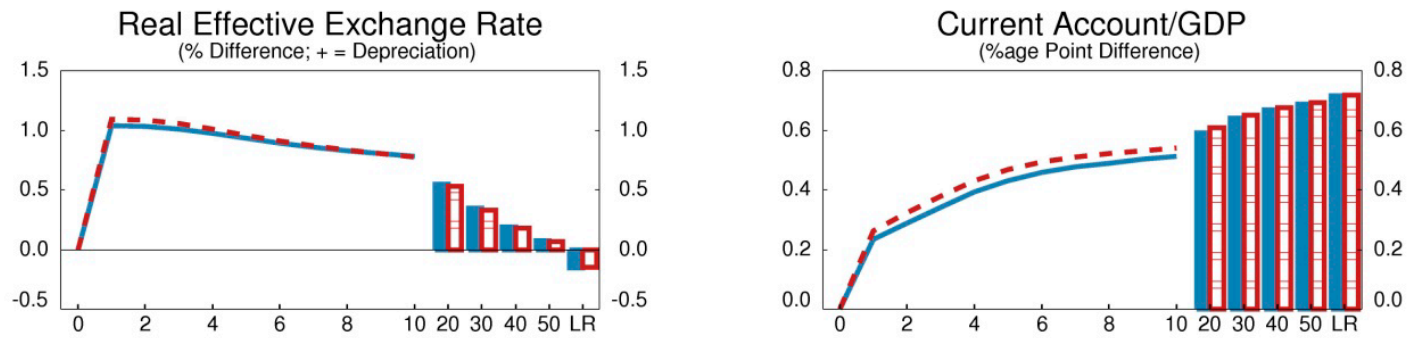
Figure 8:

Permanent Consolidation Through Decreased Lumpsum Transfers ( $1 \%$ of GDP) Effects in the Rest of the World

Percent or percentage point deviation from steady-state baseline (Horizontal axis is in years: $L R=$ Long Run)
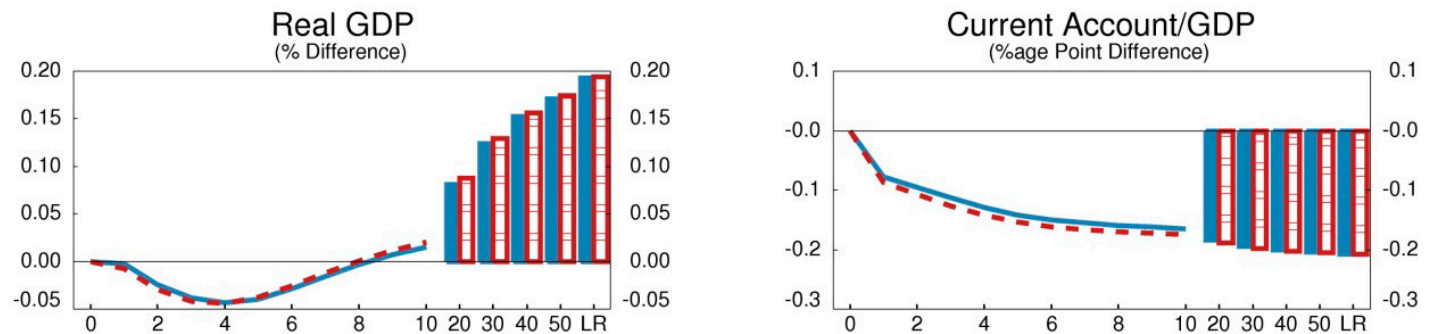

Trade Balance/GDP

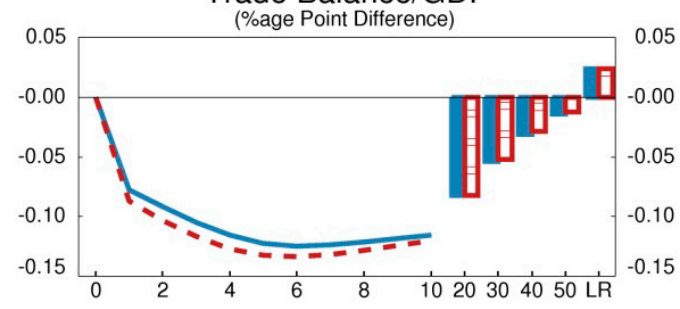

Real Interest Rate

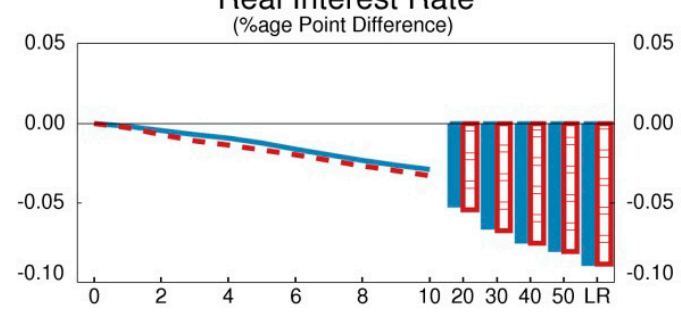

CPI Inflation

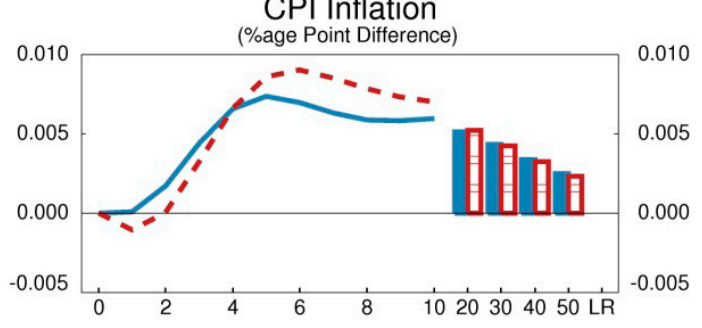

Real Effective Exchange Rate

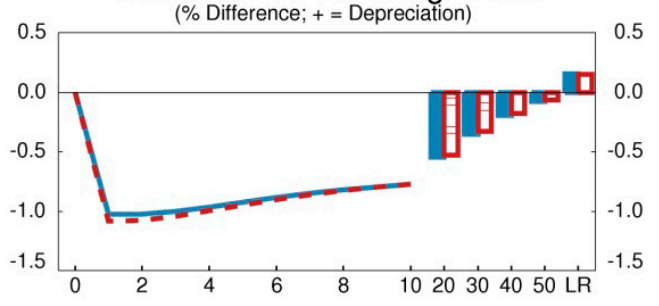




\section{Permanent Fiscal Consolidation through Increased Taxation}

Figure 9 compares the effects of the U.S. government achieving a permanent 20 percentage point reduction in the ratio of public debt to GDP by initially increasing taxation by 1 percent of baseline GDP using one of the three different tax rates; consumption taxes, labor income taxes, or corporate income taxes.

Each of these changes in a tax rate propagates through the economy differently, but the longrun effects are mostly from the same mechanism, lower global real interest rates and taxes. Regardless of the tax rate being used, the permanent reduction in the U.S. debt-to-GDP ratio implies an increase in global savings, which leads to a fall in global real interest rates of roughly 10 basis points in the long run. Lower interest rates and less government debt result in a reduction in debt-service costs. This means that the government can eventually more than reverse the initial increase in the relevant tax rate.

In the short run, real GDP drops the most when corporate income taxes are raised, over $1 / 2$ percent, followed by labor income taxes at roughly $1 / 2$ percent, and then consumption taxes at around $1 / 4$ percent. In the long run, real GDP will be above baseline, as the fiscal authority can unwind the initial tax increase, plus provide a small tax cut. The cut in corporate income taxes will have the greatest positive effect on real GDP, followed by labor income taxes, and then consumption taxes. Inflation also falls as all three tax rates are initially increased, but the decline is notably larger for the corporate income tax rate cut, as it has the largest negative impact on demand in the near term. In response, the U.S. monetary authority cuts the nominal policy interest rate, which flows through to real interest rates in the short run, even before the long-run fall in the debt level permanently ensures lower real and nominal interest rates.

There are other individual effects worth noting as well. Consumption and labor income tax hikes primarily affect households, whereas an increase in the corporate income tax rate primarily affects firms. When the government increases the consumption tax, the level of consumption immediately declines, as well as private saving. Households work less as they decide to consume more leisure, given the return to labor effort has declined. The negative impact of the increase in the consumption tax more than offsets any increased incentives coming from firms increasing the real wage to induce more labor supply. Therefore, aggregate demand falls in the short to medium run. In the case of a hike in the labor income tax rate, households also choose to work less and consume more leisure, but labor supply falls by more than in the case of higher consumption taxes. Consequently, the output decline is larger than under the consumption tax increase, because firms' labor cost rises by more, leading to a greater decline in investment. When the government increases the corporate income tax rate, there is a larger drop in investment given the sharp decline in the return to capital. The decline in investment is long-lived because firms' desired level of capital falls 
for an extended period of time, depressing productive capacity. Therefore, real GDP is lower, even with the larger offset from lower real interest rates in the short to medium run.

The U.S. real effective exchange rate depreciates in response to the fall in real interest rates. This raises import prices for U.S. residents and lowers U.S. export prices abroad, which increases foreign demand for U.S. exports and decreases domestic demand for imports from abroad. The U.S. net foreign asset position and current account balance improve in the new steady state and the real effective exchange rate appreciates.

Figure 10 shows the effects of fiscal consolidation in the United States on the rest of the world. In the short run, the downward pressure on inflation from cheaper U.S. goods and the deteriorating trade balance prompt the foreign monetary authorities to cut their nominal policy interest rates. Additionally, with the U.S. public debt-to-GDP ratio lower in the new steady state, world real interest rates fall. Both of these interest rate effects stimulate private investment in foreign economies. Foreign current accounts fall with the trade balance, although the effects may differ on a region-by-region basis, depending on the nature of their trade linkages with the United States, and each other. In the long run, real GDP increases owing to lower world real interest rates. 
Figure 9:

Permanent Consolidation Through Higher Taxation ( $1 \%$ of GDP) Effects in United States

Percent or percentage point deviation from steady-state baseline (Horizontal axis is in years: $L R=$ Long Run)

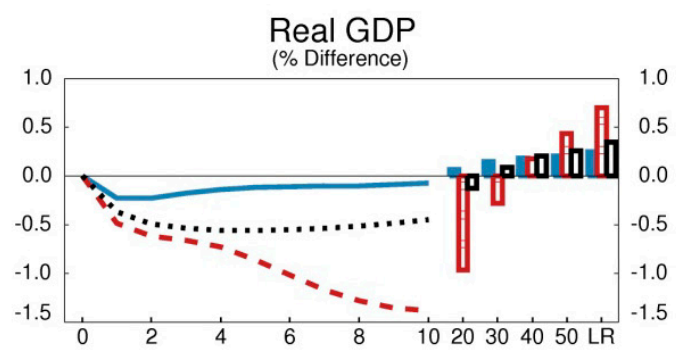

Real Private Consumption

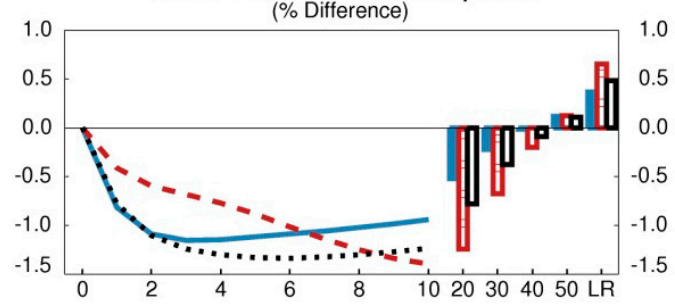

Interest Payments/GDP

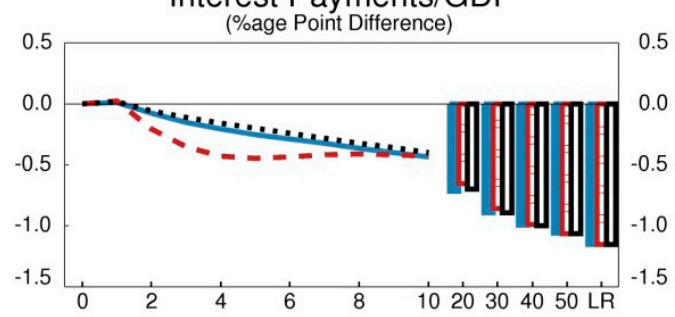

CPI Inflation

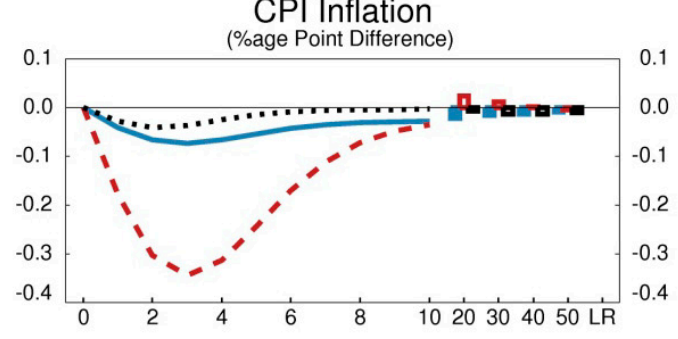

Real Effective Exchange Rate

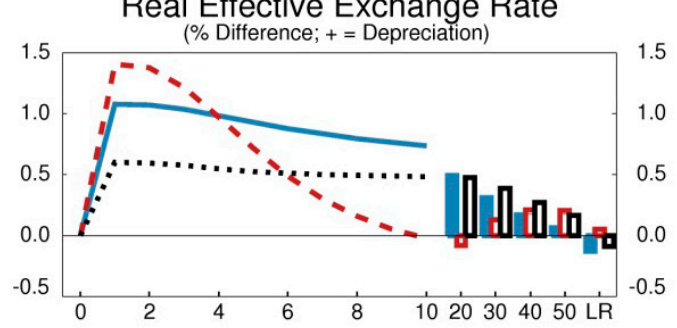

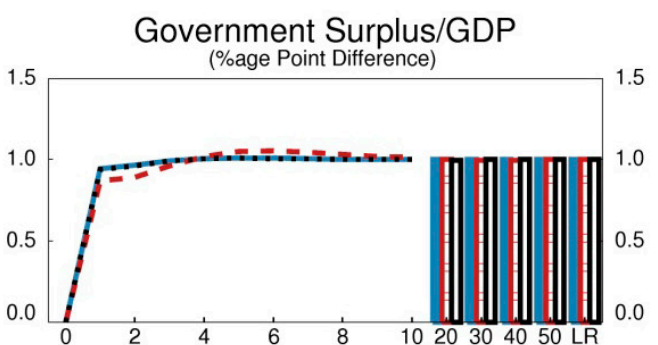

Real Private Investment

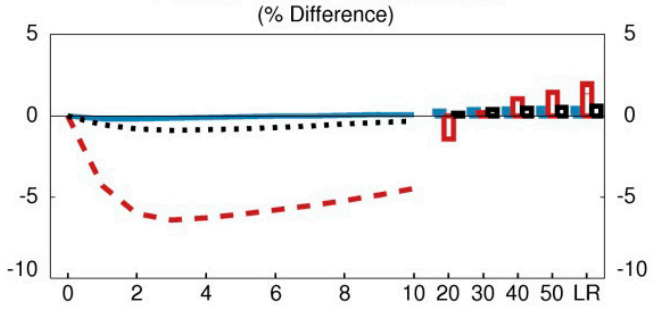

Total Tax Revenue/GDP
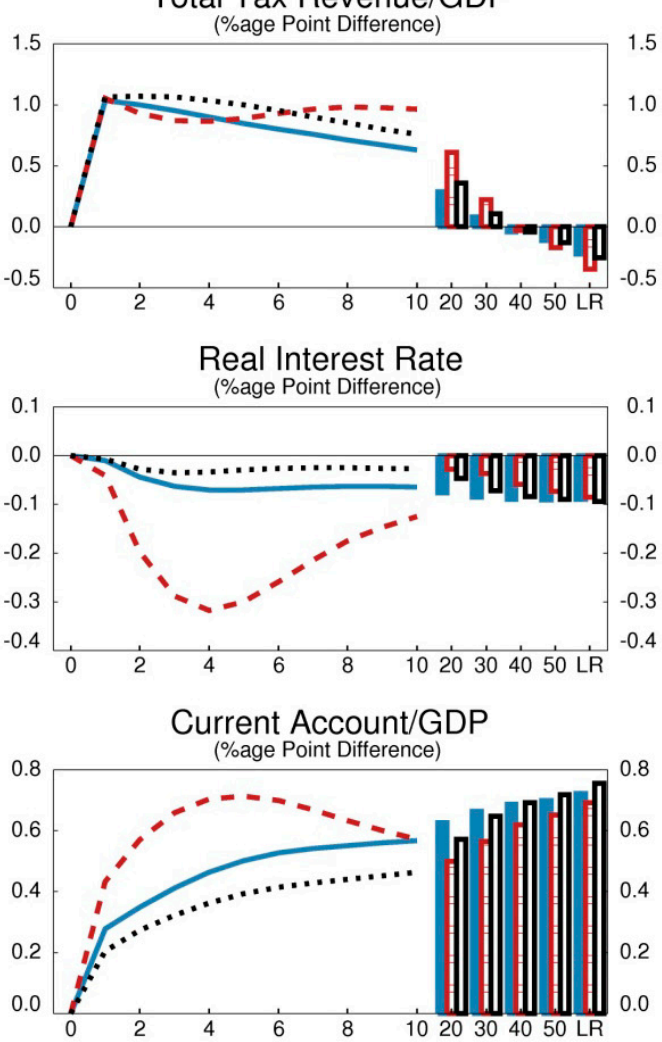
Figure 10:

Permanent Consolidation Through Higher Taxation ( $1 \%$ of GDP) Effects in the Rest of the World

Percent or percentage point deviation from steady-state baseline (Horizontal axis is in years: $L R=$ Long Run)
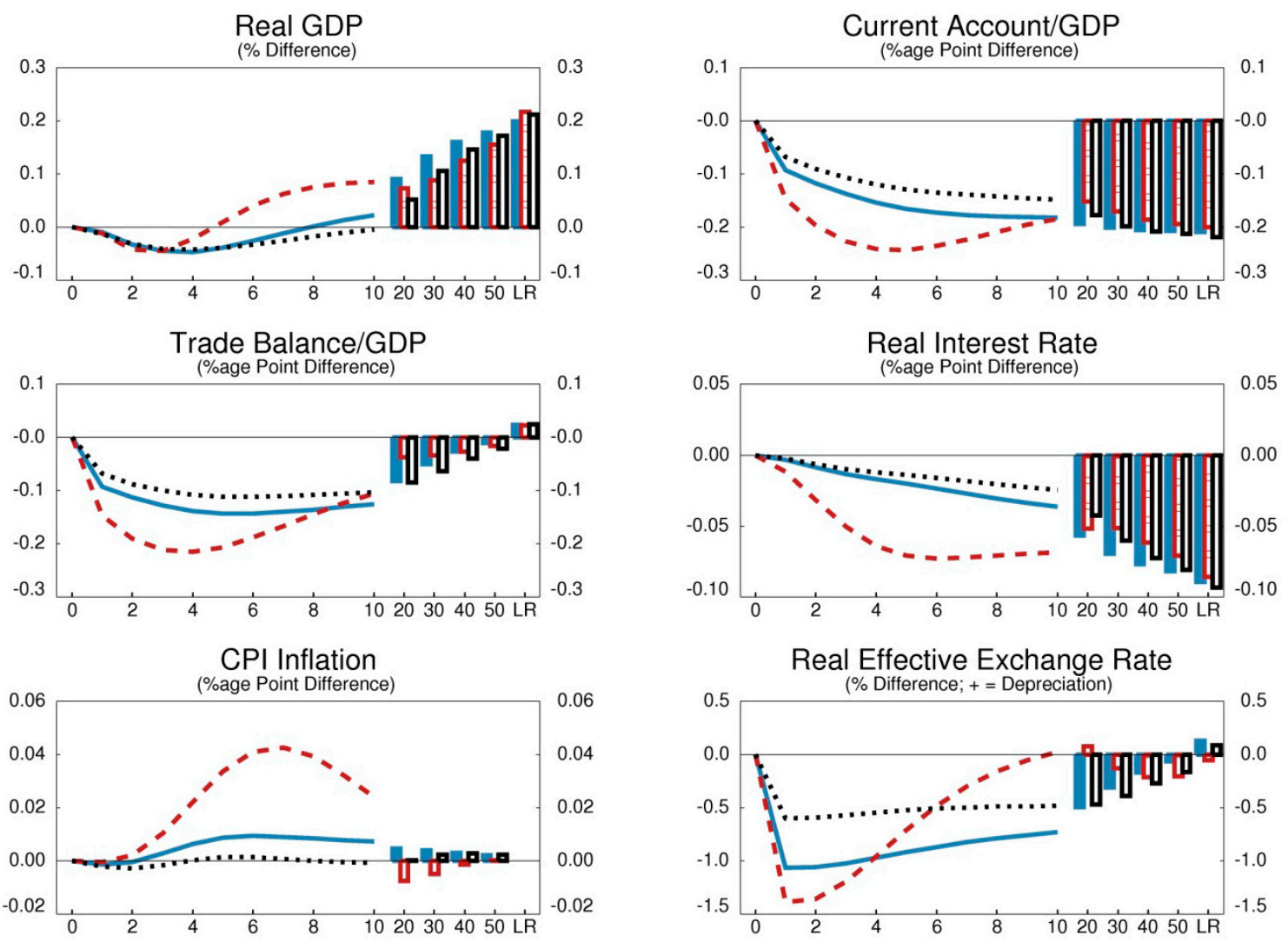

\section{Permanent Fiscal Consolidation and the Issue of Credibility}

When considering fiscal policy, and fiscal consolidation in particular, there is the additional concern of the credibility of an announced policy. When examining properties in most models, since they are simulated under an environment of certainty, it is difficult to illustrate the implications of policy announcements that only become credible gradually over time as policy makers follow through on their announced actions. However, we can employ techniques that proxy the implications of households gradually coming to the realization that the fiscal authority is actually going to implement announced policies.

In this section, we consider fiscal consolidation in the United States, using a reduction in government consumption in order to generate a permanent improvement in the government surplus by 1 percentage point of GDP, as in the first part of Section III.B. Therefore, the government debt is 20 percentage points lower in the long run. However, the short run 
dynamics can be notably different, depending on how credible the fiscal consolidation is perceived to be in its early years.

When analyzing the fiscal consolidation, we consider three different ways in which households and firms perceive the announced consolidation. First, agents immediately believe that all announced future policy will be implemented. Second, it takes one year before agents believe that the government will follow through with announced future policies. Third, it takes two years before agents believe announced future policies will be implemented. When agents do not perceive a fiscal consolidation to be credible, they assume that the announced change in the fiscal stance will only last one year, followed by a permanent return to the previous fiscal stance.

Recall our first the case where households believe the announced consolidation to be fully credible (Figure 5). Real GDP falls immediately, in line with the decrease in government spending, and the government surplus rises. This puts downward pressure on inflation rates, leading to lower interest rates, both nominal and real. Therefore, private consumption and investment begin to strengthen after falling in the first year. In the long run, the fiscal consolidation increases the supply of aggregate saving in the United States, and the world, leading to a permanent fall in the equilibrium world real interest rate. Private saving decreases, although not enough to offset the increase in public saving, while private investment increases, raising the productive capacity of the economy. The lower world real interest rate means households shift permanently into consumption from private saving, as they now discount lifetime income at a lower rate, and consider themselves to be wealthier today. Consequently, U.S. real GDP increases by $1 / 2$ percent, relative to the baseline. The lower world real interest rate is also the main source of global spillovers, as real GDP is permanently higher everywhere. There is a general re-equilibration of current accounts globally, which accounts for the global increase in investment, balanced by the global decrease in private saving, and the increase in U.S. government saving.

Figure 11 demonstrates that the short-run impact of the fiscal consolidation scenario looks very different depending on when the future fiscal consolidation becomes fully believed. In the periods when households do not believe future consolidation will occur, they do not anticipate a permanent fall in the interest rate, so they do not begin shifting into consumption from private saving; the only increase in consumption comes from the easing in monetary policy. Similarly, firms, which are owned by the households, do not increase their investment, other than in response to the shift in monetary policy. Therefore, real GDP falls further than under full credibility. The fall in real GDP in the United States is more severe the longer it takes for households to believe that the future fiscal consolidation will in fact occur.

The implications of households not fully believing the commitments to future fiscal plans can also interact with the zero nominal interest rate floor (ZIF). Since a typical monetary policy response to a fiscal contraction would be to lower policy interest rates to stimulate activity, it 
is worthwhile illustrating the impact of nominal interest rates being constrained at zero when households do not initially believe announced future consolidation plans. Fiscal consolidation will have a direct negative impact on the economy through lower aggregate demand. However, if the ZIF is binding, there is an additional negative channel. With nominal interest rates unable to decline, weaker aggregate demand will reduce inflation and real interest rates will rise, further dampening aggregate demand.

Table 2 presents the scenario that uses a reduction in government consumption to achieve the desired fiscal consolidation. If the ZIF is binding, the positive effects from monetary policy easing will be absent, resulting in a further decline in real GDP. Again, the longer the ZIF is binding, the further real GDP will fall. Also, with one exception, the ZIF effect is magnified under consolidations when households do not fully believe the government's commitment to the announced fiscal plan. In the first year of the consolidation with the ZIF binding for two years, the GDP effect is largest when then is no uncertainty about the government's commitment to the future consolidation path. So why is the real GDP loss larger when the future fiscal consolidation is fully believed in the first year? If households believe the government will follow through on the consolidation plan, they understand that the weakness in activity will be prolonged relative to the case where they expect the spending cut to last only one year. If the ZIF is also binding in the second year, then inflation is also expected to be notably lower in the second year and thus the current real interest rate even higher. This further depresses aggregate demand in the first year.

Table 2:

Government Consumption Multipliers with Varying Assumptions Real GDP in the United States

(Percent Deviation from Baseline)

Year 1 Year 2 Year 3 Year 4 Year 5 Long Run

\section{Credible Immediately}

$\begin{array}{ccccccc}\text { No ZIF } & -0.71 & -0.35 & -0.16 & -0.06 & -0.05 & 0.23 \\ \text { 1-Year ZIF } & -0.87 & -0.56 & -0.16 & -0.01 & -0.01 & 0.23 \\ \text { 2-Year ZIF } & -1.57 & -1.28 & -0.62 & 0.19 & 0.24 & 0.23\end{array}$

Credible in Year 2

No ZIF

$-0.88 \quad-0.63$

$-0.25$

$\begin{array}{ll}-0.09 & -0.03\end{array}$

0.23

1-Year ZIF

$-1.03$

$-0.82$

$-0.25$

$-0.04$

0.00

0.23

2-Year ZIF

$-1.56$

$-1.53$

$-0.80$

0.11

0.24

0.23

Credible in Year 3

No ZIF

$-0.88$

$-0.81$

$-0.54$

$-0.19$

$-0.06$

0.23

1-Year ZIF

$-1.03-1.28$

$-0.46$

$-0.07$

0.03

0.23

2-Year ZIF

$-1.56$

$-2.01$

$-1.03$

$0.08 \quad 0.28$

0.23 
Figure 11:

Fiscal Consolidation Scenario Based on a Decrease in Government Consumption Effects in United States

Percent or percentage point deviation from steady-state baseline (Horizontal axis is in years)
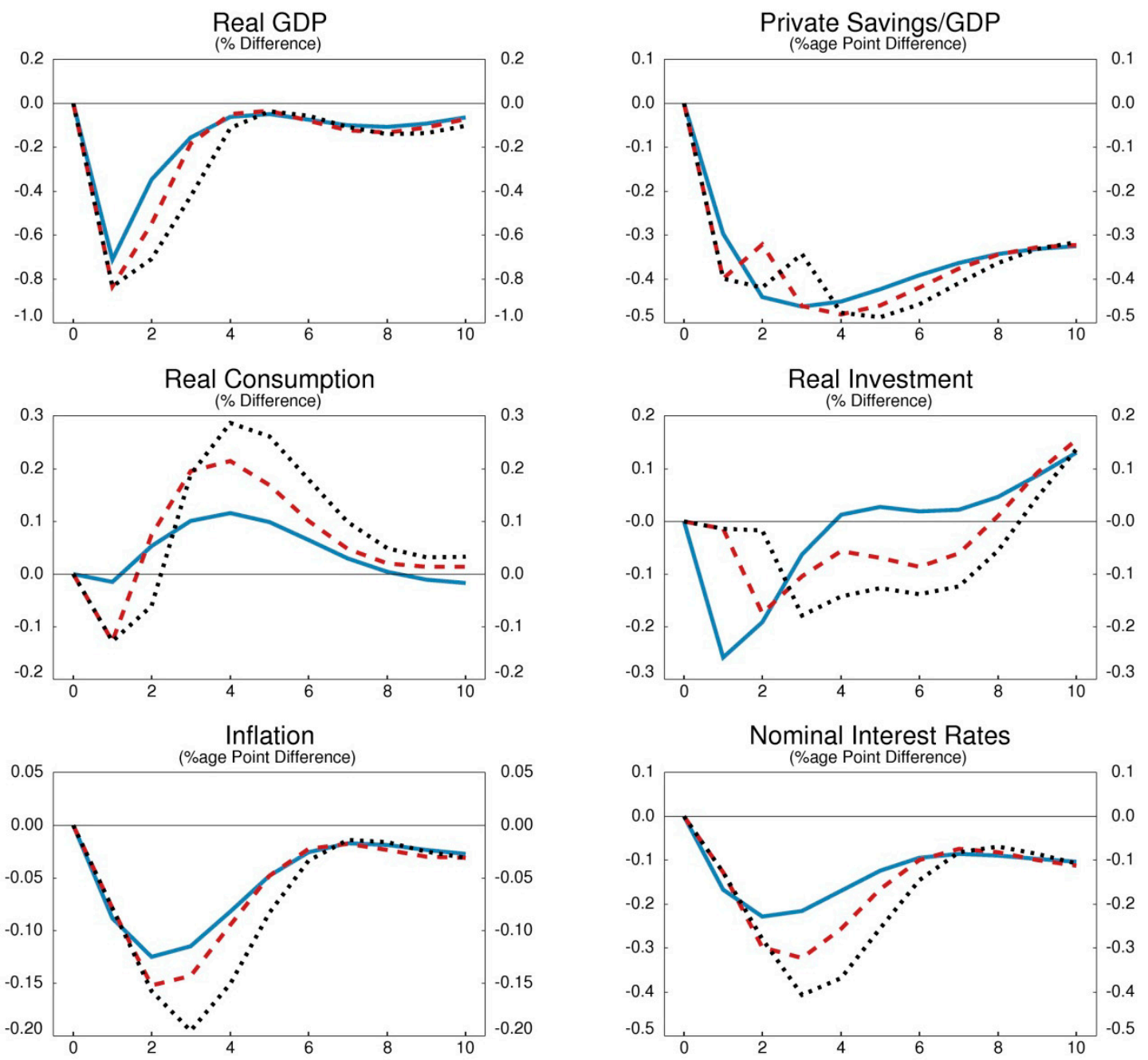

\section{Properties of Financial ANd Monetary Shocks}

This section presents the effects of shocks to monetary policy and the financial sector in the United States, and the spillovers to the rest of the world where applicable. The impact of monetary policy is demonstrated through a temporary increase in the monetary policy rate. Financial sector properties are highlighted by an increase in borrower riskiness. Furthermore, there are two additional boxes that explore the role of the Bernanke-Gertler-Gilchrist financial accelerator (Boxes II and III). 


\section{A. Temporary Increase in the Nominal Interest Rate}

Figure 12 shows the effects of a one-year, 100 basis point increase in the U.S. nominal policy interest rate. On impact, U.S. GDP decreases by almost $3 / 4$ percent, reflecting falls in both domestic demand and exports. Inflation decreases by almost $1 / 2$ percentage point at its trough in the second year.

In the U.S. economy, higher real interest rates reduce both private investment and household consumption expenditures. Business investment declines due to the higher user cost of capital. This in turn diminishes the profitability of firms, lowering the stream of future dividends and thereby reducing household wealth. The contraction in production decreases the demand for labor, resulting in lower employment and wages. The fall in labor income and wealth leads households to decrease consumption expenditures.

The response of the real effective exchange rate helps to further dampen demand for U.S. output. Higher real interest rates appreciate the U.S. dollar, reducing import prices for U.S. residents, and raising the price of U.S. exports in the rest of the world. Cheaper imports lead to some expenditure switching away from domestic toward foreign goods in the United States. Additionally, foreign demand declines for the now more expensive U.S. exports. The net impact of all these factors is a slight deterioration in the U.S. current account in the short run.

The fall in demand for U.S. output implies firms need to employ fewer factors of production, and labor demand declines. The decrease in labor demand leads to lower real wages, reducing marginal costs and output prices. Consequently, price inflation for domestically produced goods declines. Lower import prices, owing to the appreciation of the U.S. dollar, impart additional downward pressure on inflation.

Since fiscal policy strives to stabilize activity, the deficit increases as automatic stabilizers work in the short run. Further, increased debt-service costs, arising from higher interest rates, add to the deficit. Eventually, the fiscal authority reduces general transfers to households to return the public debt-to-GDP ratio back to its long-run target. Following the exogenously induced tightening, monetary policy must also ease to return inflation to target. The monetary authority reduces the nominal interest rate to achieve a period with real interest rates below their neutral level, temporarily stimulating aggregate demand and re-anchoring inflation at the target.

Figure 13 shows the effects of this temporary increase in U.S. monetary policy rate on the rest of the world. The spillovers in this experiment are transmitted mainly through trade linkages and are relatively small. Thus, for the remainder of the experiments covered in this section, results for the rest of the world will not be presented. 
Figure 12:

One Year 1 Percentage Point Increase in the Nominal Interest Rate Effects in United States

Percent or percentage point deviation from steady-state baseline (Horizontal axis is in years: $L R=$ Long Run)
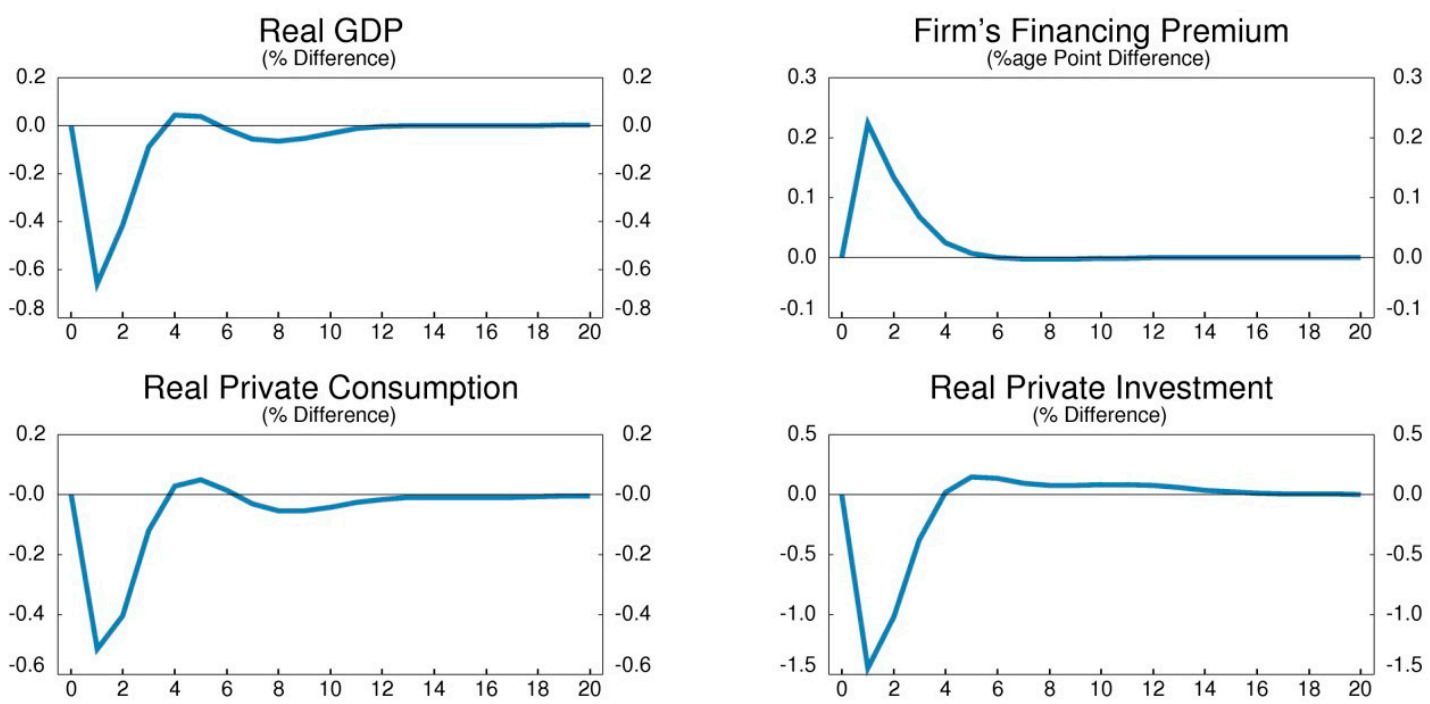

Real Exports
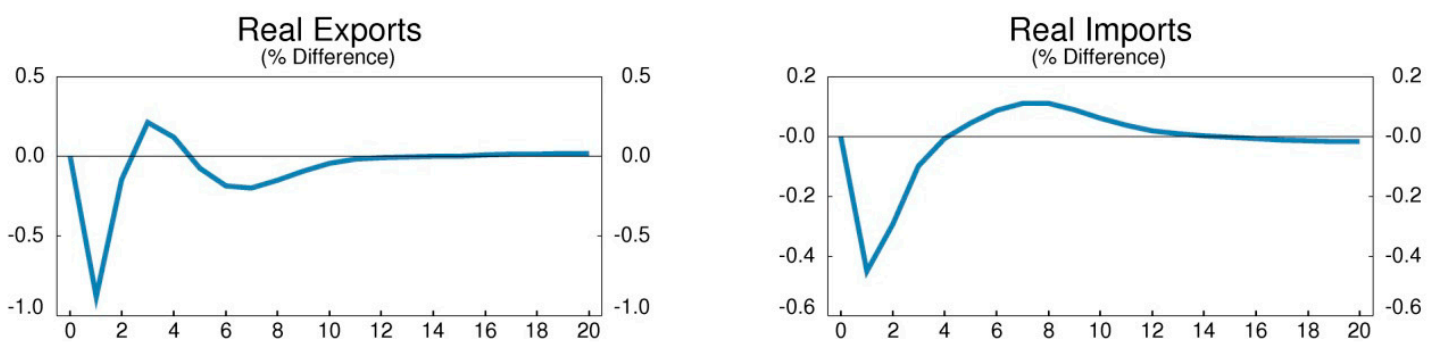

CPI Inflation

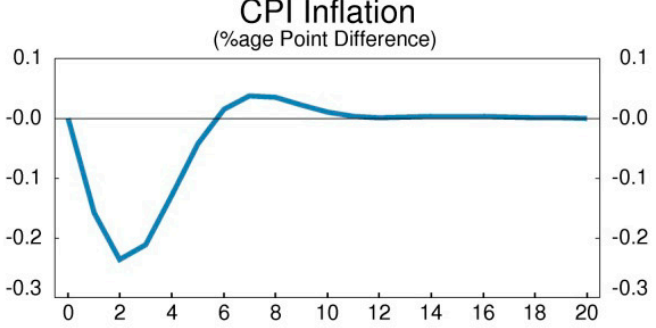

Nominal Interest Rate _ _ Real Interest Rate - -

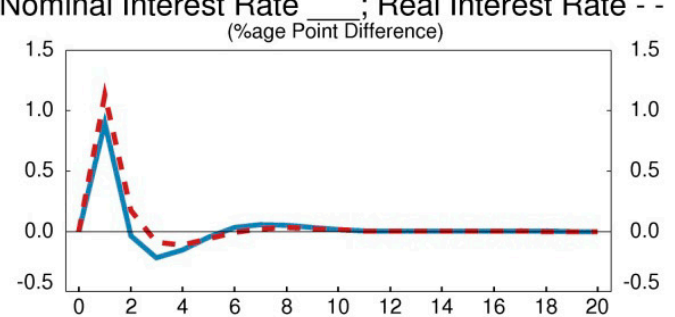

Trade Balance _, Current Account - -
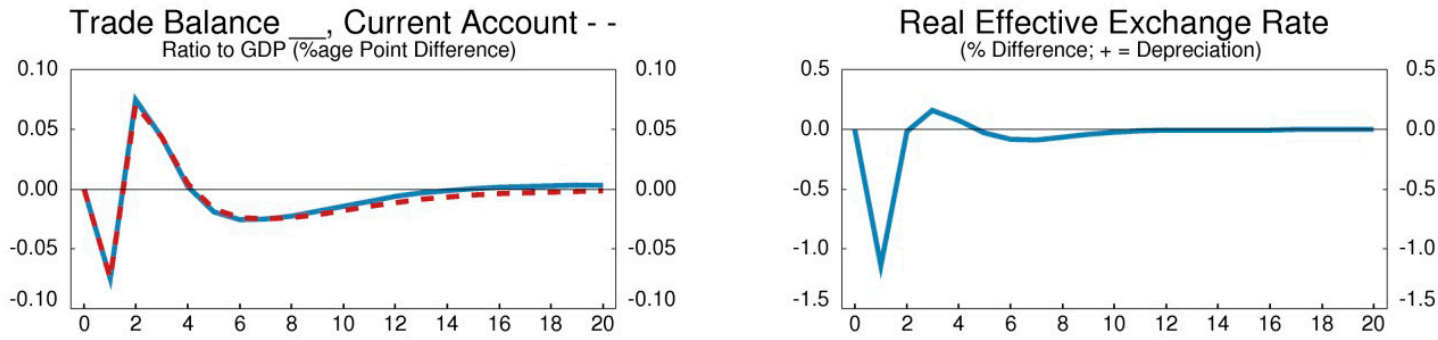
Figure 13:

One Year 1 Percentage Point Increase in the Nominal Interest Rate Effects in the Rest of the World

Percent or percentage point deviation from steady-state baseline

(Horizontal axis is in years: $L R=$ Long Run)
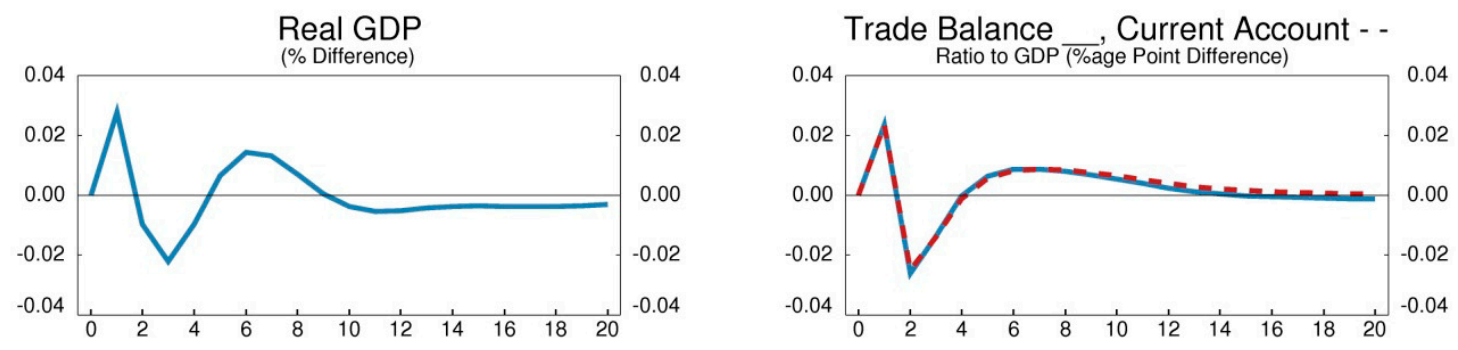

Nominal Interest Rate $\quad$; CPI Inflation - -
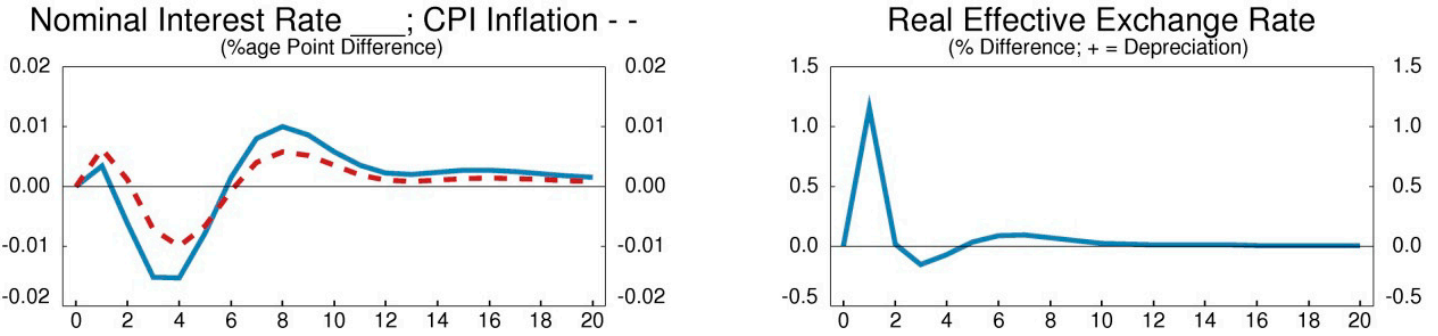


\section{B. Temporary but Persistent Increase in Borrowers' Riskiness}

Figure 14 shows the effects of a temporary but persistent increase in the riskiness of U.S. corporate borrowers that raises the corporate financing premium by 1 percentage point on impact. The shift in risk perception is persistent, but it declines by roughly half every 2 years. Real GDP declines by approximately $1 / 2$ percent on impact because of the fall in domestic demand, particularly investment, while inflation falls by less than $1 / 4$ percentage point.

The perceived increase in corporate riskiness raises the borrowing cost faced by firms. Thus, there is an immediate increase in the cost of capital and therefore business investment declines. A higher cost of capital also reduces profitability, leading to lower dividends and a fall in household wealth. Higher costs also lead firms to decrease production and demand less labor, driving down wages. Lower employment and wage rates reduce household labor income, and consumption expenditure declines, but by much less than investment spending.

Weaker economic activity reduces inflation slightly. In response to lower inflation, the monetary authority decreases the policy interest rate in an effort to stimulate demand and return inflation to target. As a result, there is a slight fall in the short-term real interest rate, which yields a small real depreciation of the currency. Consequently, U.S. exports increase slightly, while imports fall (also in response to the fall in domestic demand). Overall, the current account improves modestly in the short run.

The change in corporate riskiness has a minor impact on fiscal policy variables through the operation of automatic stabilizers. However, the fiscal deficit returns to balance quickly. 
Figure 14:

Temporary but Persistent Increase in Borrower Riskiness Effects in United States

Percent or percentage point deviation from steady-state baseline (Horizontal axis is in years)

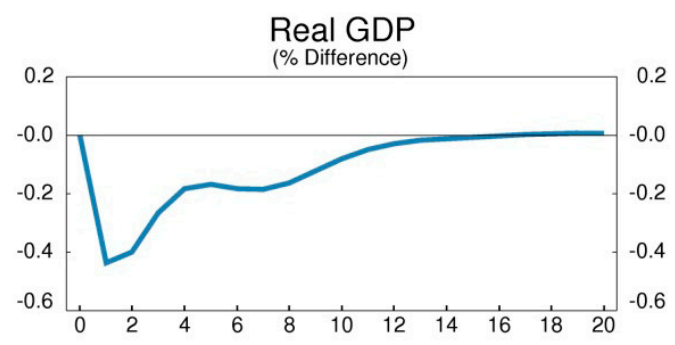

Real Private Consumption

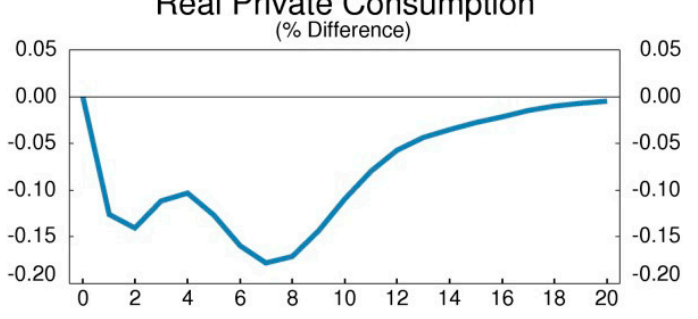

Real Exports

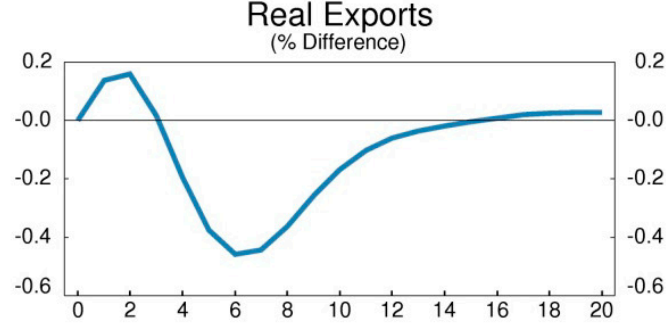

CPI Inflation

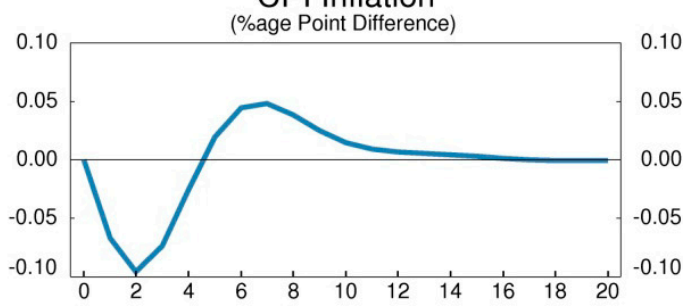

Trade Balance _, Current Account - -

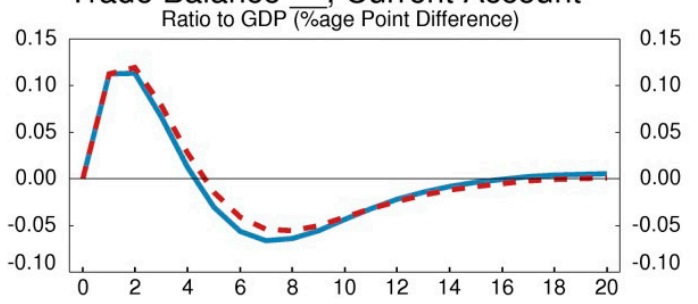

Firm's Financing Premium

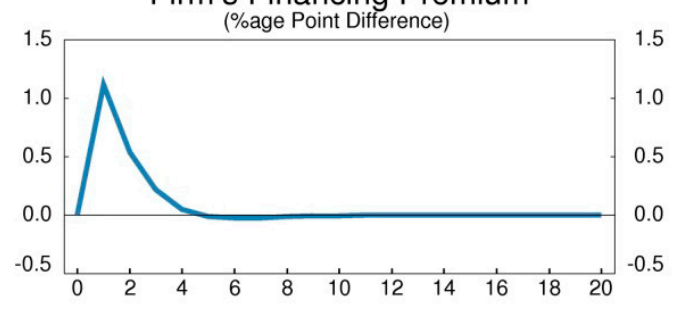

Real Private Investment
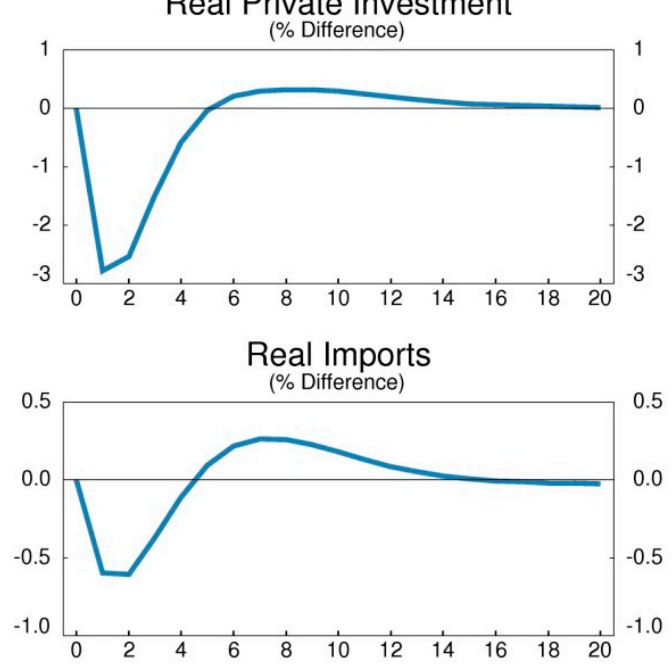

Nominal Interest Rate _ ; Real Interest Rate ...

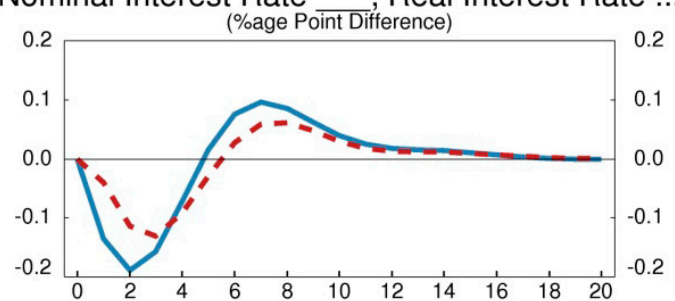

Real Effective Exchange Rate

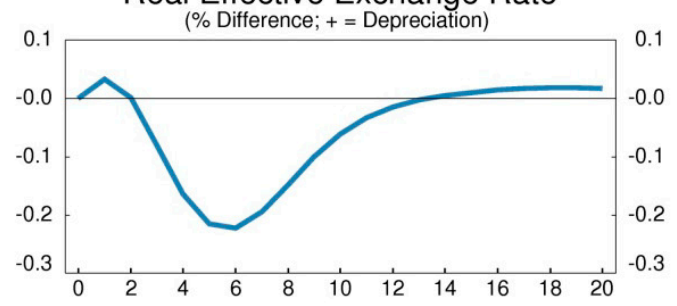




\section{Box II: \\ Impact of the BGG Financial Accelerator}

GIMF incorporates the financial accelerator adapted from Bernanke, Gertler, and Gilchrist (1999). In Figure 15, the impact of the accelerator can be seen in both the increase in consumption resulting from a temporary decline in savings, and a temporary 10-year increase in the productivity growth rate. Consider first the temporary increase in consumption through a temporary shift in the pure rate of the time preference, the left hand column in Figure 15.

In the model without a financial accelerator (dashed red line), a sudden increase in the level of consumption leads to an increase in output and inflation which the U.S. monetary authority dampens with a higher monetary policy rate. This increases the cost of capital and puts downward pressure on investment. However, in most business cycles, investment and consumption are positively correlated, which is part of the motivation for incorporating the financial accelerator. With the accelerator in place, on top of these effects, higher output and thus profits combined with a small reduction in the real value of firm's debt due to the first period's higher-than-expected inflation, increases firm net worth, making them less risky to lenders. Their external financing premium falls, helping to somewhat offset the increase in the cost of capital coming from the higher monetary policy rate.

In the case of a sustained increase in productivity, shown in the right hand column of Figure 17, the resulting increase in profitability is the primary factor increasing the net worth of firms. The unexpected increase in inflation is quite small and thus plays only a marginal role. Higher net worth makes firms more attractive to lenders, driving down their finance premium, thereby stimulating higher investment relative to the case where there is no financial accelerator mechanism present. 


\section{Figure 15:}

\section{Impact of the Financial Accelerator on Supply and Demand Effects in the United States}

Percent or percentage point deviation from steady-state baseline (Horizontal axis is in years)

With Financial Accelerator

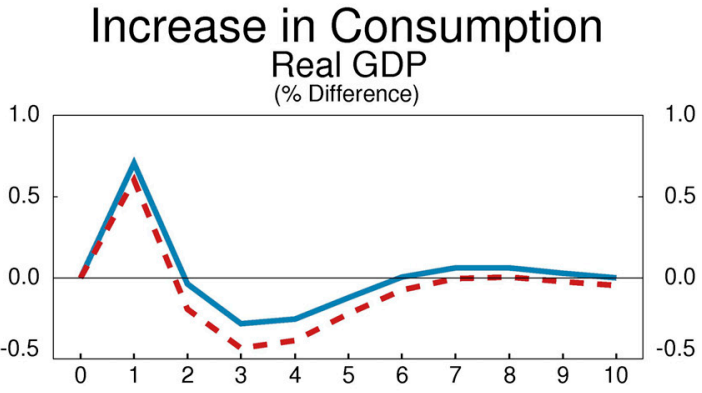

Real Investment

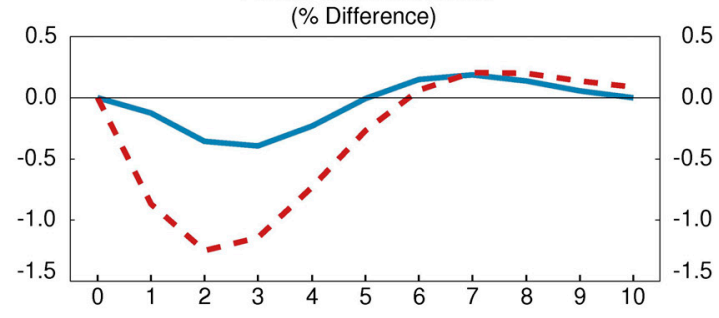

Nominal Interest Rate

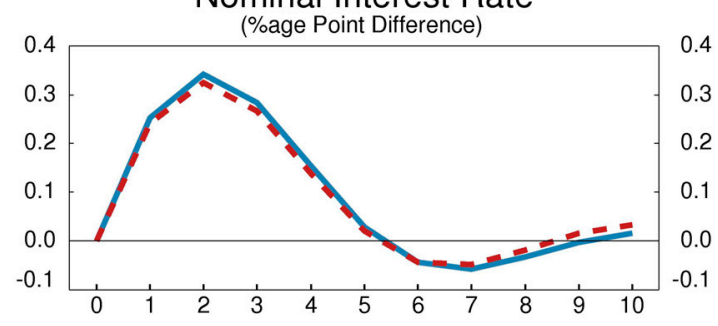

Firm's Financing Premium

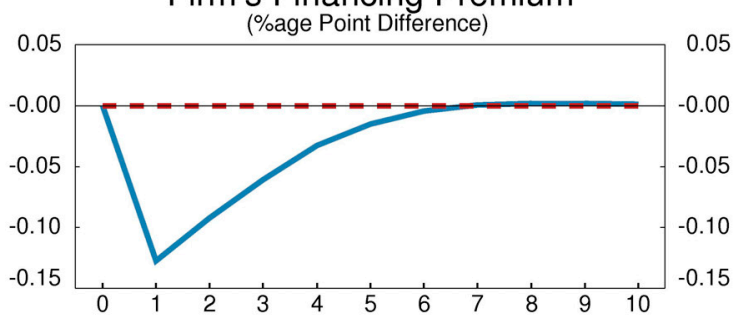

Inflation

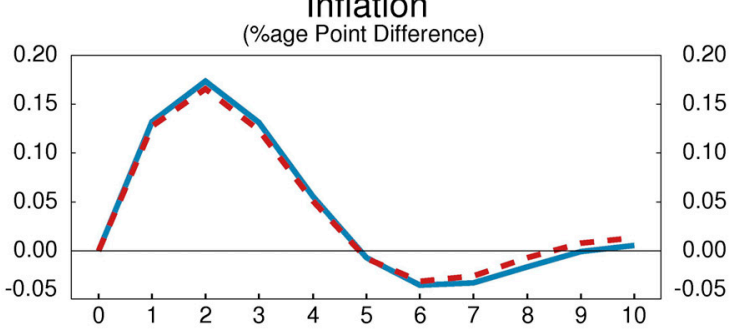

Without Financial Accelerator

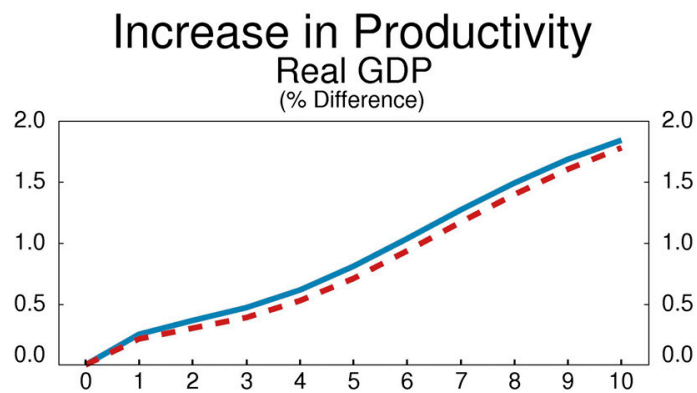

Real Investment

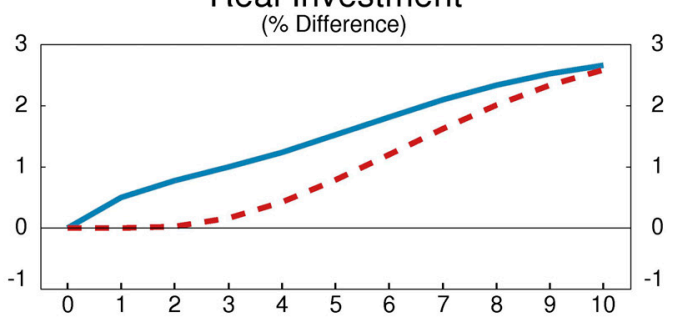

Nominal Interest Rate

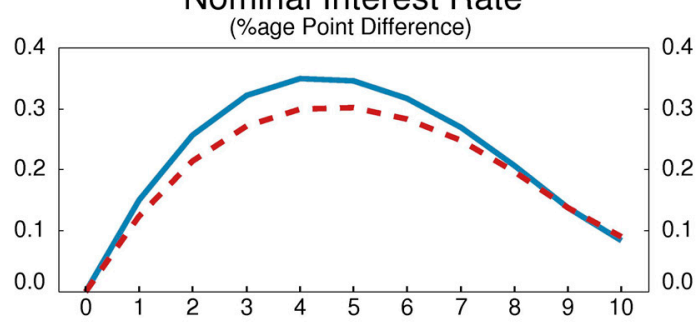

Firm's Financing Premium
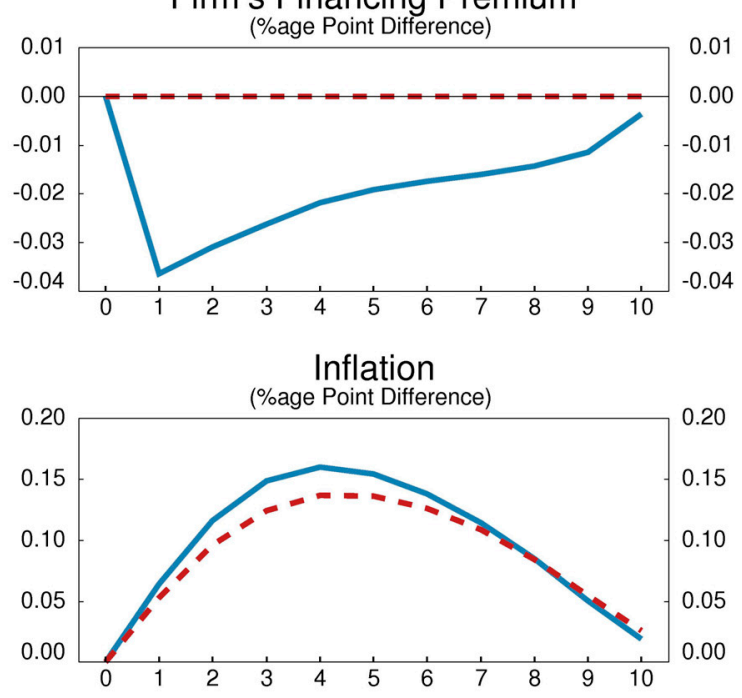


\section{Box III:}

\section{Impact of Leverage under an Increase in Borrower Riskiness}

Figure 16 shows the effects of different levels of steady-state leverage on economic outcomes when borrower riskiness increases. In all three cases considered, there is the same increase in the level of corporate borrower riskiness. The only exogenous factor being altered is the initial amount of leverage in the U.S. economy - a ratio of corporate debt relative to firms' net worth of either 1, 1.75, or 2.5. (A leverage ratio of 1 is the baseline calibration for all other shocks in this paper.)

Because entrepreneurs must pay their interest obligations on debt to avoid bankruptcy, an increase in leverage increases the cutoff rate for profitability that the entrepreneur has to achieve to avoid bankruptcy. Thus, the higher leverage is in the steady state, the more likely that the entrepreneur will default for a given increase in risk. This increased probability of default arising from different steady-state leverage ratios manifests itself in the rise in the external finance premium, which is larger when the steady-state leverage is higher. Thus, higher leverage ratios make the user cost of capital more sensitive and business investment more volatile in the presence of other shocks to the economy. The real interest rate is also slightly more volatile under higher steady-state leverage. 


\section{Figure 16:}

\section{The Impact of Leverage Under a Temporary Increase in Borrower Riskiness Effects in United States}

Percent or percentage point deviation from steady-state baseline
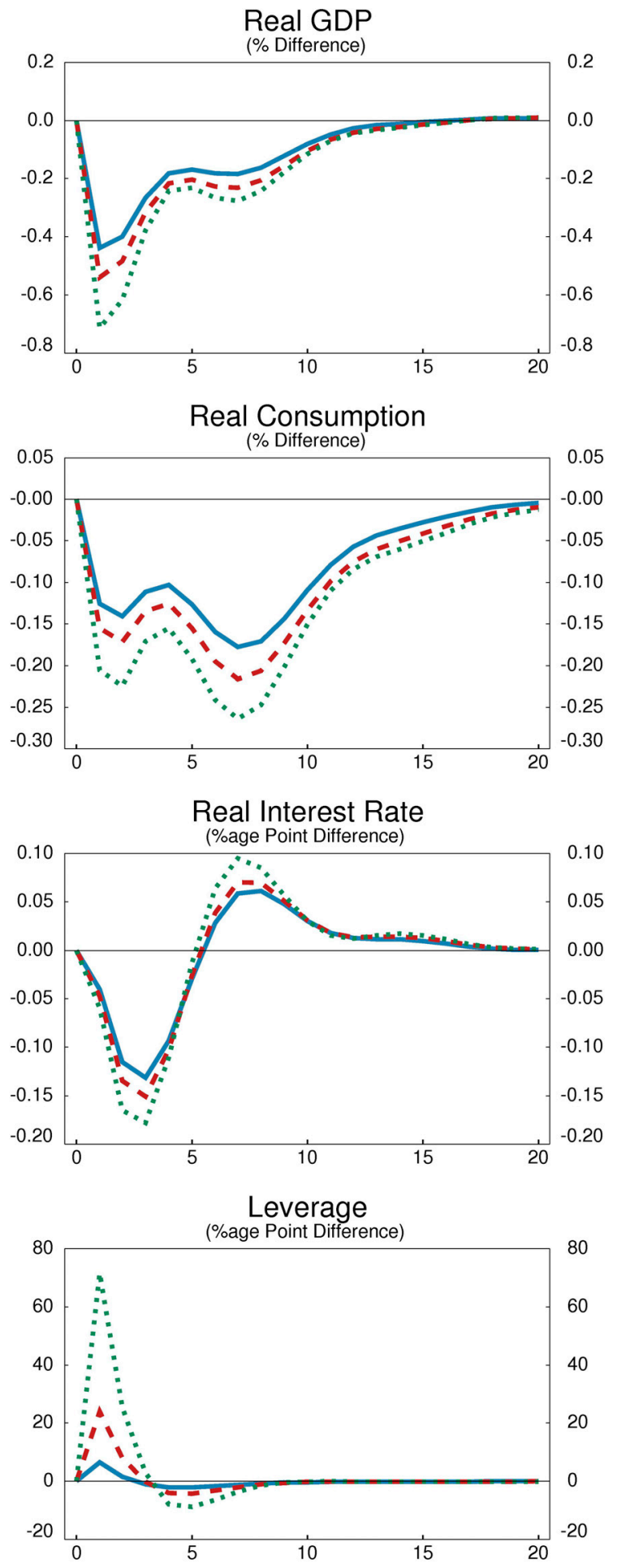
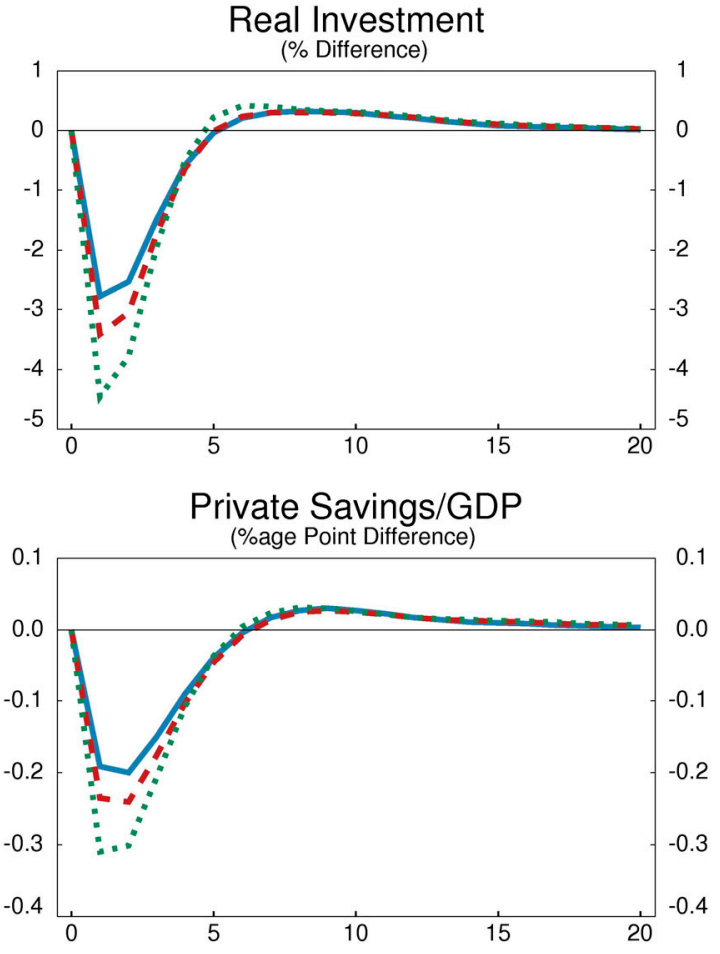

External Financing Premium

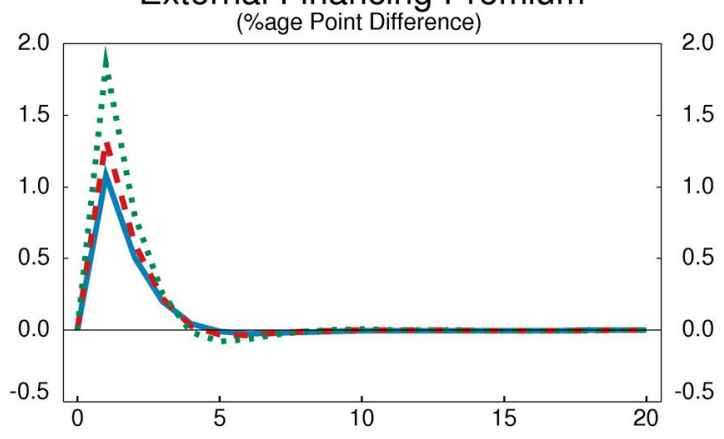

Net Worth/GDP

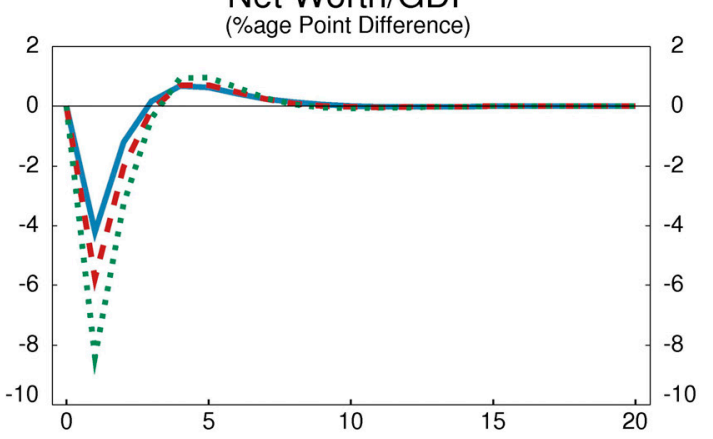




\section{Properties of Demand Shocks}

This section presents the effects of demand shocks in the United States and their impact on the rest of the world. Specifically, temporary shocks to private domestic demand, as well as a permanent shock to the rate of private saving are examined.

\section{A. Temporary Increase in Private Domestic Demand}

Figure 17 shows the effects of a one-year one percentage point increase in U.S. private consumption demand in tandem with a one-year four percentage point increase in private investment demand. In the short run, GDP increases by just over 1 percent and inflation rises by less than $1 / 4$ percentage point.

The higher level of investment accumulates into a higher stock of private capital, causing a persistent increase in output. To supply more goods, firms also increase their demand for labor, driving up wages. Higher wages combined with the higher cost of capital, due to the exogenous increase in investment demand, raise production costs. Firms pass marginal production cost increases to output prices, resulting in higher inflation.

In response to accelerating inflation, the monetary authority increases the policy interest rate in an effort to suppress demand and return inflation to target. The increase in the policy rate flows through to the real interest rate and exerts downward pressure on the demand for investment goods by increasing the cost of capital. The higher real interest rate affects the intertemporal consumption decision of households, enticing them to reduce consumption and temporarily increase saving. The fiscal authority reacts counter-cyclically to the pickup in real activity, reducing general transfers to households, improving the fiscal balance.

The increase in the real interest rate generates an appreciation in the real effective exchange rate through the uncovered interest parity condition. The appreciation decreases the price of U.S. imports, and increases the price of U.S. exports. This price effect, combined with the direct spillovers into imports from the increased demand for consumption and investment goods, results in a reduction in the trade balance. The weaker net export position helps reduce the demand on domestic productive capacity.

Figure 18 shows the effects on the rest of the world, where real GDP initially expands by roughly one-seventh the amount of the U.S. increase. There is an increase in U.S. demand for exports from all other regions, and households in those regions respond to higher import prices by substituting away from imports toward domestically produced goods. Higher import prices and the increase in the marginal cost of production from higher foreign and domestic demand result in a small increase in inflation. This prompts foreign monetary authorities to increase policy rates to reduce excess demand and dampen inflation pressures. 
Figure 17:

Temporary Increase in Private Domestic Demand

Effects in United States

Percent or percentage point deviation from steady-state baseline

(Horizontal axis is in years: $L R=$ Long Run)

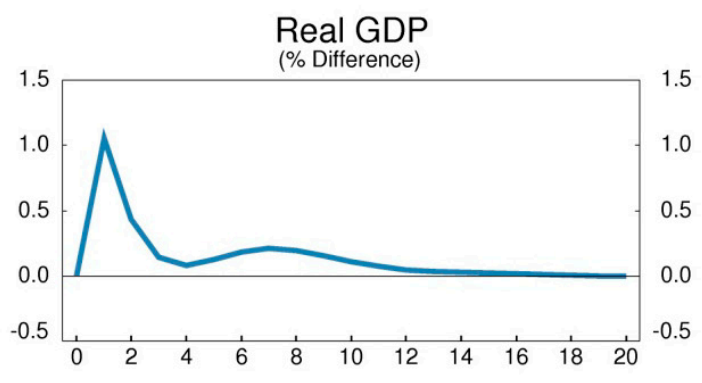

Real Private Consumption

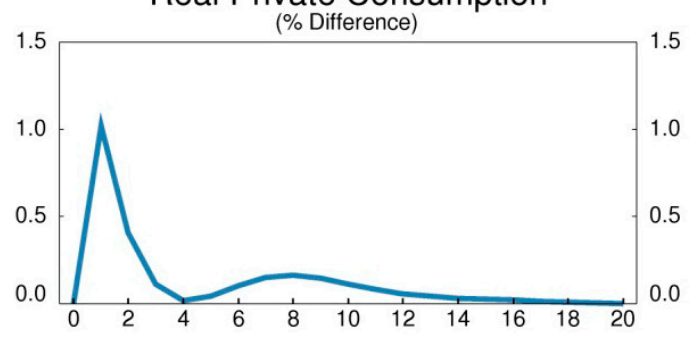

Real Exports

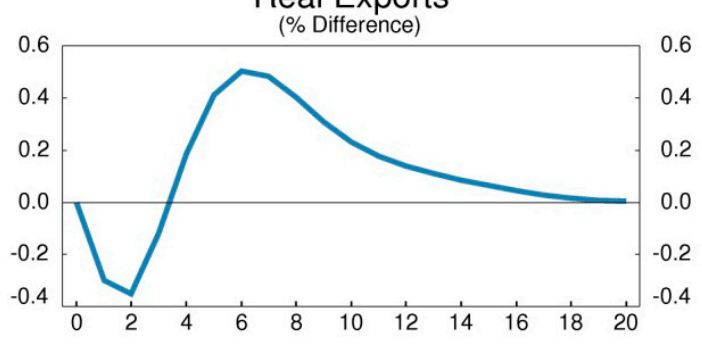

CPI Inflation

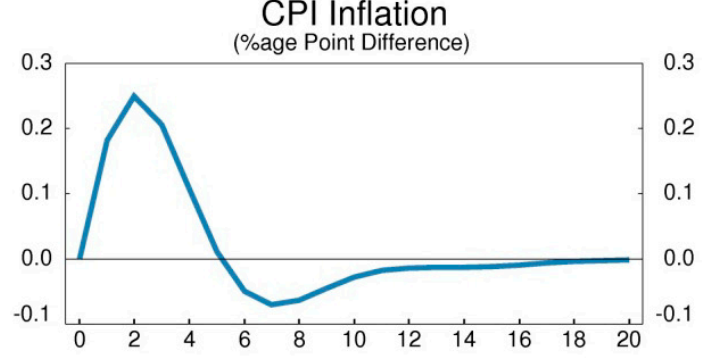

Trade Balance , Current Account - -

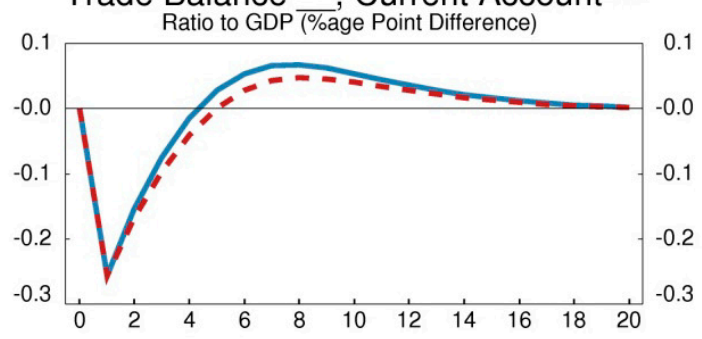

Government Surplus/GDP

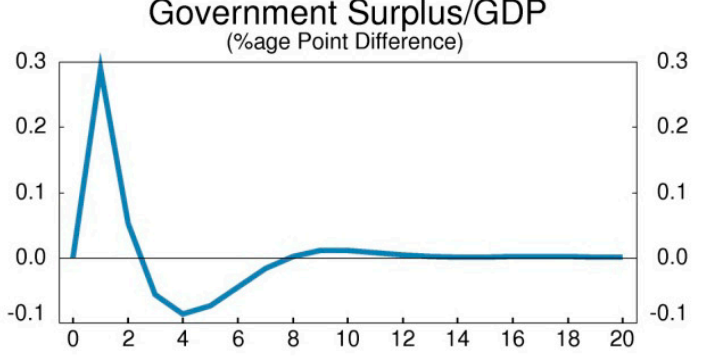

Real Private Investment

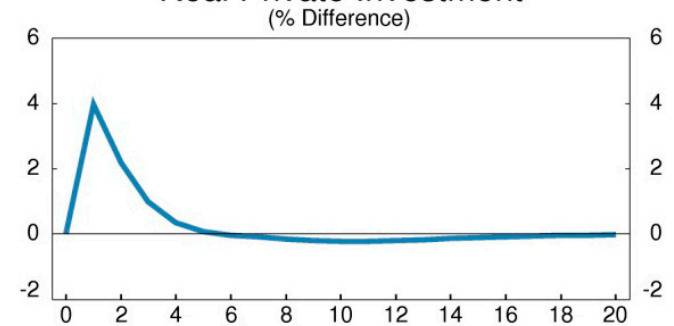

Real Imports

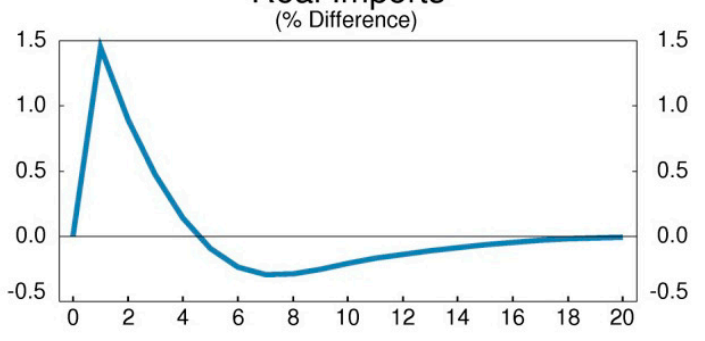

Nominal Interest Rate _ _ Real Interest Rate - -

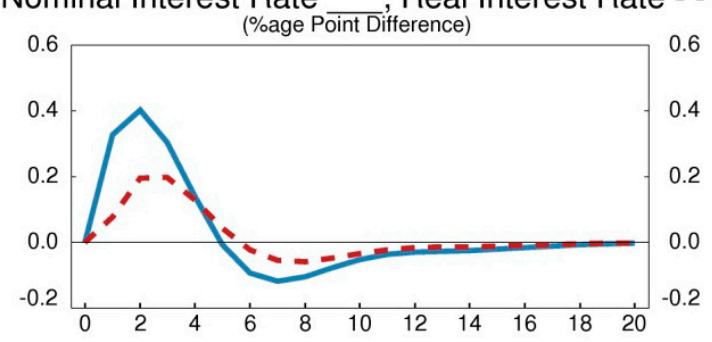

Real Effective Exchange Rate

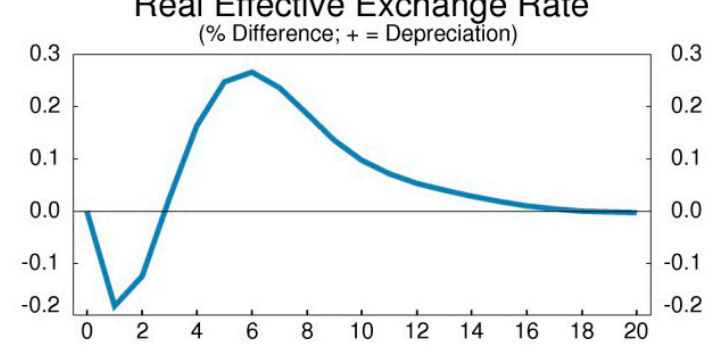


Figure 18:

Temporary Increase in Private Domestic Demand Effects in the Rest of the World

Percent or percentage point deviation from steady-state baseline

(Horizontal axis is in years: $L R=$ Long Run)
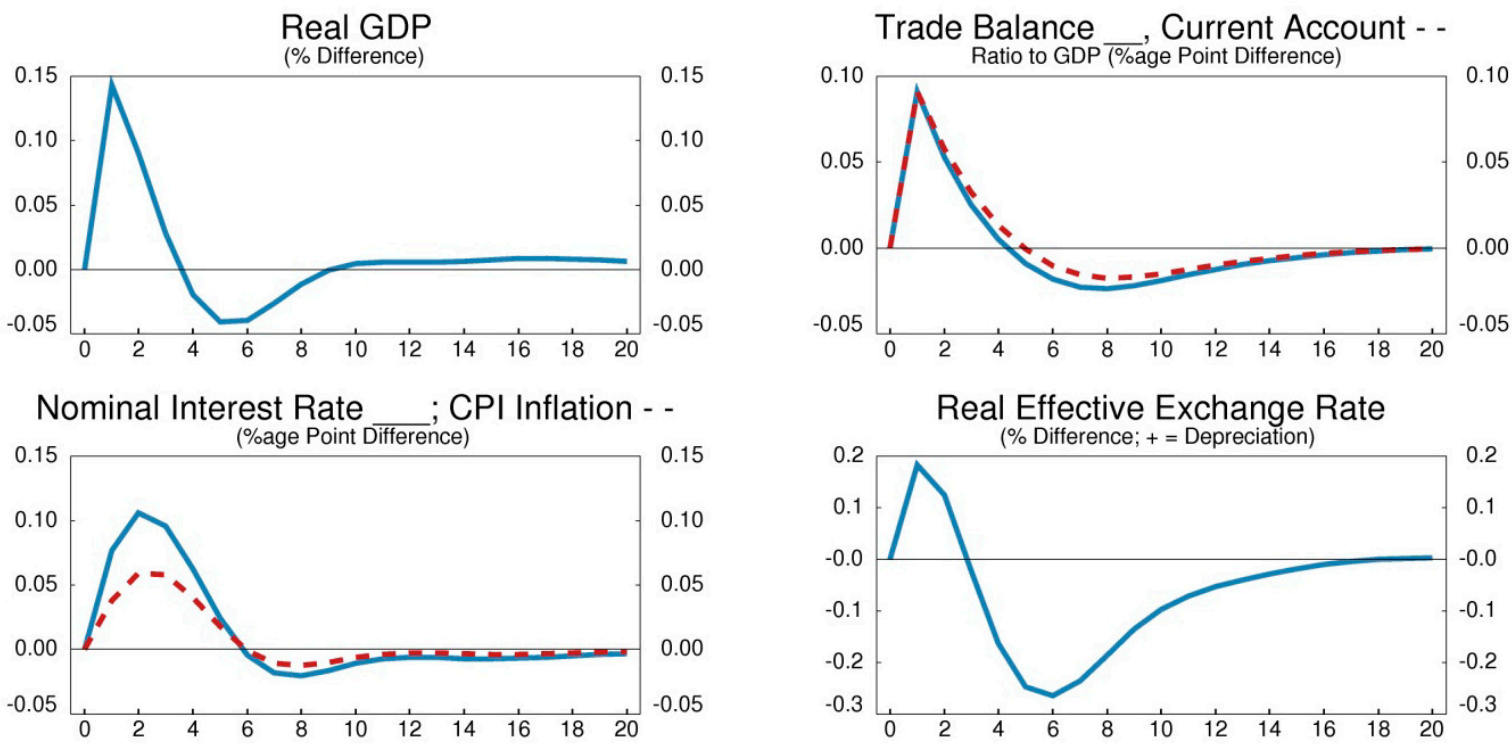

\section{B. Permanent Increase in Saving}

Figure 19 shows the effects of a permanent, one percentage point increase in the saving of OLG households in the United States. Although the short-run impact on activity is mildly negative, in the long run, the permanently higher savings rate raises real GDP by almost $1 / 4$ percent. Inflation declines initially and then takes several years to return to target as demand gradually converges to the new higher level of supply in the economy.

Households substitute away from consumption towards saving, thereby reducing demand for real consumption goods. The reduction in aggregate demand for consumption goods decreases real GDP in the first year by less than $1 / 4$ percent. To supply fewer consumption goods, firms decrease their demand for labor driving down wages. Higher savings also reduce the rental rate of capital. Lower marginal production costs in turn lead firms to decrease output prices, resulting in inflation falling by just under $1 / 4$ percentage point, after several years.

In response to the fall in inflation, the monetary authority reduces the policy interest rate in an effort to increase demand and return inflation to target. At the same time, households must accept a lower return as their increased saving reduces the equilibrium interest rate. The decrease in the policy rate and the downward pressure on the equilibrium interest rate flow through to the real interest rate, and exert downward pressure on the user cost of capital, 
thereby increasing demand for investment goods. Lower real interest rates also affect the intertemporal consumption decision of households, enticing them to increase consumption and unwind a little of their increased savings. The higher investment accumulates into a larger stock of capital, resulting in a permanently higher level of output and household income. In response to the increase in income and the higher level of wealth, real GDP increases in the long run by almost $1 / 2$ percent.

In the short run, the decrease in the real interest rate generates a depreciation in the real effective exchange rate through the uncovered interest parity condition. The depreciation increases the price of imports and decreases the price of U.S. exports. This price effect, combined with the spillover of the lower demand for consumption goods into real imports, results in an increase in the trade balance. The stronger net export position absorbs some of the increase in domestic productive capacity. In addition, the increase in demand for foreign assets improves the net foreign asset position and results in a permanent improvement in the current account. In the long run, there is pressure for the real effective exchange rate to appreciate given the higher equilibrium level of foreign assets.

The rest of the world, as shown in Figure 20, experiences a reduction in the demand for its exports and responds to lower import prices by substituting towards imports and away from domestically produced goods. This price effect, combined with the direct spillover from lower foreign demand, initially reduces real GDP. Lower import prices and the decrease in the marginal cost of production from lower foreign and domestic demand also result in a small initial decline in inflation. The increase in global saving eventually translates into a lower global equilibrium real interest rate. The resulting reduction in the user cost of capital permanently raises investment and thus productive capacity, boosting real GDP permanently in the long run. 
Figure 19:

Permanent Increase in Private Savings

Effects in United States

Percent or percentage point deviation from steady-state baseline

(Horizontal axis is in years: $L R=$ Long Run)

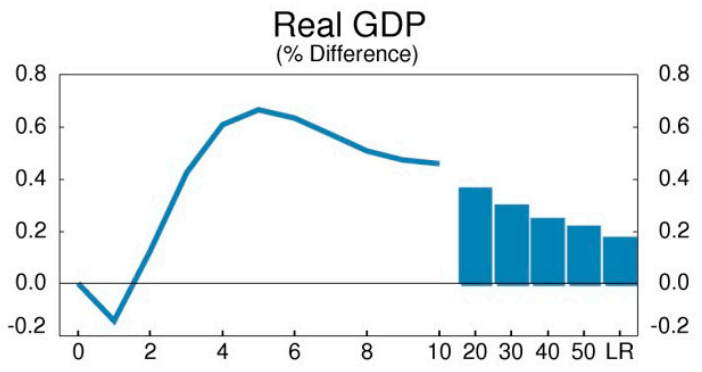

Real Private Consumption

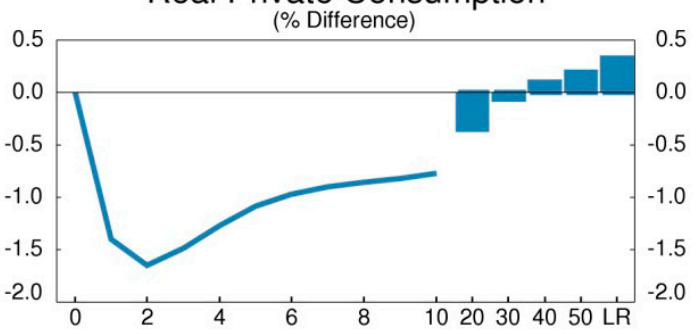

CPI Inflation

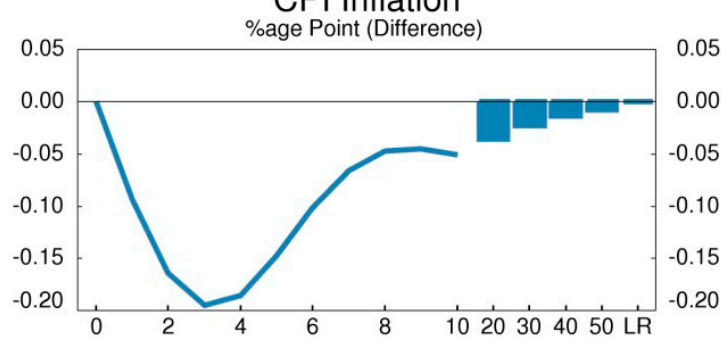

Capital Stock

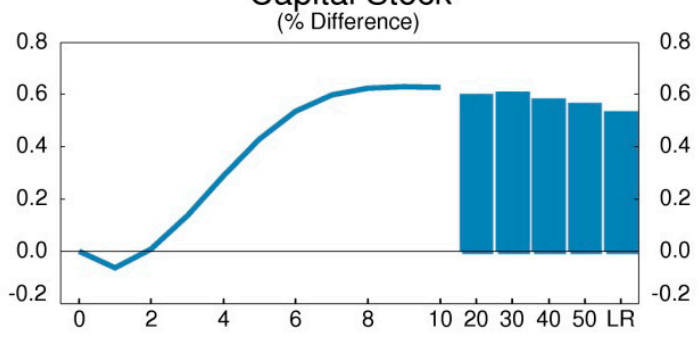

Current Account/GDP

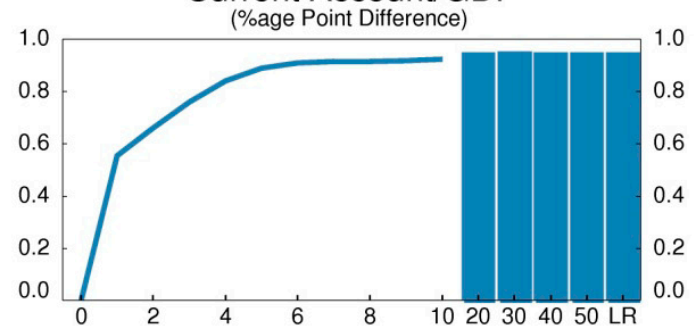

Private Savings/GDP

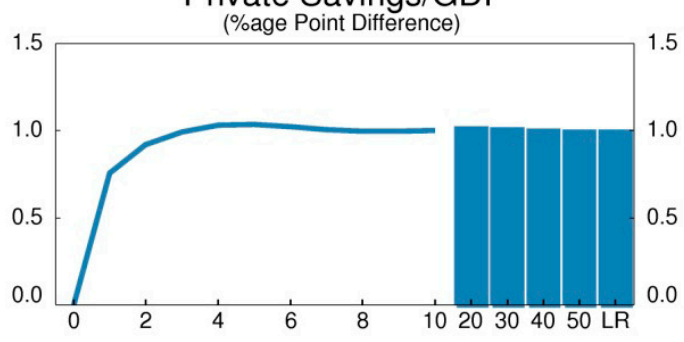

Real Private Investment

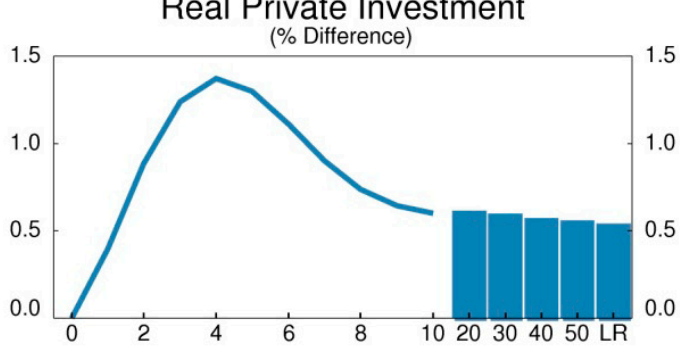

Real Interest Rate

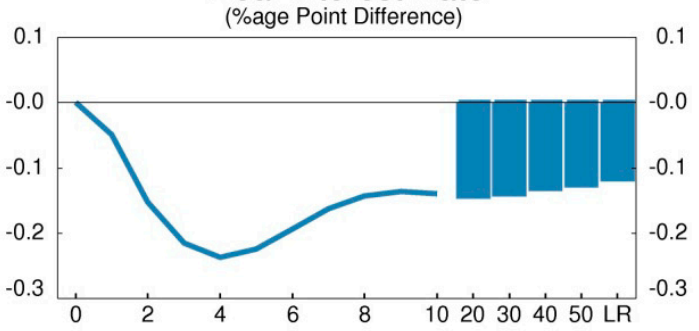

Labor Supply

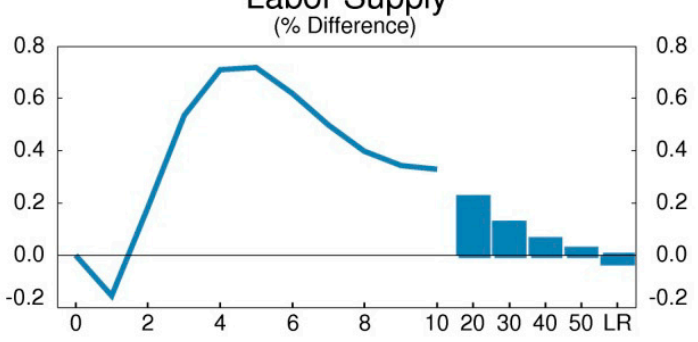

Real Effective Exchange Rate

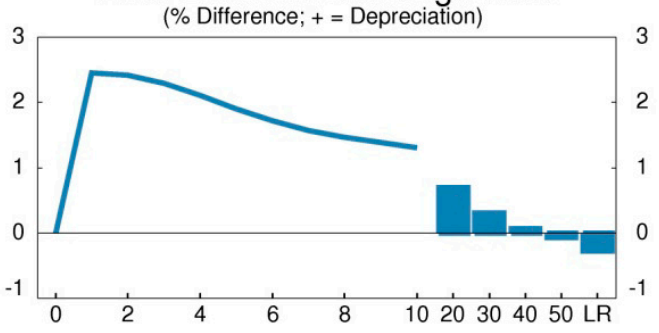


Figure 20:

Permanent Increase in Private Savings

Effects in the Rest of the World

Percent or percentage point deviation from steady-state baseline

(Horizontal axis is in years: $L R=$ Long Run)
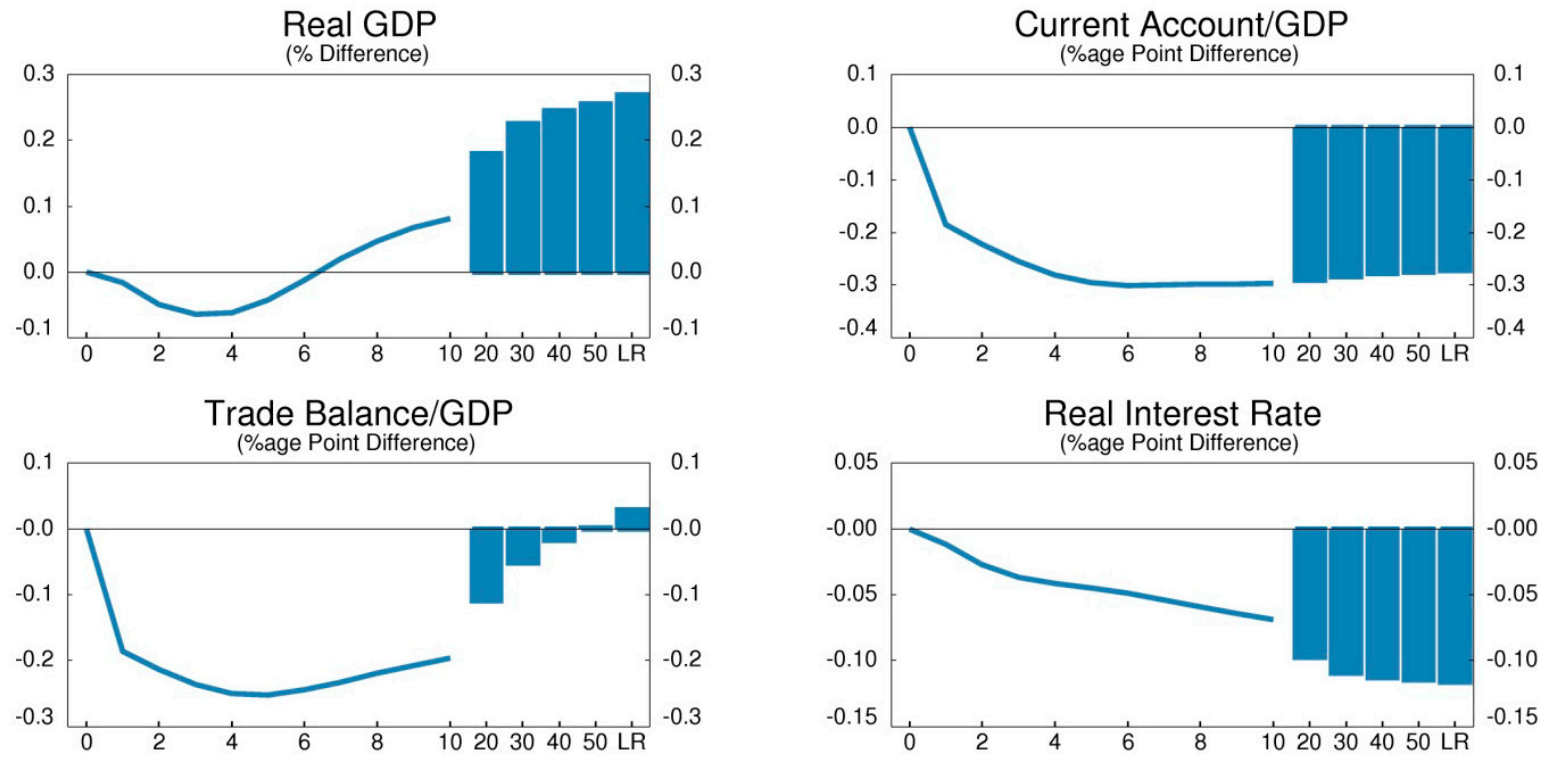

CPI Inflation

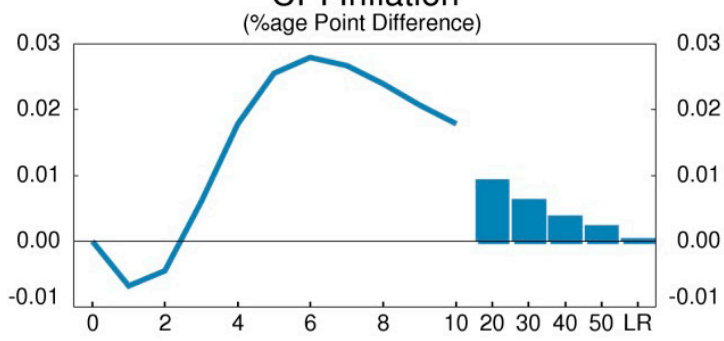

Real Effective Exchange Rate

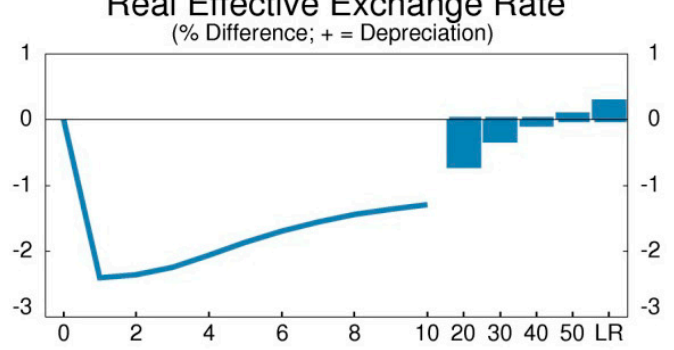




\section{Properties of Supply Shocks}

This section presents the effects of supply shocks in the United States and their impact on the rest of the world. A range of permanent changes in productivity are examined, including a permanent change in the level of labor-augmenting productivity in the tradable and nontradable intermediate goods sectors, as well as anticipated and unanticipated increases in the growth rate of labor-augmenting productivity. In addition, this section examines permanent decreases in the markups in real wages as well as and intermediate goods.

\section{A. Permanent Increase in the Level of Labor-Augmenting Productivity in Intermediate Goods Production, and the Balassa-Samuelsson Effect}

Figure 21 shows the effects of a one percent increase in the level of labor augmenting productivity in both the tradable and nontradable intermediate goods sectors, as well as isolated in the tradable intermediate goods sector in the United States. The size of the increase in tradable sector productivity is calibrated to result in the same increase in GDP as the one percent increase in economy-wide productivity.

Higher productivity raises the marginal products of capital and labor, thereby increasing the demand for these factors of production. To entice households to supply more labor and capital, firms offer a higher real wage and real rental rate on capital. This results in a large increase in the income of households and, consequently, private domestic demand.

The increase in productivity more than compensates for higher wages and capital costs, so overall marginal production costs decline. This leads firms to decrease output prices, and inflation falls slightly in the short run. In response, the monetary authority lowers the policy interest rate in an effort to increase demand sufficiently to return inflation to target. The decline in the policy rate flows through to the real interest rate and exerts upward pressure on the demand for investment goods by decreasing the user cost of capital, and affects the intertemporal consumption decision of households, resulting in an increase in consumption and a temporary decrease in private saving. The fiscal authority reacts counter-cyclically to the pickup in real activity by reducing general transfers to households, temporarily improving the fiscal balance.

The impact on the real effective exchange rate depends on which sector the change in productivity originates. An increase in the level of productivity in all intermediate goods sectors reduces marginal production costs, which reduces output prices and exerts downward pressure on inflation. Since productivity is increasing in all sectors, the relative price of U.S. tradable goods does not fall. To sell some of the additional output to the rest of the world, the real effective exchange rate depreciates to increase the competiveness of U.S. exports abroad.

An increase in the level of productivity in the tradable intermediate goods sector alone reduces the marginal production costs and tradable intermediate goods prices. It also means 
that nominal wages will rise in the sector due to higher productivity. In GIMF, labor is mobile across sectors but not countries. Therefore, the increase in nominal wages in the tradable intermediate goods sector must be matched by an increase in nominal wages in the nontradable intermediate goods sector. However, in the absence of a productivity improvement in this sector, firms must raise the prices of nontradable intermediate goods, further amplifying the decline in the relative price of tradable intermediate goods. Since the elasticities of substitution between domestic and imported goods are above unity in the domestic and foreign economies, this shift in relative prices results in an appreciation in the real effective exchange rate to maintain external balance. This is commonly known as the Balassa-Samuelson effect.

In the long run, under both types of an increase in productivity, the current account shifts to a small deficit and net foreign assets decline. Essentially, domestic households do not want to supply all of the savings required to finance the increase in the domestic capital stock, so some of the increase is financed externally.

Turning to the impact on the rest of the world, increases in productivity (for example, from an improved technological process for production) will spill over to some degree to other regions of the world. Therefore, the increase in productivity in the United States spills over into the level of labor augmenting productivity in both the tradable and nontradable intermediate goods sectors in the rest of the world. At the same time, the increase in the demand for investment goods outpaces the supply of saving and temporarily puts upward pressure on the world real interest rate by a small amount, slightly crowding out private demand in the rest of the world. This results in similar effects observed in the United States, with an increase in real GDP and generally the same dynamics across all the economies in the rest of the world, as shown in Figure 22. 
Figure 21:

Permanent Increase in the Level of Labor-Augmenting Productivity Effects in United States

Percent or percentage point deviation from steady-state baseline

(Horizontal axis is in years: $L R=$ Long Run)

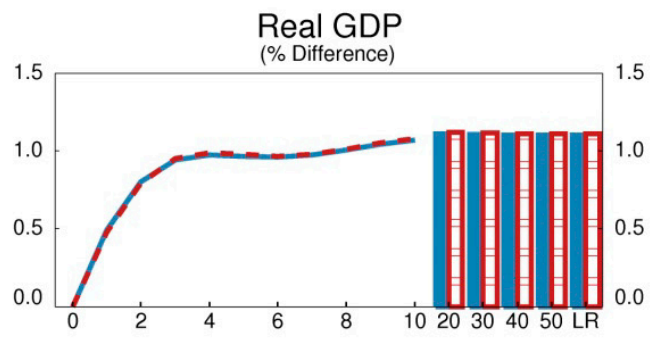

Real Private Consumption

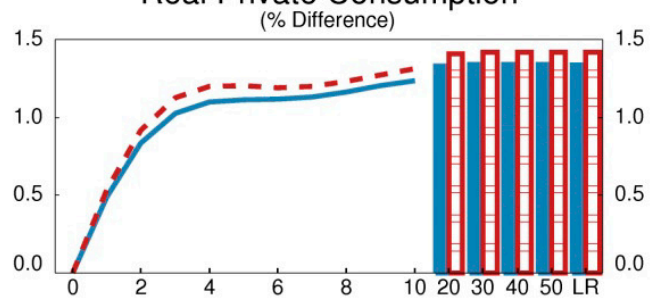

CPI Inflation

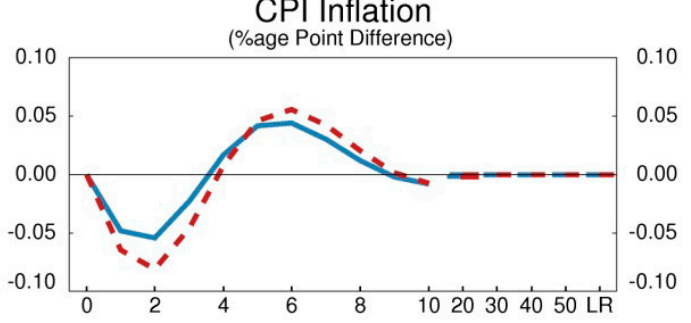

\section{Capital Stock}

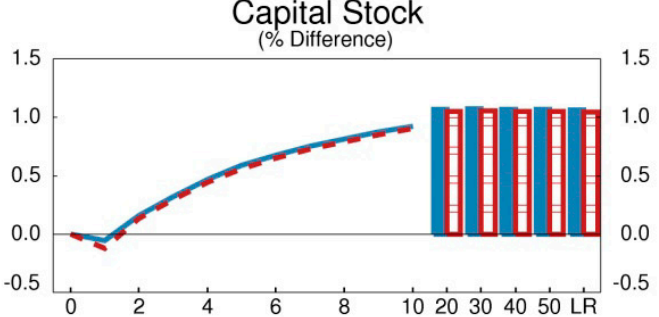

Current Account/GDP

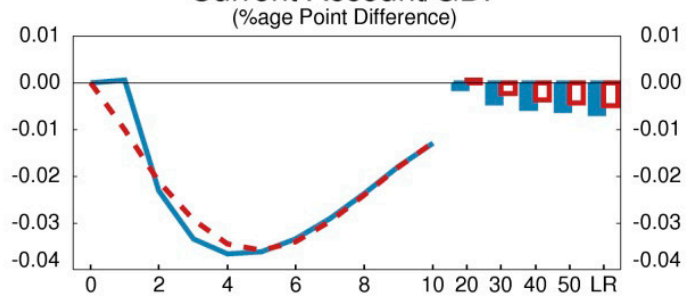

Tradable Sector Increase

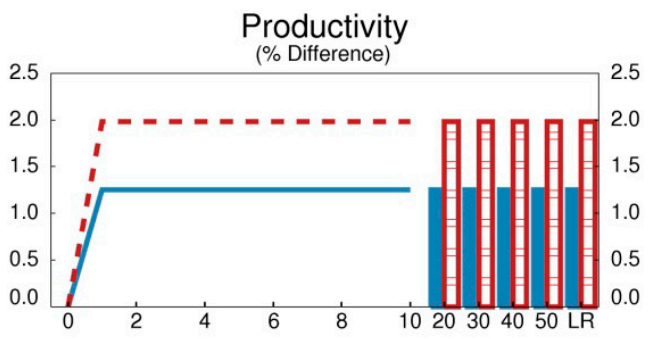

Real Private Investment
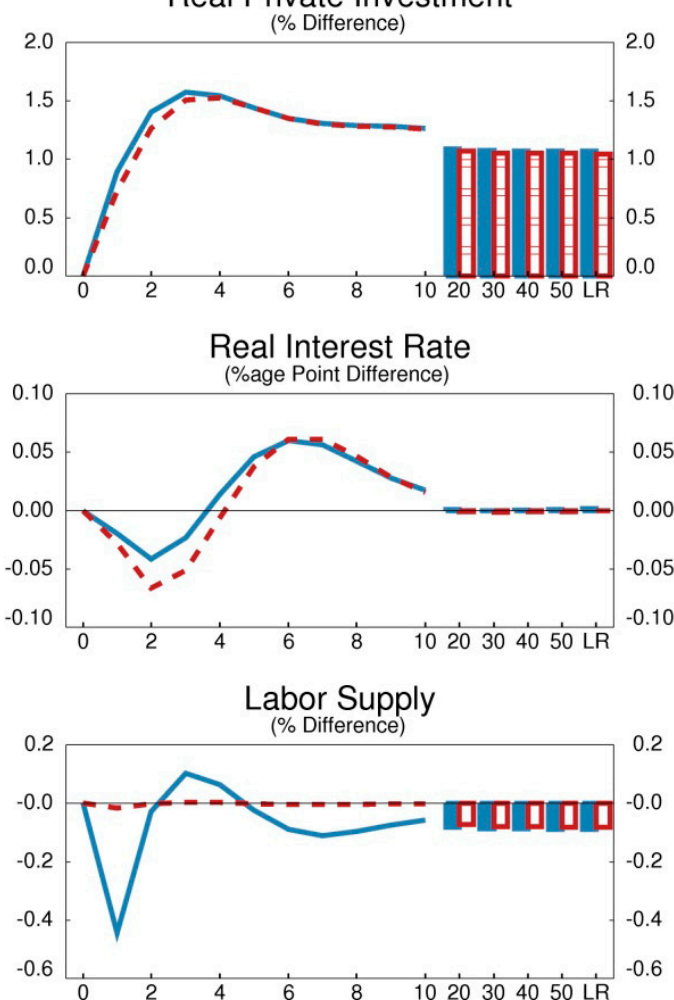

Real Effective Exchange Rate

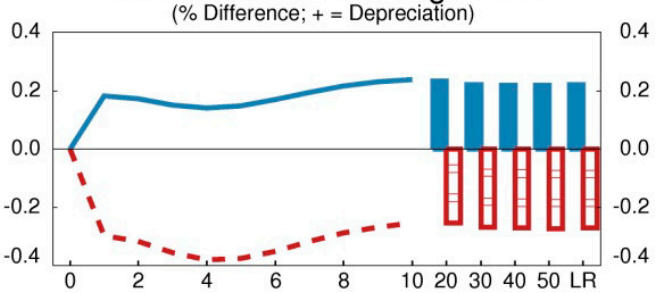


Figure 22:

Permanent Increase in the Level of Labor-Augmenting Productivity Effects in the Rest of the World

Percent or percentage point deviation from steady-state baseline (Horizontal axis is in years: LR = Long Run)
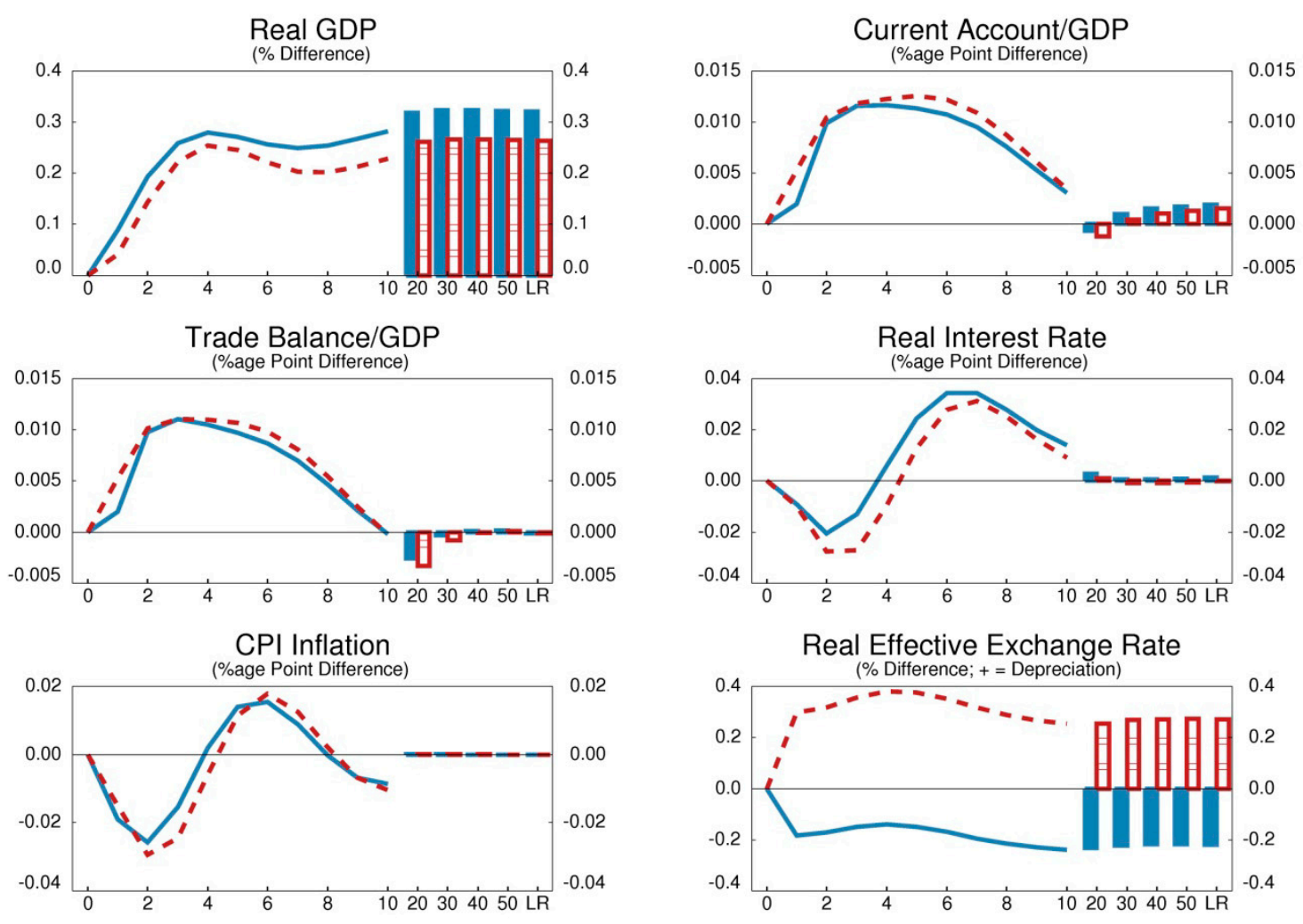


\section{B. Temporary 10-Year Increase in the Growth Rate of Labor-Augmenting Productivity in All Intermediate Goods Production}

Figure 23 shows the effects of a ten-year anticipated increase versus a ten-year unanticipated increase in the growth rate of economy-wide labor-augmenting productivity in the United States. The size of the increase in productivity is calibrated to increase the level of real GDP each year by just under $1 / 4$ percent, which results in a permanent increase in the level of real GDP by roughly 2 percent at the end of ten years.

The increase in productivity results in an increase in the marginal products of capital and labor, thereby increasing the demand for those factors of production. To encourage households to supply more labor and capital, firms increase the real wage and the real rental rate on capital, resulting in a large increase in the income of households. This translates into an increase in private domestic demand.

There are two competing effects on output prices. First, the increase in productivity places downward pressure on marginal production costs and thus firms' output prices. Second, households perceive a permanent increase in their future incomes in the anticipated scenario, encouraging them to increase spending today to smooth lifetime consumption. To supply more goods, firms increase their demand for labor and capital, driving up production costs, and thus output prices. The overall impact on inflation will depend on whether the increase in the growth rate of household incomes is anticipated.

If households do not perceive the future increases in productivity, they do not expect the growth in their income stream, and consumption does not increase as much initially. In this case, the decrease in the marginal cost from the increase in productivity dominates the impact on inflation, resulting in a small decline in inflation in the short run.

If households do perceive the future increase in productivity, they try to smooth their lifetime consumption by increasing spending more in the short run. In this case, the impact from higher demand dominates, and inflation rises in the short run by less than $1 / 4$ percentage point.

In response to the increase in inflation in the anticipated case, the monetary authority increases the policy interest rate in an effort to decrease demand sufficiently to return inflation to target. The increase in the policy rate flows through to the real interest rate and exerts downward pressure on the demand for investment goods by increasing the user cost of capital, and affects the intertemporal consumption decision of households, enticing them to decrease consumption and temporarily increase private saving. The fiscal authority reacts counter-cyclically to the pickup in real activity by reducing general transfers to households, temporarily improving the fiscal balance. 
When households do not anticipate a permanent future increase in productivity, the opposite mechanisms are in play. Inflation falls, thus the monetary authority reduces the policy interest rate, with the opposite effect of the anticipated case. The fiscal authority attempts to stimulate real activity by increasing general transfers to households.

The direction of the interest rate movement determines the short-run impact on the real effective exchange rate. The anticipated increase in the growth rate of productivity results in a higher real interest rate, and consequently, currency appreciation through uncovered interest parity. The appreciation reduces the price of imports and raises the price of U.S. exports, with these prices effects reducing the trade balance and the current account. These price effects are amplified by the increase in demand spilling over into imports. In the unanticipated case, these short-run exchange rate, trade balance, and current account outcomes are reversed. In the long run, however, the real effective exchange rate depreciates whether the productivity increase is anticipated or not. Because productivity is increasing in all sectors, the relative price of U.S. tradable goods is not falling. To permanently raise external demand for the increased U.S. output, the real effective exchange rate must depreciate to increase the competiveness of U.S. exports abroad.

In the rest of the world, a fraction of the increase in productivity spills over into the level of labor augmenting productivity in both the tradable and nontradable goods sectors in other regions. This results in similar effects observed in the United States, as shown in Figure 24. 
Figure 23:

Temporary Increase in Labor Augmenting Productivity Growth Rate Effects in United States

Percent or percentage point deviation from steady-state baseline

(Horizontal axis is in years: $L R=$ Long Run)

___ Unanticipated Productivity Growth
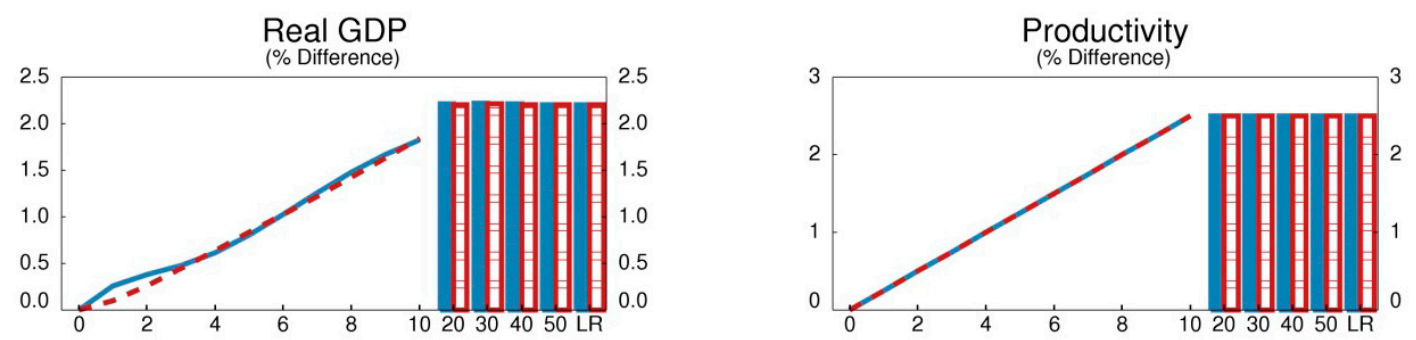

Real Private Consumption

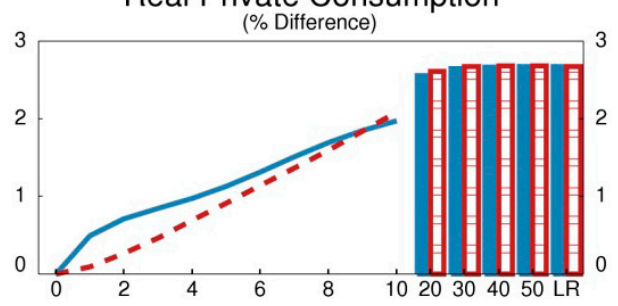

Real Private Investment

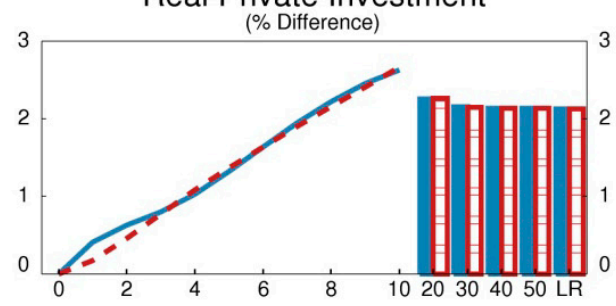

CPI Inflation

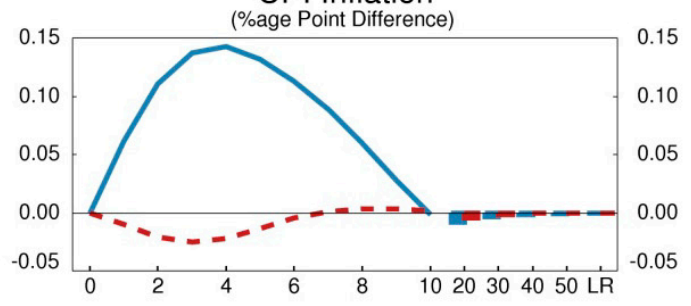

Real Interest Rate

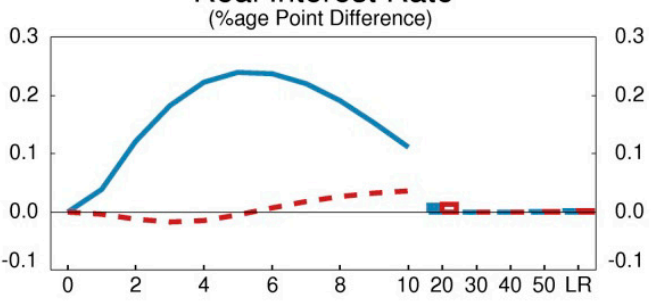

Capital Stock
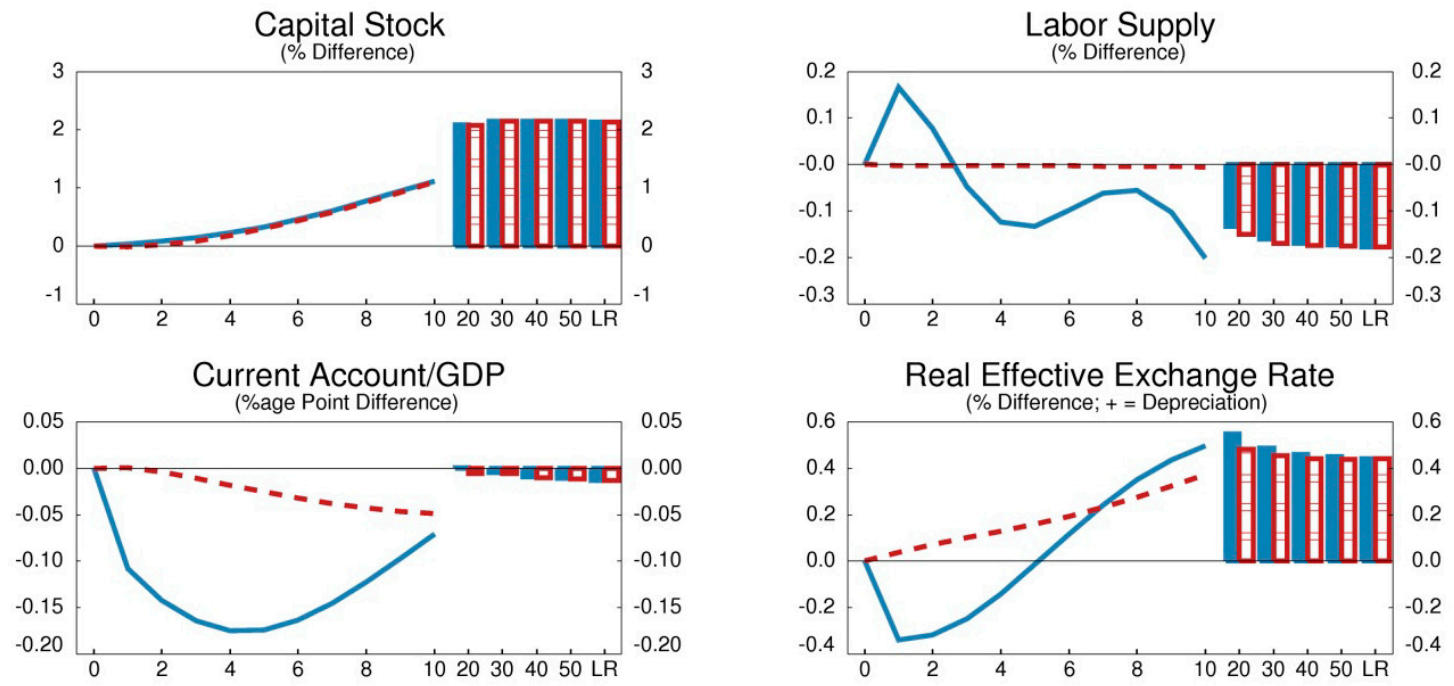
Figure 24:

Temporary Increase in Labor Augmenting Productivity Growth Rate Effects in the Rest of the World

Percent or percentage point deviation from steady-state baseline (Horizontal axis is in years: LR = Long Run)
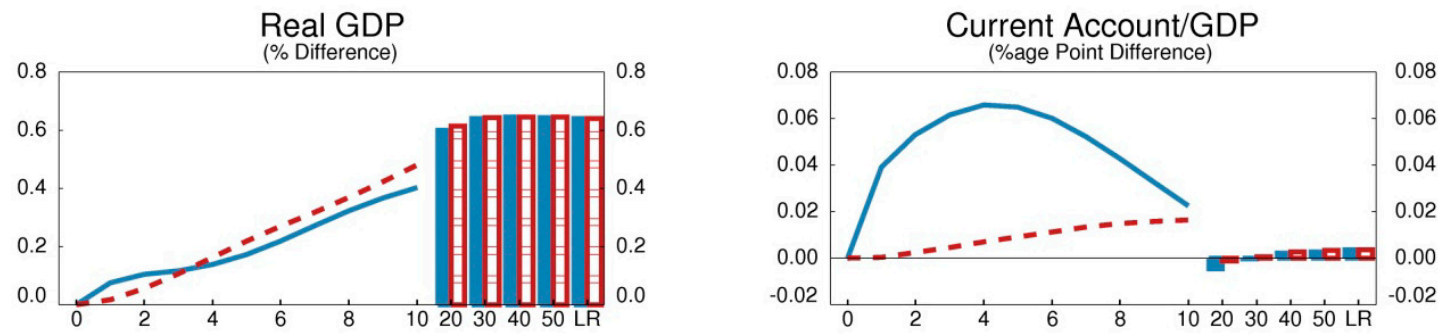

Trade Balance/GDP

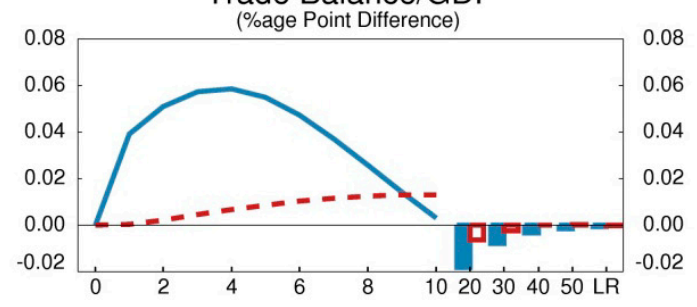

Real Interest Rate

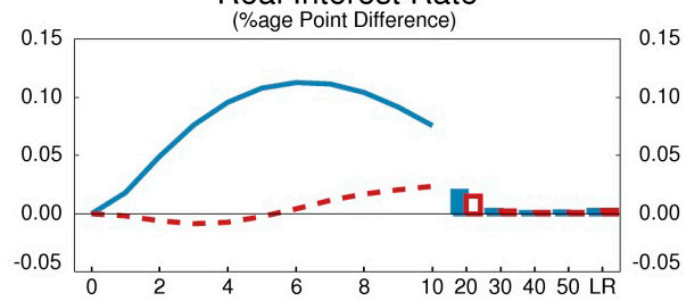

CPI Inflation

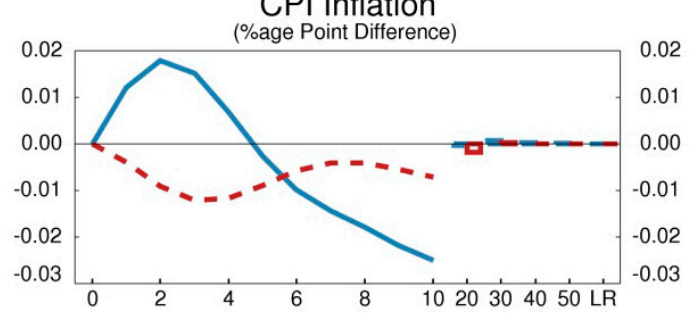

Real Effective Exchange Rate

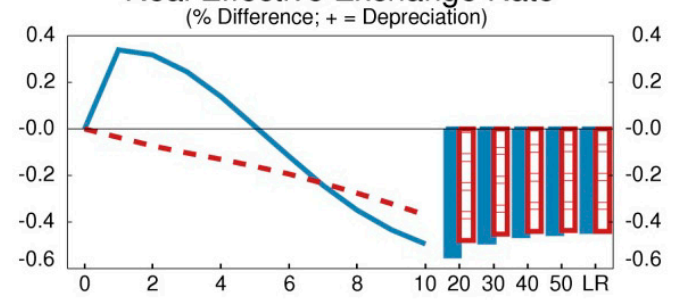




\section{Permanent Increase in Competition in the Labor Market that Decreases the Markup in Real Wages}

Figure 25 shows the effects of a permanent increase in labor market competition that reduces the markup on wages by five percentage points in the United States. In the long run, real GDP increases almost $1 \frac{1}{2}$ percent above baseline. In the short-run, a lower markup imparts some mild disinflationary pressure.

Increasing competition in the labor market that reduces the wage markup diminishes the wedge between the wage paid by producers and that demanded by households. Firms respond to the lower labor costs by permanently employing more labor and renting more capital. In the long run, the increase in labor supply is large enough to more than offset the impact on income from the lower wage rate, leading to an increase in labor income and thus human wealth. In response to higher human wealth, households permanently save and consume more. In the long run, the increase in demand for consumption and investment goods aligns with the economy's increase productive capacity, and real GDP is permanently higher.

The lower marginal cost of production allows firms to lower output prices, resulting in a mild decline in inflation. In response, the monetary authority decreases the policy interest rate to increase demand and return inflation to target. The fiscal authority reacts counter-cyclically to the pickup in real activity by reducing general transfers to households, temporarily improving the fiscal balance.

In the short-run, the decrease in nominal interest rates generates a depreciation of the real effective exchange rate through the uncovered interest parity condition. The depreciation increases the price of imports and decreases the price of U.S. exports. In the long run, the reduction in the wage markup has an identical exchange rate impact as an economy-wide increase in productivity. The real effective exchange rate must depreciate so that the higher level of U.S. exports will be absorbed by the rest of the world.

The permanently higher level of U.S. saving is larger than the increase in the desired capital stock, and consequently, the long-run real interest rate declines to equilibrate the supply and demand for savings.

Figure 26 shows the outcome as the rest of the world responds to lower import prices by substituting towards imports and away from domestically produced goods. Real GDP initially declines slightly. Eventually, however, the lower world real interest rate, resulting from higher saving in the United States, exerts upward pressure on the demand for investment goods through a lower user cost of capital, and entices households to increase consumption and decrease saving. Thus, the initial fall in real GDP from a lower trade balance is offset after several years by the increase in domestic demand from a lower real interest rate and results in a permanently higher level of output. 
Figure 25:

Permanent Increase in Competition that Decreases the Wage Markup Effects in United States

Percent or percentage point deviation from steady-state baseline

(Horizontal axis is in years: LR = Long Run)

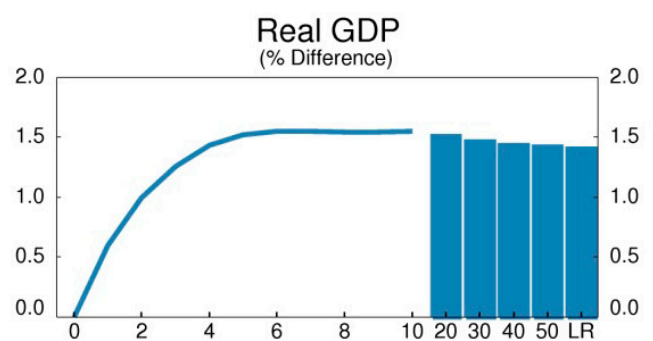

Real Private Consumption

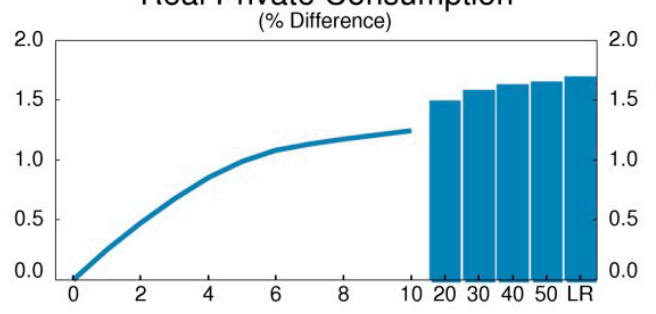

CPI Inflation

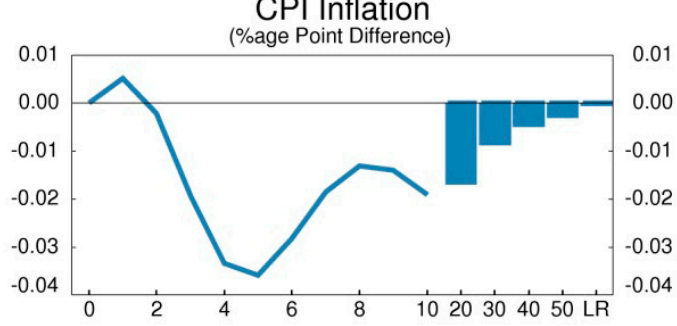

Capital Stock

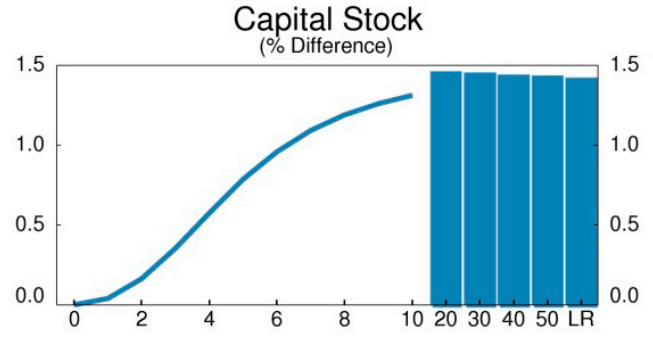

Current Account/GDP

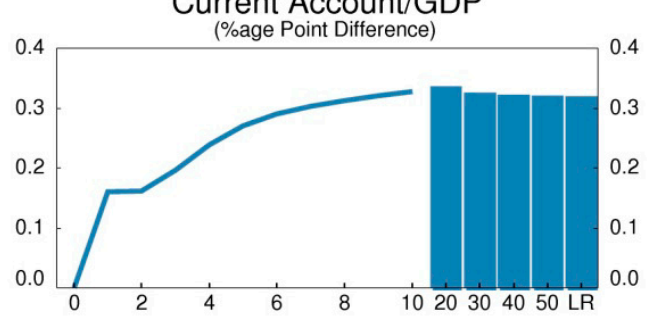

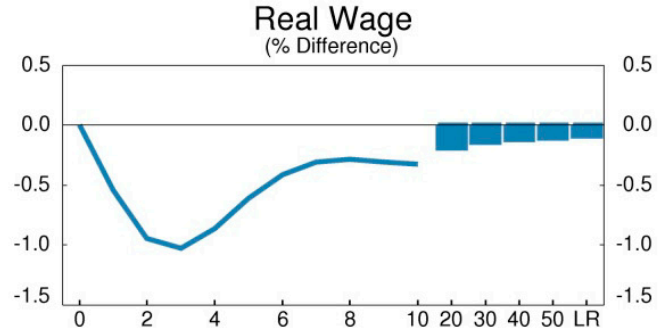

Real Private Investment
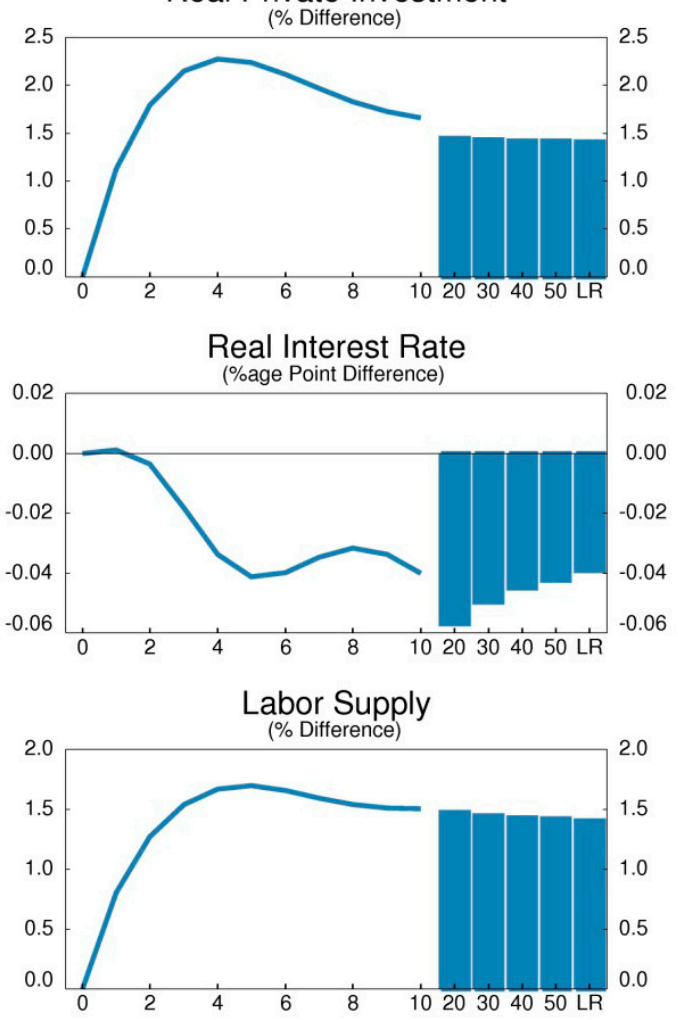

Real Effective Exchange Rate

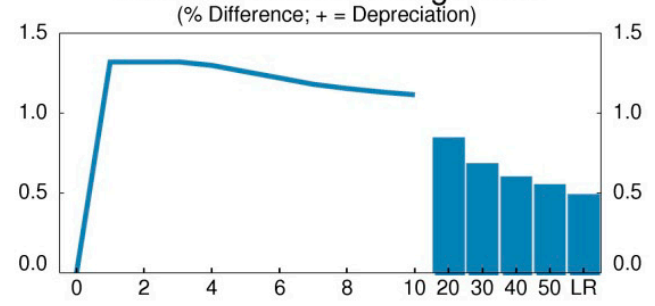


Figure 26:

\section{Permanent Increase in Competition that Decreases the Wage Markup Effects in the Rest of the World \\ Percent or percentage point deviation from steady-state baseline \\ (Horizontal axis is in years: $L R=$ Long Run)}
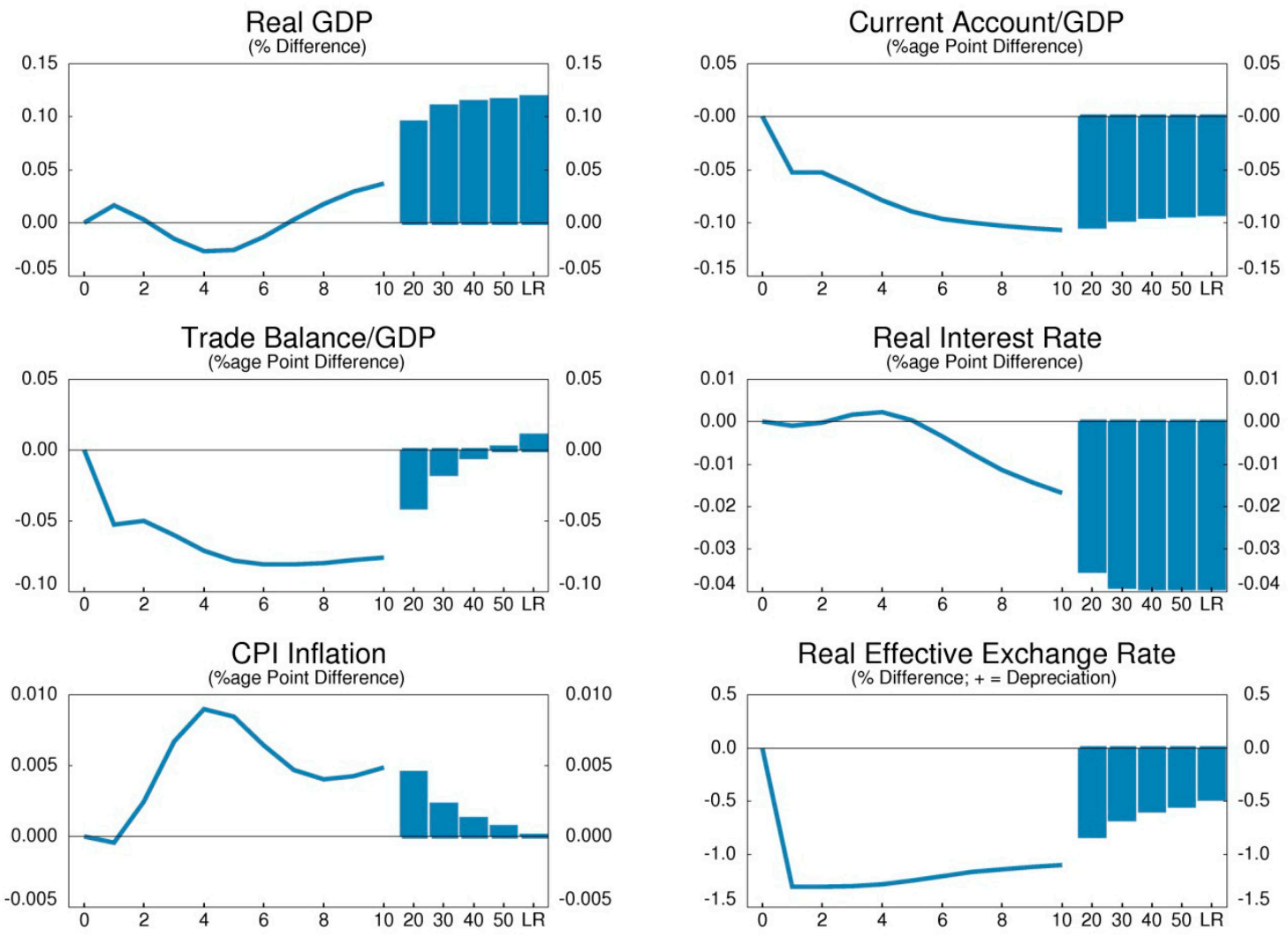

\section{Permanent Increase in Competition that Decreases Intermediate Goods Price Markups}

Figure 27 shows the effects of a permanent increase in competition that reduces the markup over marginal cost in the U.S. tradable and nontradable goods sectors by five percentage points. In the long-run, the increase in real GDP is roughly 2 or 3 percent, depending on the sector in which the markup declines. Despite the decline in output price inflation in the sector experiencing the increased competition, overall CPI inflation rises slightly owing to increased demand for both investment and consumption goods.

The decline in the markup results from an increase in competition among firms in goods markets, which is reflected in higher demand for both capital and labor. This results in higher labor and investment income for households. The increased output initially drives down prices in the expanding sector, raising the implicit return to labor, which induces households to further boost labor supply. Higher incomes permanently raise household consumption. The expansion in the economy's supply capacity is roughly matched with permanently higher 
demand for investment and consumption goods, which raises real GDP gradually over ten years to 2 percent above baseline in the case of increased competition in the tradable goods sector, and 3 percent above baseline in the case of increased competition in the nontradable goods sector. Although increased competition leads firms in the affected sector to slow the rate of increase in their output prices, along the adjustment path to the new equilibrium, overall demand in the economy exceeds supply temporarily, and results in slightly higher CPI inflation, peaking in year 5 at approximately $1 / 4$ percentage point. The lower rate of price inflation in the affected sector is evident in the decline in that sector's relative price.

In response to the increase in inflation, the monetary authority raises the policy interest rate to moderate demand and return inflation to target. The fiscal authority reacts countercyclically to the pickup in real activity by reducing general transfers to households, temporarily improving the fiscal balance.

In the short run, the immediate increase in the demand for investment slightly outpaces the rise in saving, which also exerts persistent upward pressure on the real interest rate. Higher real interest rates raise the user cost of capital and thereby moderate investment demand, as well as entice households to temporarily reduces consumption and increase saving. However, in the long run, the increase in household income raises saving by more than the demand for investment, and there is small reduction in the real interest rate.

In the case of increased competition in the tradable goods sector, the fall in the relative price of tradable intermediate goods creates pressure for the real effective exchange rate to appreciate in the long run. However, in the case of increased competition in the nontradable goods sector, the reduction in the relative price of domestic nontradable intermediate goods creates pressure for the real effective exchange rate to depreciate in the long run. 
Figure 27:

Permanent Increase in Competition that Decreases the Intermediate Goods Price Markup Effects in United States

Percent or percentage point deviation from steady-state baseline

(Horizontal axis is in years: $L R=$ Long Run)

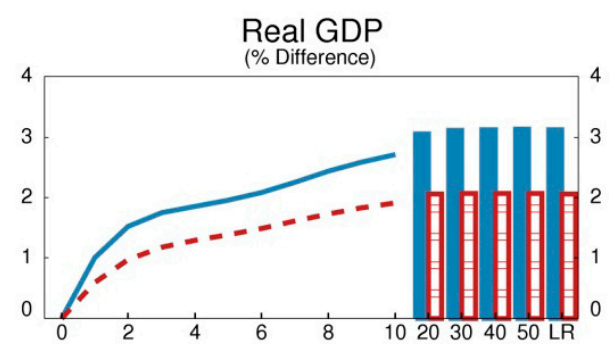

Real Private Consumption

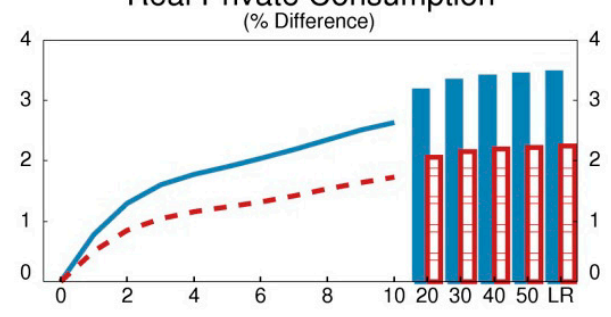

CPI Inflation

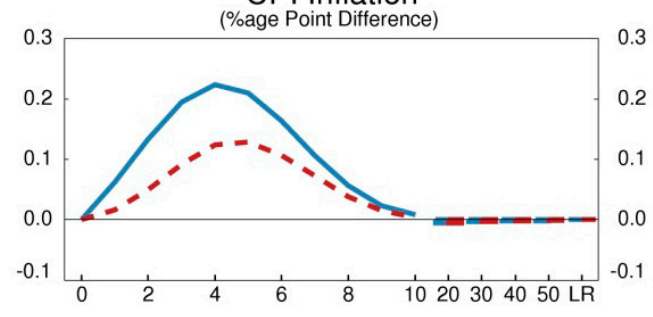

Capital Stock

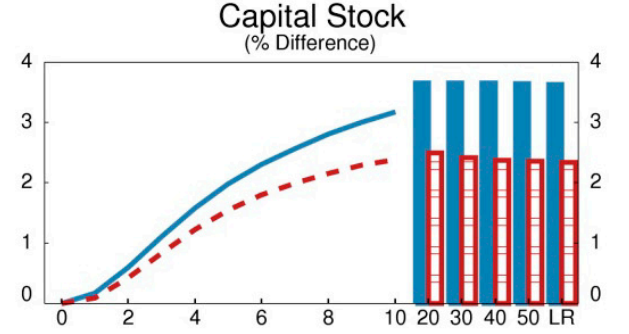

Current Account/GDP

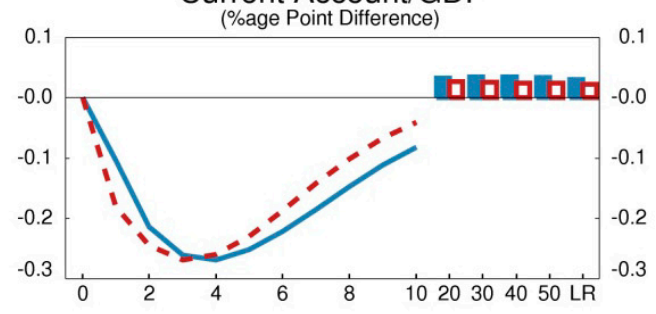

Relative Price of Goods In Nontradable, Tradable Sectors

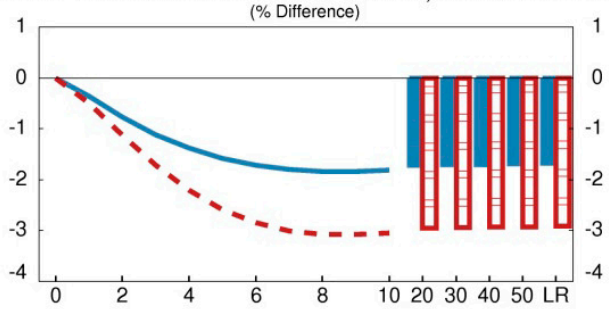

Real Private Investment
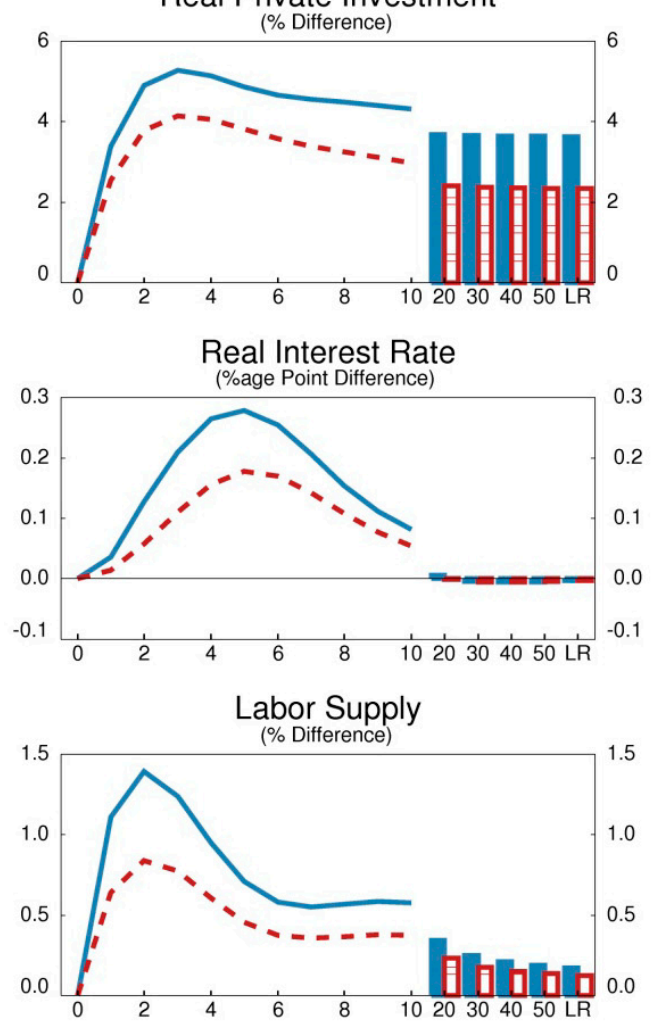

Real Effective Exchange Rate

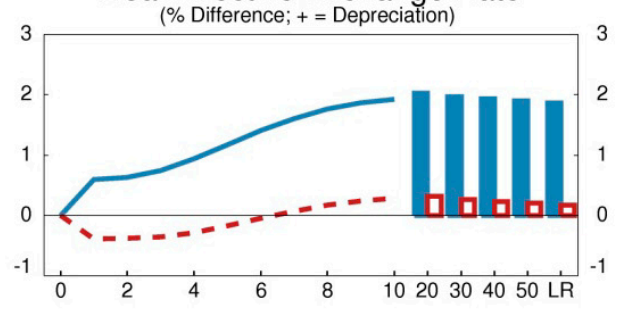




\section{Properties of International Shocks}

This section presents the effects of two simulations that are related to the external sector of the United States. The first deals with the position of the United States in global financial markets, while the second examines the international effects from an increase in U.S. tariffs.

\section{A. Temporary Increase in Sovereign Risk}

Figure 28 shows the effects of a temporary but persistent 100 basis point increase in the risk premia associated with sovereign debt obligations and other dollar-denominated assets. In other words, investors must be given higher returns to hold U.S. assets. Real GDP falls by just over $1 / 4$ percent because of a fall in domestic demand in the short and medium run, while inflation falls more modestly, and the dollar depreciates by almost $1 \frac{1}{2}$ percent.

Business investment declines due to the increase in the user cost of capital, resulting from higher real interest rates. The increase in costs reduces profitability, and hence the stream of future dividends falls, lowering household wealth. Higher costs also induce firms to scale back production and labor demand slightly, and wages post moderate declines. The impact on employment in the tradable goods sector is positive in the short run because of the increase in foreign demand resulting from the currency depreciation, while employment falls in the nontradable goods sector. Lower wealth and slightly lower labor income lead households to reduce consumption.

Weaker demand conditions lead to a mild decline in inflation, so the U.S. monetary authority lowers the nominal policy interest rate to return inflation to target. However, market interest rates are well above baseline since confidence in U.S. assets is low.

Loss of confidence in U.S. assets results in a depreciation of the real effective exchange rate. The resulting decline in the foreign currency price of U.S. exports increases demand for U.S. goods. Imports fall due to the fall in domestic demand and the depreciation. Consequently, the current account improves in the short run.

The increase in the sovereign risk premium directly increases debt-servicing costs, driving up the fiscal deficit. In the medium term, fiscal balance is restored by lowering general transfers to households. 
Figure 28:

Temporary Increase in Sovereign Risk

Effects in United States

Percent or percentage point deviation from steady-state baseline

(Horizontal axis is in years: $L R=$ Long Run)

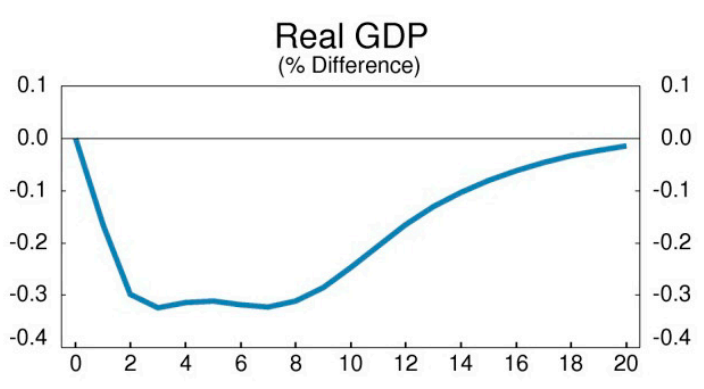

Real Private Consumption

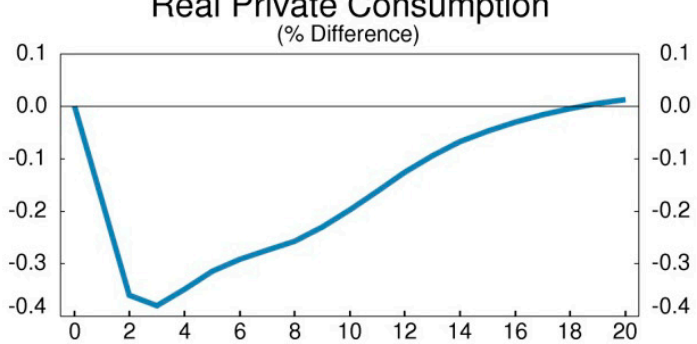

Real Exports

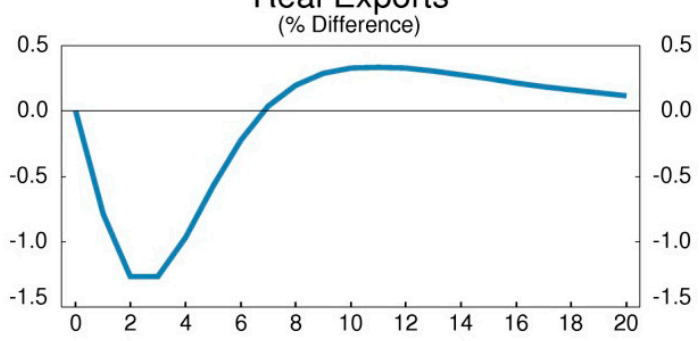

CPI Inflation

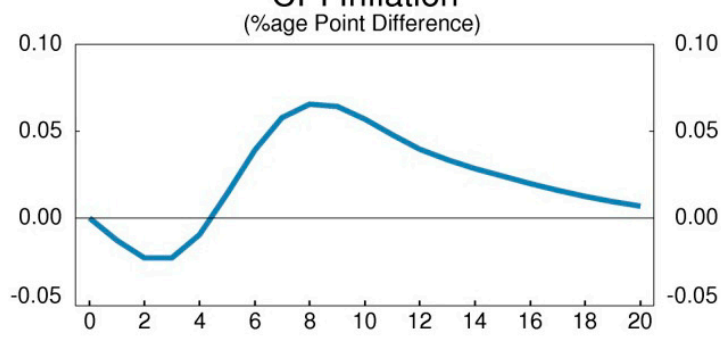

Trade Balance _, Current Account - -

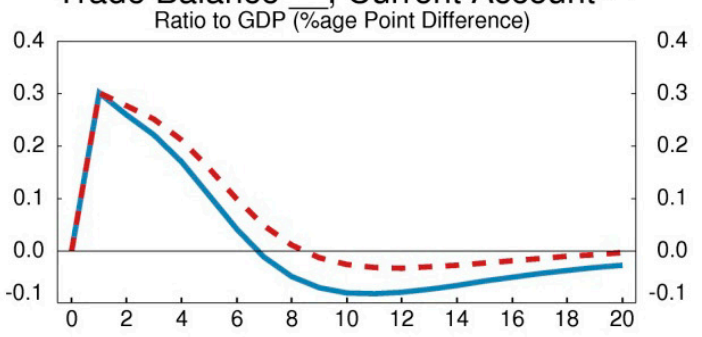

Government Surplus/GDP

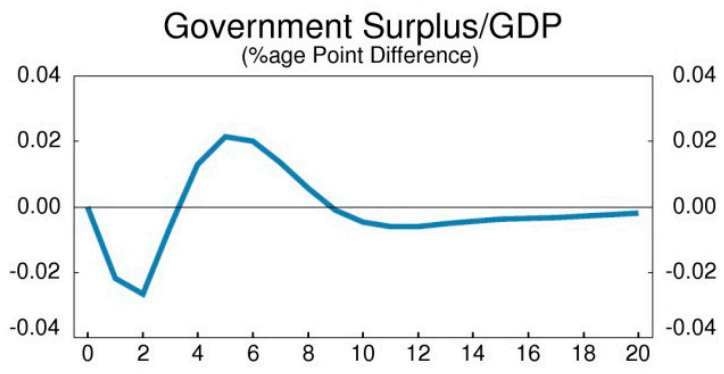

Real Private Investment

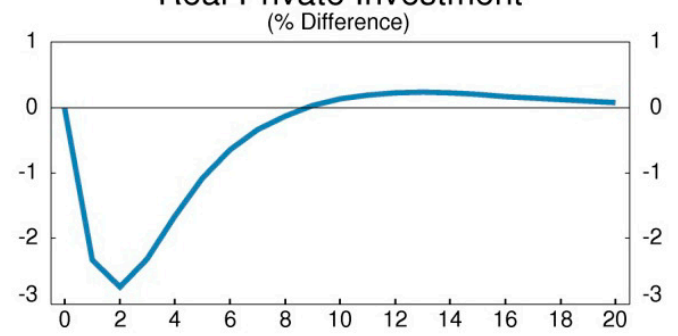

Real Imports

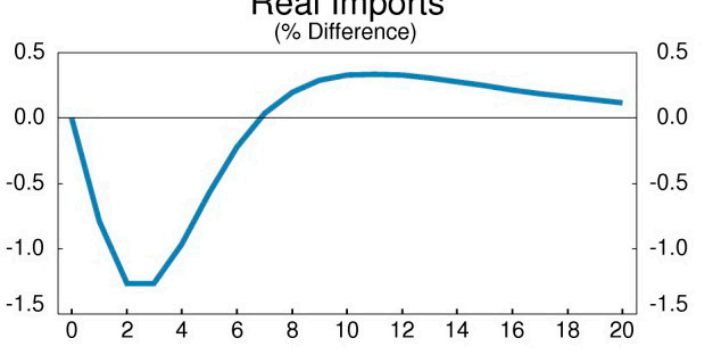

Int. Rates: Nominal _ ; Real - -; Policy ...

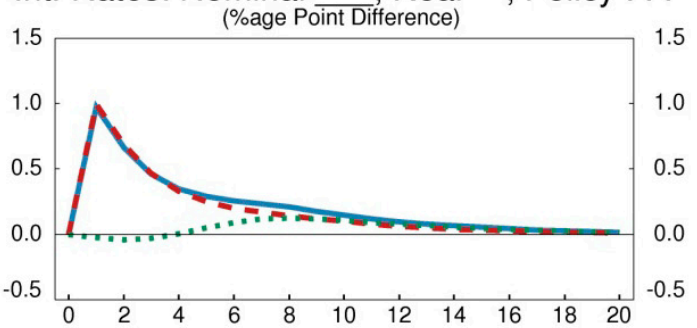

Real Effective Exchange Rate

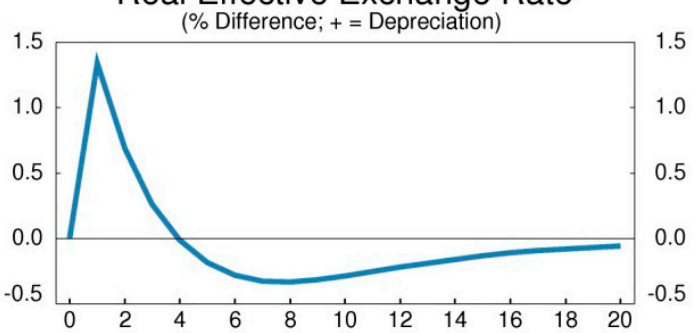




\section{B. Permanent Increase in Tariffs}

Figure 29 shows the effects of a permanent, ten percentage point increase in U.S. tariffs on imports from all other regions. There is a permanent decrease in the level of real GDP of around 1 percent. Inflation increases marginally in the short run, but quickly returns to baseline.

Income from tariffs is distributed to households via general transfers, which increases private consumption. Since tariffs raise the domestic price of imports, import volumes decline. With the United States importing less, they also do not need to export as much to maintain their desired level of net foreign assets. This leads to a real appreciation that moderates foreign demand for U.S. goods. Lower demand for final goods production in the United States means firms require less capital, and business investment declines in the long run.

While the imposition of tariffs leads to significant adjustment in the real effective exchange rate, imports, and exports, the net impact on the current account is small, with only a tiny permanent deterioration. Initially, inflation rises due to the increase in import prices from the imposition of the tariff. However, lower production leads to a decline in demand for labor and a fall in wages, thus also marginal costs. This eventually leads to a small reduction in inflation. Although monetary policy tightens temporarily when the tariff is first imposed, monetary policy is quickly relaxed, and the short-term interest rate declines. The net effect on fiscal policy is minor because the extra revenue coming from tariffs is redistributed to households via higher transfers.

A unilateral U.S. tariff increase has international repercussions. These are transmitted through exchange rates and trade linkages, as shown in Figure 30. Overall, the effect is to reduce real GDP in the rest of the world, by roughly the same amount as in the United States, if the relative sizes of the two regions are considered - the effects in the rest of the world are roughly $1 / 3$ the size of those in the United States, and the rest of the world is roughly three times larger the than the United States in terms of economic size. 
Figure 29:

Increase in US Tariffs on All Regions

Effects in United States

Percent or percentage point deviation from steady-state baseline

(Horizontal axis is in years: LR = Long Run)
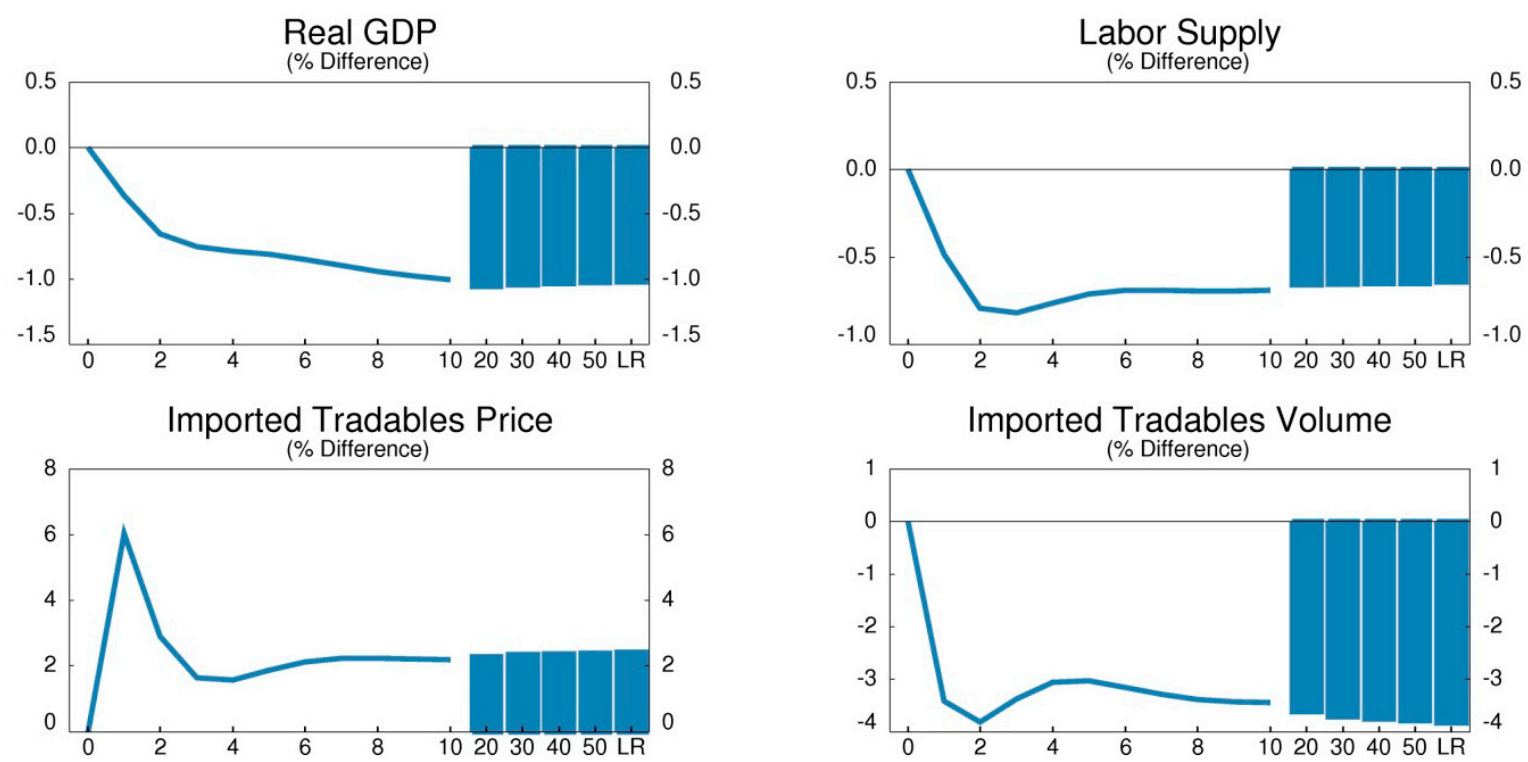

Real Private Consumption

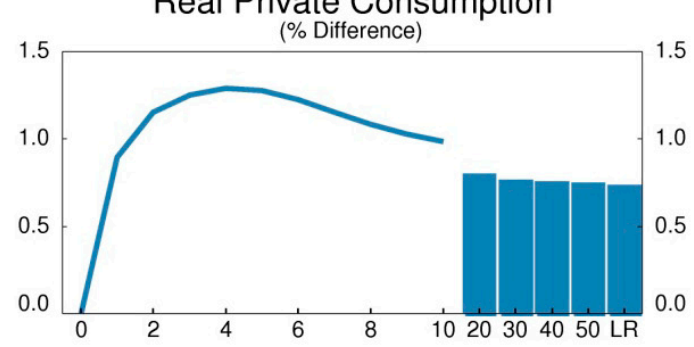

Real Private Investment

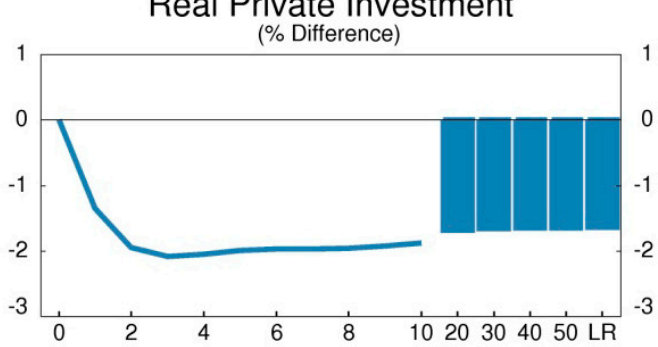

CPI Inflation

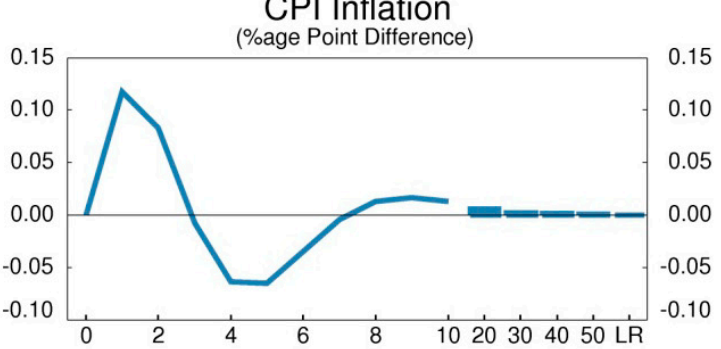

Real Interest Rate

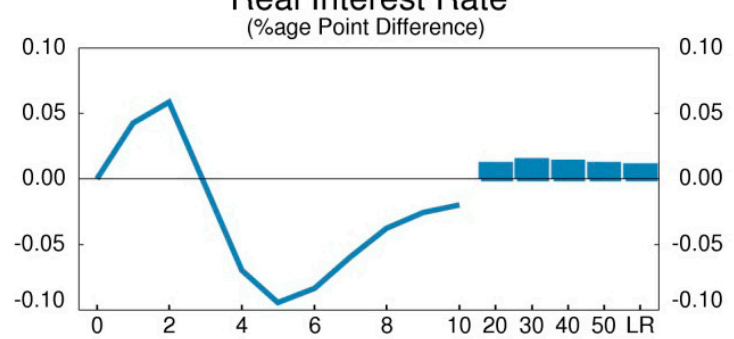

Current Account/GDP

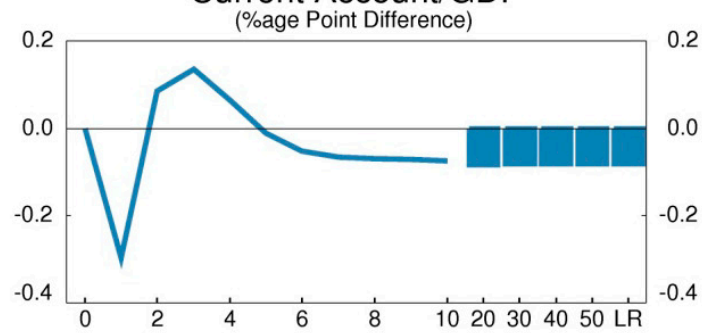

Real Effective Exchange Rate

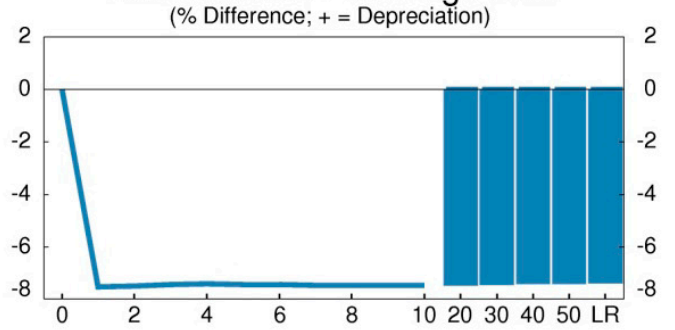


Figure 30:

Increase in US Tariffs on All Regions

Effects in the Rest of the World

Percent or percentage point deviation from steady-state baseline

(Horizontal axis is in years: $L R=$ Long Run)
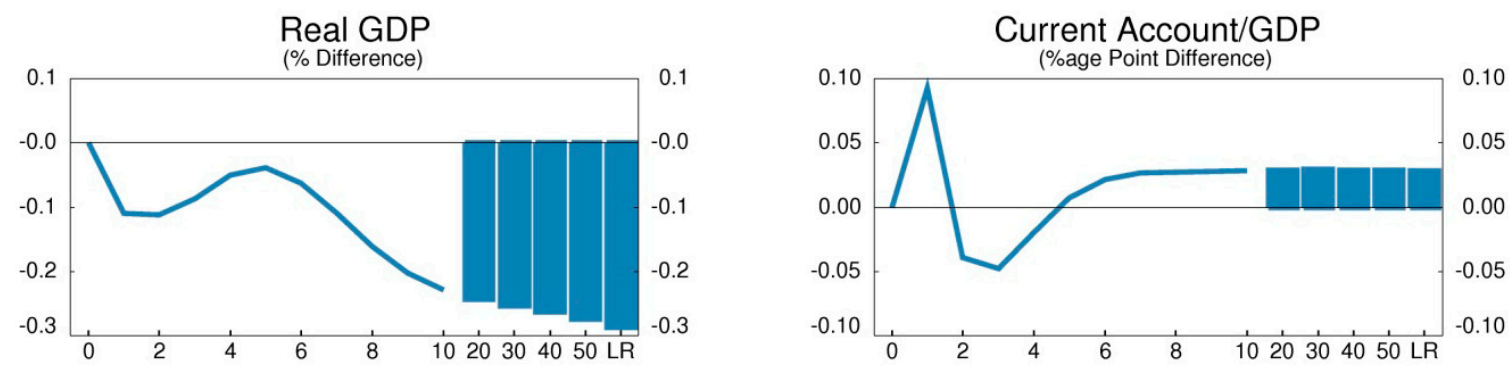

Trade Balance/GDP
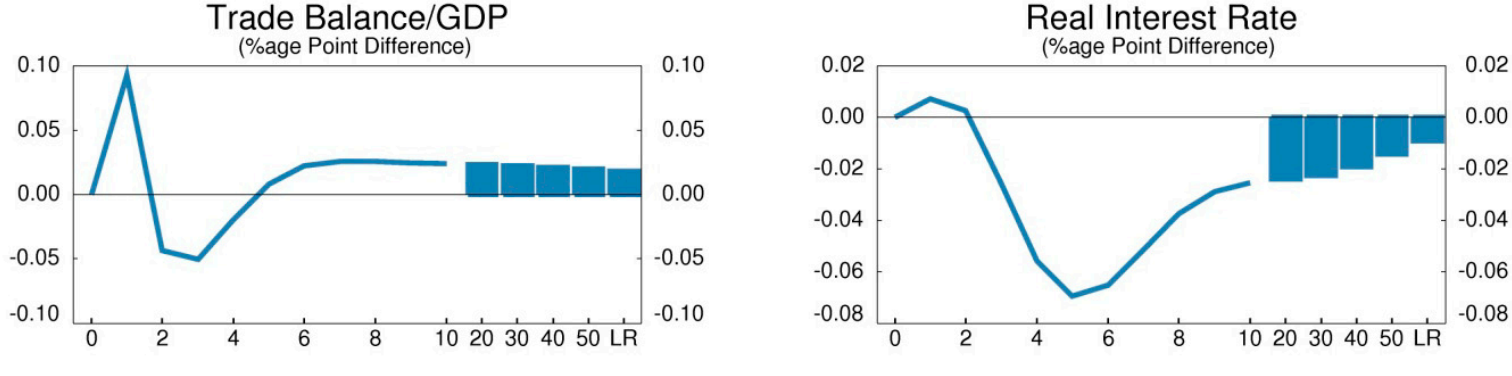

CPI Inflation

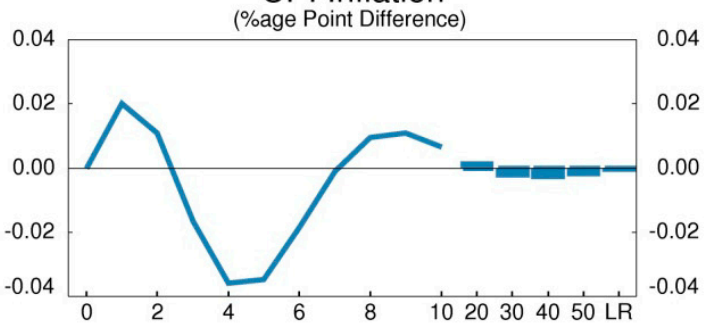

Real Effective Exchange Rate

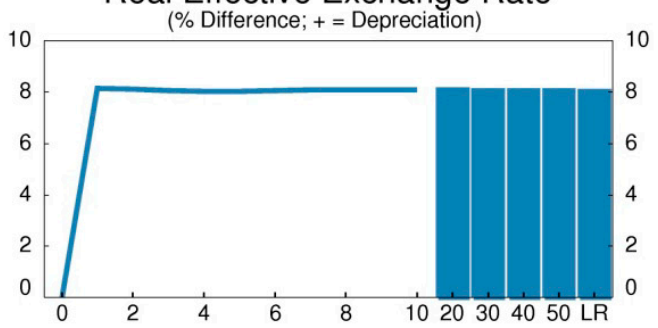




\section{REFERENCES}

Bernanke, B.S., M. Gertler, and S. Gilchrist (1999), "The Financial Accelerator in a Quantitative Business Cycle Framework," in: John B. Taylor and Michael Woodford, eds., Handbook of Macroeconomics, Volume 1C. Amsterdam: Elsevier.

Blanchard, O. (1985), "Debt, Deficits, and Finite Horizons", Journal of Political Economy, Vol. 93, pp. 223-247.

Coenen, G., C. Erceg, C. Freedman, D. Furceri, M. Kumhof, R. Lalonde, D. Laxton, J. Lindé, A. Mourougane, D. Muir, S. Mursula, J. Roberts, W. Roeger, C. de Resende, S. Snudden, M. Trabandt, J. in't Veld (2010), "Effects of Fiscal Stimulus in Structural Models, ” IMF Working Paper Series, WP/10/73, available at http://www.imf.org/external/pubs/cat/longres.cfm?sk=23671.0

Kumhof, M. and D. Laxton (2007), "A Party Without a Hangover? On the Effects of U.S. Fiscal Deficits" IMF Working Paper Series, WP/07/202, available at http://www.imf.org/external/pubs/ft/wp/2007/wp07202.pdf

Kumhof, M. and D. Laxton (2009a), "Simple, Implementable Fiscal Policy Rules," IMF Working Paper Series, WP/09/76 (April 2009), available at http://www.imf.org/external/pubs/ft/wp/2009/wp0976.pdf

Kumhof, M. and D. Laxton (2009b), "Fiscal Deficits and Current Account Deficits," IMF Working Paper Series, WP/09/237, available at http://www.imf.org/external/pubs/ft/wp/2009/wp09237.pdf

Kumhof, M., D. Laxton, D. Muir and S. Mursula (2010), “The Global Integrated Monetary Fiscal Model (GIMF) - Theoretical Structure", IMF Working Paper Series, WP/10/34, available at http://www.imf.org/external/pubs/cat/longres.cfm?sk=23615.0 